\title{
ZUSGS
}

Report to Congress-

\section{Continuing Progress Toward a National Assessment of Water Availability and Use}

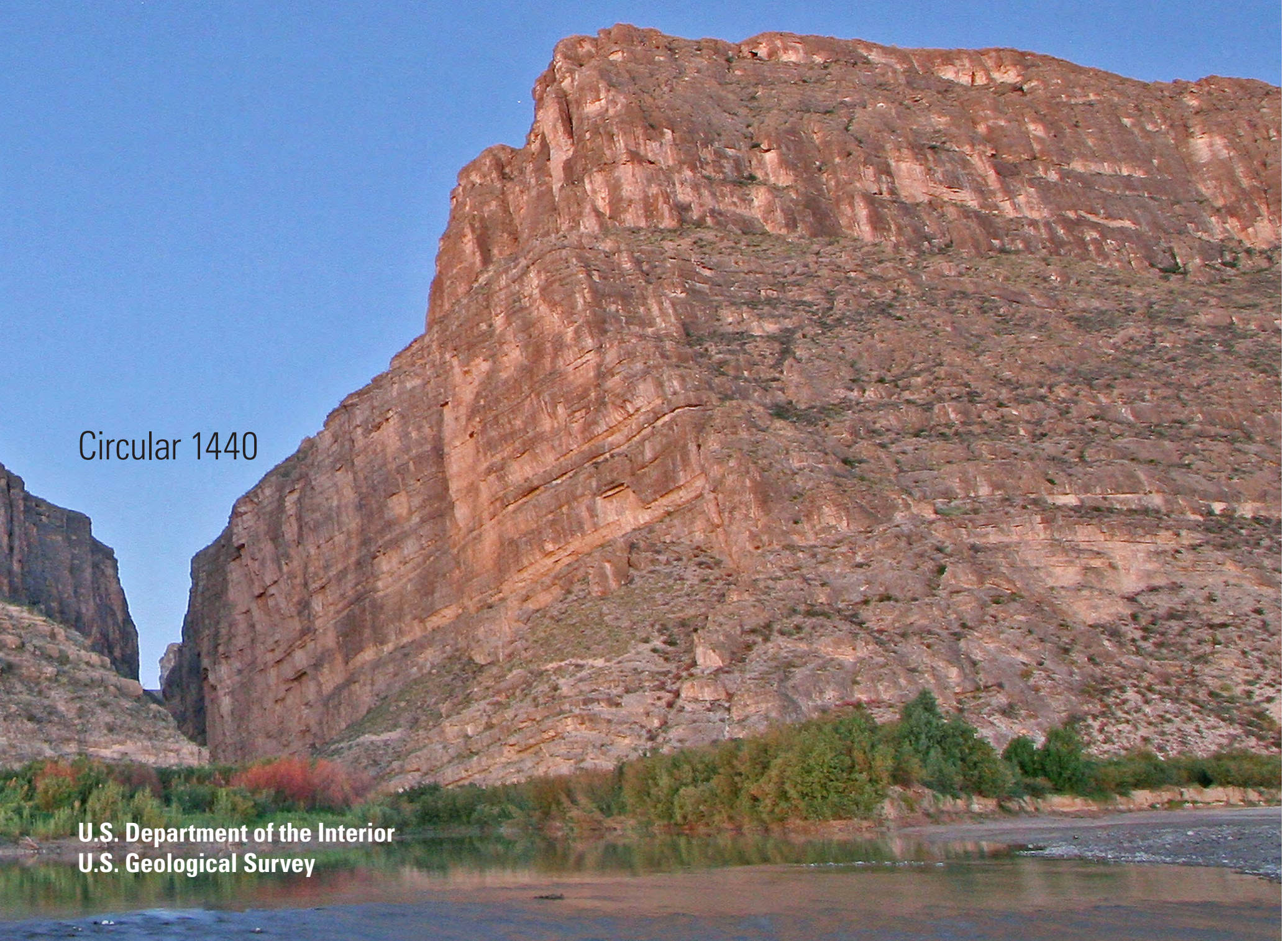




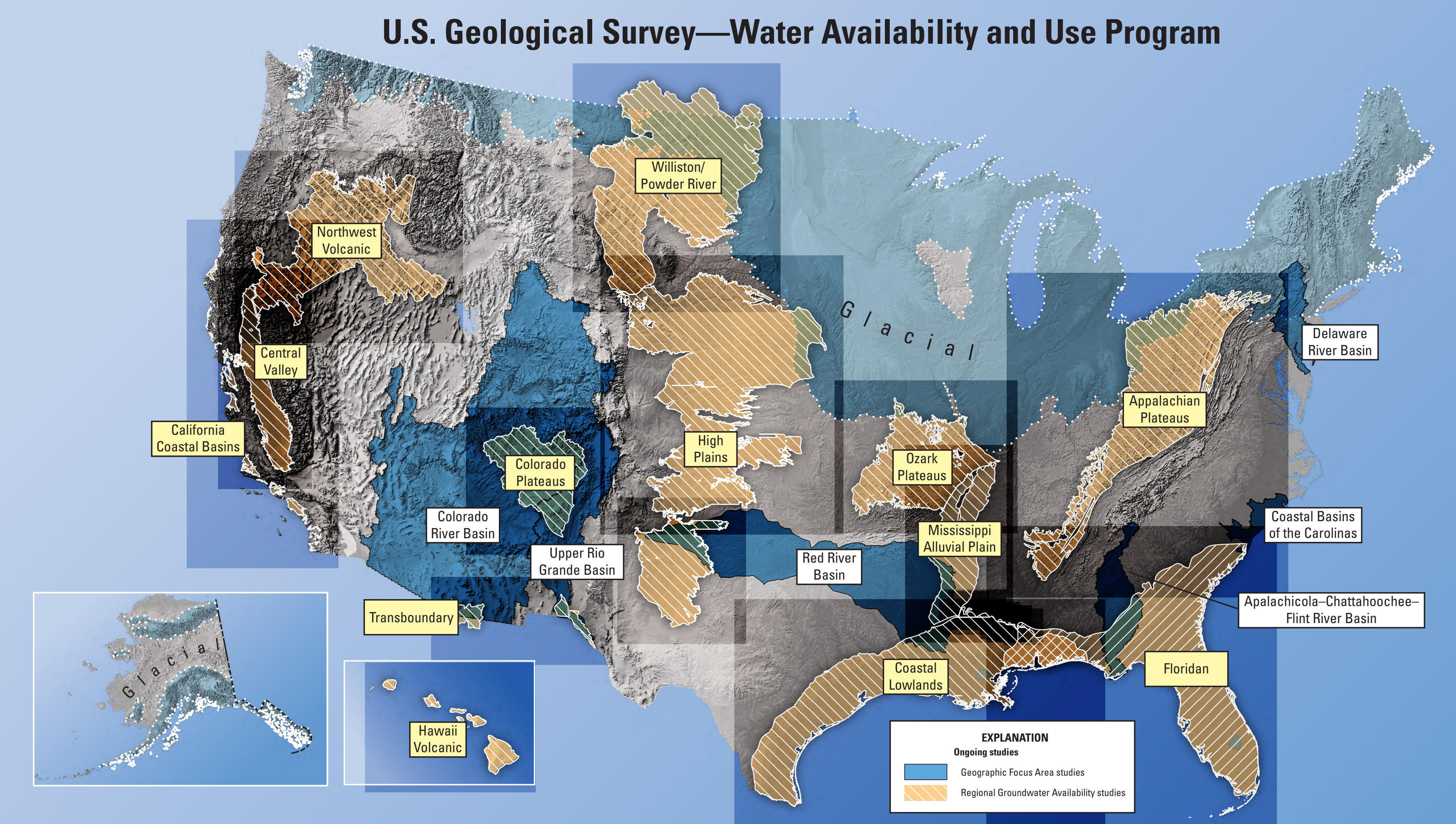

O N G O I N G N A T I O N W I D E S S U D I E S

Estimated
Streamflow




\section{Report to Congress-}

\section{Continuing Progress Toward a National Assessment of Water Availability and Use}

By Eric J. Evenson, Sonya A. Jones, Nancy L. Barber, Paul M. Barlow, David L. Blodgett, Breton W. Bruce, Kyle Douglas-Mankin, William H. Farmer, Jeffrey M. Fischer, William B. Hughes, Jonathan G. Kennen, Julie E. Kiang, Molly A. Maupin, Howard W. Reeves, Gabriel B. Senay, Jennifer S. Stanton, Chad R. Wagner, and Jennifer T. Wilson

Circular 1440 


\title{
U.S. Department of the Interior \\ RYAN K. ZINKE, Secretary
}

\author{
U.S. Geological Survey \\ James F. Reilly II, Director
}

U.S. Geological Survey, Reston, Virginia: 2018

For more information on the USGS - the Federal source for science about the Earth, its natural and living resources, natural hazards, and the environment-visit https://www.usgs.gov or call 1-888-ASK-USGS.

For an overview of USGS information products, including maps, imagery, and publications,

visit https://store.usgs.gov.

Any use of trade, firm, or product names is for descriptive purposes only and does not imply endorsement by the U.S. Government.

Although this information product, for the most part, is in the public domain, it also may contain copyrighted materials as noted in the text. Permission to reproduce copyrighted items must be secured from the copyright owner.

Suggested citation:

Evenson, E.J., Jones, S.A., Barber, N.L., Barlow, P.M., Blodgett, D.L., Bruce, B.W., Douglas-Mankin, K., Farmer, W.H., Fischer, J.M., Hughes, W.B., Kennen, J.G., Kiang, J.E., Maupin, M.A., Reeves, H.W., Senay, G.B., Stanton, J.S., Wagner, C.R., and Wilson, J.T., 2018, Continuing progress toward a national assessment of water availability and use: U.S. Geological Survey Circular 1440, 64 p., https://doi.org/10.3133/cir1440.

ISSN 1067-084X (print)

ISSN 2330-5703 (online)

ISBN 978-1-4113-4229-3 


\section{About This Report}

This report is the second in a series of reports to the U.S. Congress on the progress toward a National Assessment of Water Availability and Use (also known as the USGS National Water Census). These reports are required by the SECURE Water Act (P.L. 111-11, Section 9508 (d)) (42 USC 10368). The first report, "Progress toward establishing a national assessment of water availability and use, U.S. Geological Survey Circular 1384" (Alley and others, 2013), was delivered in March 2013. It described the initial steps taken by the U.S. Geological Survey (USGS) toward accomplishing a national census of water resources. The USGS National Water Census (the Water Census) is designed to systematically provide information that will allow resource managers to assess the supply, use, and availability of the Nation's water. This second report explains how the Water Census has progressed toward this goal from 2013 to 2017. This report describes the critical work that is underway to understand, assess, and deliver information about water availability, as well as the collaboration and coordination with other agencies and organizations that are essential for the Water Census to succeed. This report describes the on-going regional framework for presenting water-availability data through a set of geographic focus area studies and regional groundwater assessments, and the national framework for providing uniform information on water-budget components across the country through targeted topical studies. This report also documents the information management and delivery activities that are being conducted as part of the Water Census. Finally, this report describes the initiatives that are planned as part of the Water Census for the next 5 years. 


\section{Acknowledgments}

The following individuals provided helpful reviews of the draft report: Melinda Dalton and Patrick Lambert, U.S. Geological Survey; and Avra Morgan, Bureau of Reclamation. 


\section{Contents}

About This Report ............................................................................................................................

Acknowledgments ..........................................................................................................

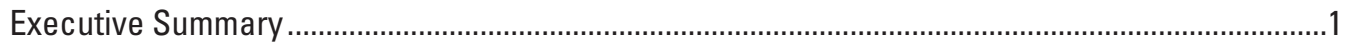

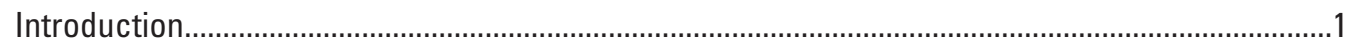

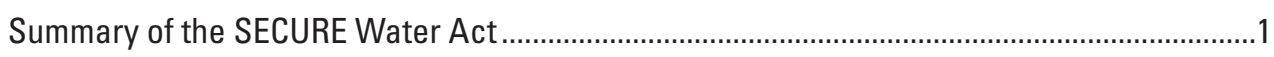

Role of Other Federal Agencies in Studies of Water Availability and Use..............................

U.S. Bureau of Reclamation ...........................................................................................

National Oceanic and Atmospheric Administration ............................................................

U.S. Environmental Protection Agency .....................................................................

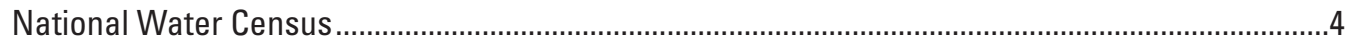

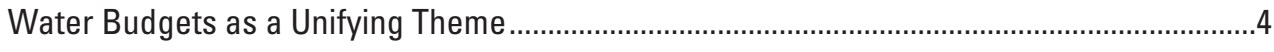

Characterizing Uncertainty .......................................................................................................

Coordination and Collaboration...............................................................................................

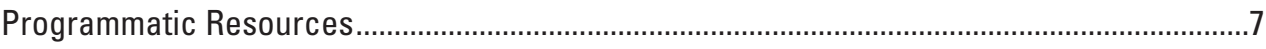

Geographic Focus Area Studies ...........................................................................................

Apalachicola-Chattahoochee-Flint River Basin (2011-15) ..................................................

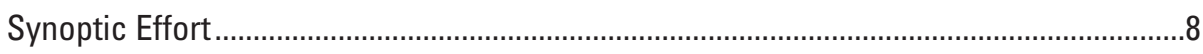

Water-Use Component............................................................................................

Simulating Surface-Water and Groundwater Flow.....................................................10

Environmental Water Component ................................................................................

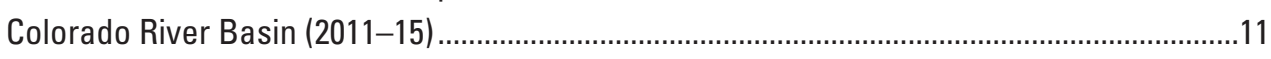

Water-Use Component..................................................................................................11

Groundwater and Base-Flow Component ..................................................................11

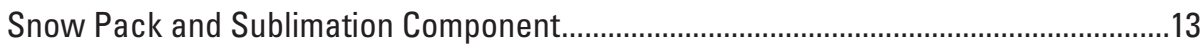

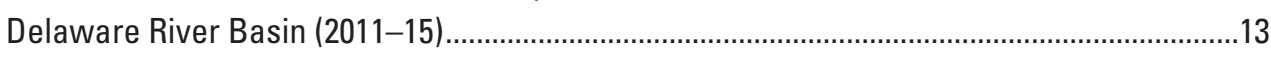

Improved Water-Use and Water-Supply Information....................................................13

Basin Hydrologic Model .......................................................................................

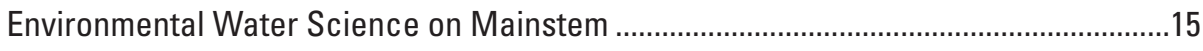

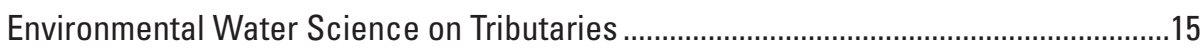

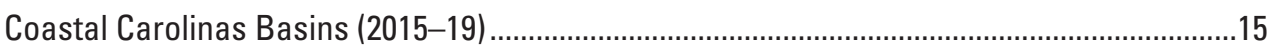

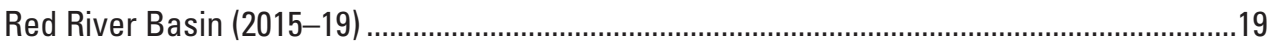

Upper Rio Grande Basin (2015-19) ..............................................................................

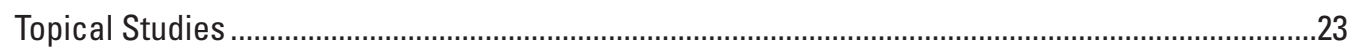

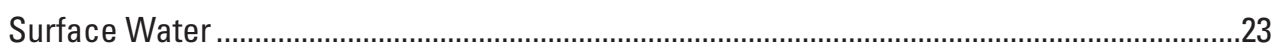

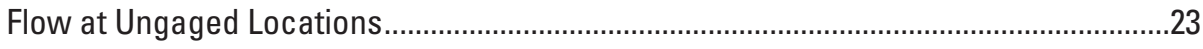

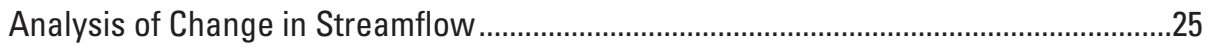

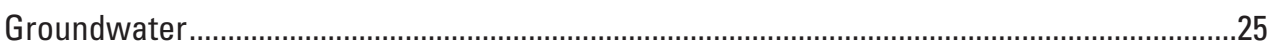

Regional Groundwater Evaluations ........................................................................25

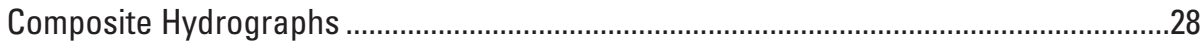

Tools for Groundwater Availability—Model Sustainability ............................................32

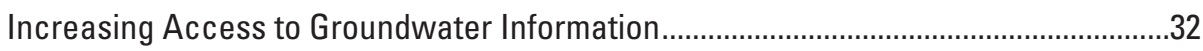

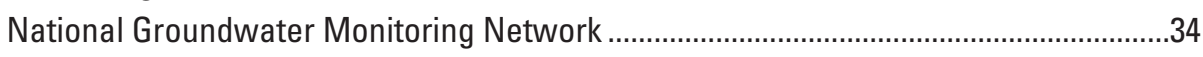

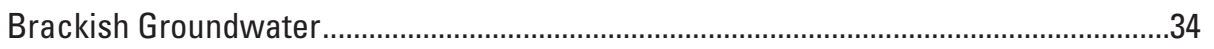




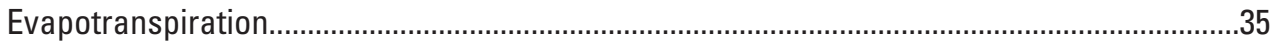

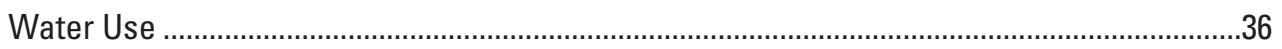

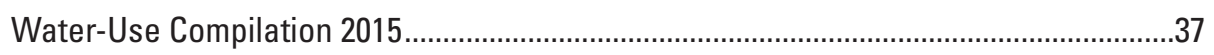

Water-Use Data and Research Program .......................................................................

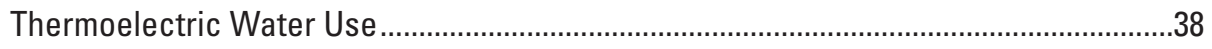

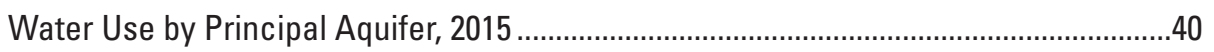

wateRuse R Programming Tools .............................................................................. 40

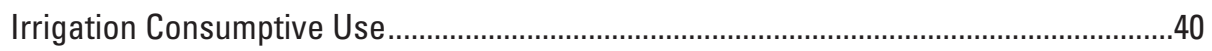

Water Use Research Funded by Cooperative Matching Funds .....................................41

Improving the Scale of Water-Use Information..........................................................41

Release of Pre-1985 Data and Statewide Totals.........................................................42

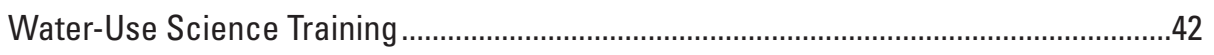

Draft Water-Use Science Strategy ..........................................................................42

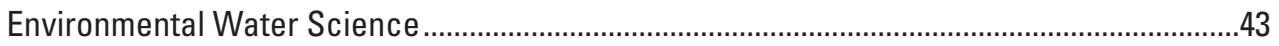

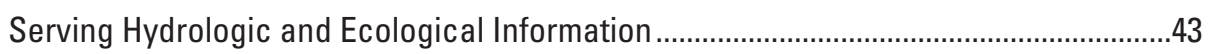

Calculation of Streamflow Metrics ............................................................................

National Classific ation of Streams ............................................................................

Aggregating Ecological Data from Multiple Agency Sources .........................................45

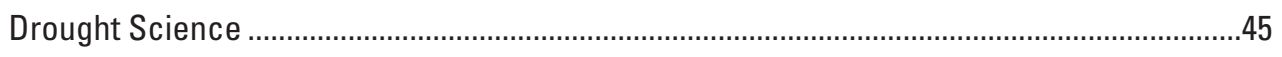

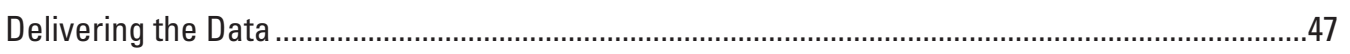

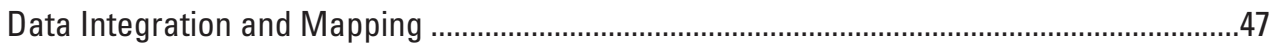

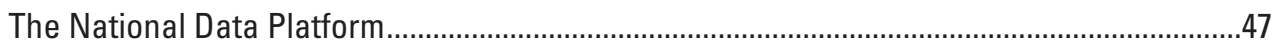

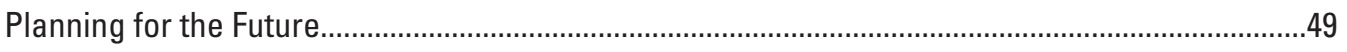

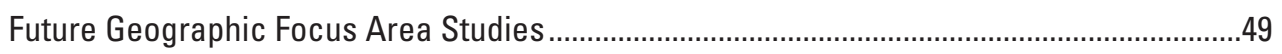

Modeling Approach..................................................................................................... 49

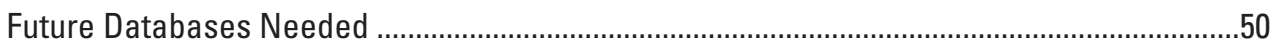

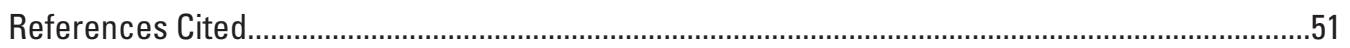

Appendix 1. Geographic Focus Area Study Publications ........................................................59

Appendix 2. Regional Groundwater Availability Study Publications ...........................................61 


\section{Figures}

1. Schematic diagram of the components of the water budget .........................................5

2. Example streamflow hydrograph with uncertainty intervals ........................................6

3. Map showing location of the Apalachic ola-Chattahoochee-Flint River Basin.................9

4. Map showing location of the Colorado River Basin, within the United States ................12

5. Map showing location of the Delaware River Basin .....................................................14

6. Map showing location of the Coastal Carolina Basins Focus Area Study ......................17

7. Screen capture of U.S. Geological Survey Coastal Carolina Basins Focus Area

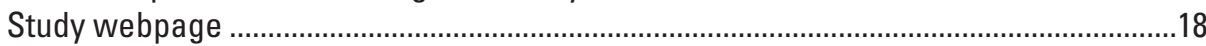

8. Map showing location of the Red River Basin.............................................................19

9. Screen capture of U.S. Geological Survey Red River Basin Focus Area Study webpage . .20

10. Map showing location of the Upper Rio Grande River Basin .........................................21

11. Screen capture of U.S. Geological Survey Upper Rio Grande River Basin Focus

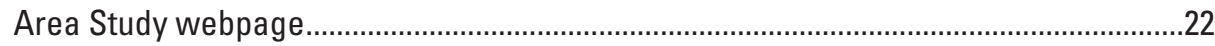

12. Schematic diagram of the U.S. Geological Survey Precipitation Runoff Modeling System

13. Diagram showing U.S. Geological Survey National Hydrologic Model-Precipitation Runoff Modeling System simulated streamflow for June 1, 2010 using the default parameters and model setup described in Regan and others, 2018 and Driscoll and others, 2017

14. Map showing Northern Atlantic Coastal Plain aquifer system cumulative groundwater withdrawals and storage depletion as percentage of total water withdrawn and percentage of total groundwater depletion from 1900 to 2013

15. Graphs showing time series of annual values of base flow and runoff at U.S. Geological Survey streamgaging stations $A, 03051000$ Tygart Valley River at Belington, W.Va.; $B, 03208500$ Russell Fork at Haysi, Va.; and C, 03118500 Nimishillen Creek at North Industry, Ohio

16. Map showing geographic distribution of trends in mean annual groundwater levels, 1984-2013 with the assumption of data independence.

17. Composite hydrograph and associated hydrologic information for the North Atlantic Coastal Plain principal aquifer, 1940-2010.

18. Composite hydrograph and associated hydrologic information for the Coastal Lowlands principal aquifer, 1975-2015.

19. Composite hydrograph and associated hydrologic information for the California Coastal Basins principal aquifer for the period 1985-2015

20. Map showing preliminary long-term average groundwater-recharge rates estimated for the glacial aquifers of the United States by use of the U.S. Geological Survey Soil-Water-Balance model as part of the USGS Glacial Aquifers Groundwater-Availability Study

21. Screen capture showing sites in New York State for which borehole-geophysical logs are available through the U.S. Geological Survey GeoLog Locator ..

22. Screen capture showing seasonal cumulative evapotranspiration anomaly for the conterminous United States, April 1-0ctober 30, 2016

23. Graphic showing states that received funds from the Water Use Data and Research Program to describe current water use and identify priorities for improving water-use data in their state. 
24. Graphic showing states that were awarded funds from the Water Use Data and Research 2016 Competitive Program to improve water-use data and research in their state

25. Graphic showing states that were awarded funds from the Water Use Data and Research 2017 Competitive Program to improve water-use data and research in their state.

26. Graphic showing hydroecological classification of 1,543 U.S. Geological Survey streamgages across the conterminous United States

27. Map showing aquatic invertebrate sampling locations aggregated from nine agency sources in the Delaware River Basin..

28. Screen capture of an accumulated water budget for a watershed in Wisconsin showing precipitation, streamflow, and evapotranspiration..... 


\title{
Continuing Progress Toward a National Assessment of Water Availability and Use
}

\author{
By Eric J. Evenson, Sonya A. Jones, Nancy L. Barber, Paul M. Barlow, David L. Blodgett, Breton W. Bruce, \\ Kyle Douglas-Mankin, William H. Farmer, Jeffrey M. Fischer, William B. Hughes, Jonathan G. Kennen, Julie \\ E. Kiang, Molly A. Maupin, Howard W. Reeves, Gabriel B. Senay, Jennifer S. Stanton, Chad R. Wagner, and \\ Jennifer T. Wilson
}

\section{Executive Summary}

The Omnibus Public Land Management Act of 2009 (Public Law 111-11) was passed into law on March 30, 2009. Subtitle F, also known as the SECURE Water Act, calls for the establishment of a "national water availability and use assessment program" within the U.S. Geological Survey (USGS). The USGS issued the first report on the program in 2013. Program progress over the period 2013-17 is reported herein to fulfill the requirement to inform Congress on implementation of the national water availability and use assessment program, also referred to as the USGS National Water Census (the Water Census).

Much work has been accomplished during 2013-17 on producing water budgets for the nation, a goal USGS outlined in its first report on program progress to Congress. The USGS has completed three geographic focus area studies and has begun three others. Work has advanced on nationwide efforts in streamflow analysis, groundwater assessment and research, evapotranspiration studies, water use, environmental water science, and drought science (inside front cover). The USGS works with Federal and non-Federal agencies, universities, and other organizations to ensure that the information can be aggregated with other types of water-availability and socioeconomic information, such as data on food and energy production. The USGS has also made great strides in measures for delivering data and information on the Water Census to stakeholders and the public.

Much work remains to be accomplished for the Nation to have a comprehensive, ongoing Water Census. In this report, the USGS lays out activities to be accomplished in the next 5 years (2017-22), based upon current funding levels. These include selecting new focus area studies, conducting hydrologic modeling to complete water budgets for the conterminous United States, expanding groundwater modeling efforts, mapping a national classification system for environmental water science, and developing an inventory of interbasin water transfers. All of these steps are necessary in order for the Water Census to achieve the goals outlined by Congress in the SECURE Water Act.

\section{Introduction}

Water has never been of greater importance to the health of our Nation, to its economies, and to the natural environment. As the United States population increases to more than 325 million, our Nation faces a growing set of water-resource challenges resulting from increased demand, fluctuations in supply, and intensified competition for limited resources. The Nation has added 10 million people to its population in the time frame of this report, 2013-17 (https://www.census.gov/ popclock/). In the face of these challenges, the need for more sophisticated information and tools to aid water-resource managers has increased as well. The U.S. Geological Survey (USGS) Water Census was created to meet that need. This report informs the reader of the progress that has been made over the last 5 years to advance our knowledge of water availability and use through improved methods of information analysis and delivery.

\section{Summary of the SECURE Water Act}

Subtitle F of the Omnibus Public Land Management Act of 2009 (Public Law (P.L.) 111-11), which was passed into law on March 30, 2009, helps address the Nation's need for water availability and use information. Also known as the SECURE Water Act, it contains substantive mandates for both the USGS and the Bureau of Reclamation (Reclamation).

Section 9508 of the SECURE Water Act calls for the establishment of a "national water availability and use assessment program" within the USGS to:

- provide a more accurate assessment of the status of the water resources of the United States;

- assist in the determination of the quantity of water that is available for beneficial uses;

- assist in the determination of the quality of the water resources of the United States;

- identify long-term trends in water availability; 
- use each long-term trend to provide a more accurate assessment of the change in the availability of water in the United States; and

- develop the basis for an improved ability to forecast the availability of water for future economic, energyproduction, and environmental uses.

The national water availability and use assessment program called for by the SECURE Water Act also is referred to as the Water Census. It is one of six major science directions identified by the USGS in 2007 in its Science Plan for the next decade (U.S. Geological Survey, 2007). Additionally, in 2016, the USGS initiated the Water Availability and Use Science Program (WAUSP) and combined all of its activities that are directly related to water availability and use in that one programmatic line item. This action was taken for the most part to accomplish the task set for the USGS by the U.S. Congress under Section 9508 of the SECURE Water Act.

Included in the SECURE Water Act is a requirement to report to Congress every five years on progress made in implementing the national water availability and use assessment program (see Box A). This report summarizes progress for the second 5-year period.

\section{Box A. Report Requested in SECURE Water Act (P.L. 111-11)}

Not later than December 31,2012, and every 5 years thereafter, the Secretary shall submit to the appropriate committees of Congress a report that provides a detailed assessment of-

1. the current availability of water resources in the United States, including-
A. historic trends and annual updates of river basin inflows and outflows;
B. surface water storage;
C. groundwater reserves; and
D. estimates of undeveloped potential resources (including saline and brackish water and wastewater);

2. significant trends affecting water availability, including each documented or projected impact to the availability of water as a result of global climate change;

3. the withdrawal and use of surface water and groundwater by various sectors, including-
A. the agricultural sector;
B. municipalities;
C. the industrial sector;
D. thermoelectric power generators; and
E. hydroelectric power generators;

4. significant trends relating to each water use sector, including significant changes in water use due to the development of new energy supplies;

5. significant water use conflicts or shortages that have occurred or are occurring; and

6. each factor that has caused, or is causing, a conflict or shortage described in paragraph (5).

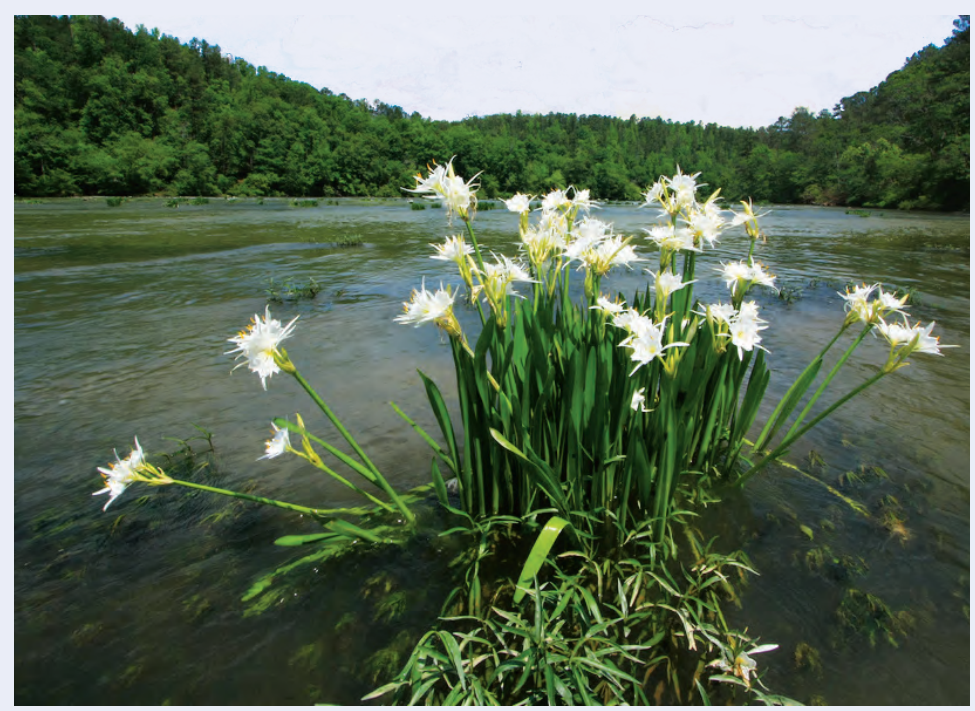

Shoal Lillies (Hymenocallis coronaria), Anthony Shoals, Broad River, Lower Broad River Wildlife Management Area, Wilkes County, Georgia. Photograph by Alan Cressler, U.S. Geological Survey 


\section{Role of Other Federal Agencies in Studies of Water Availability and Use}

The USGS works with a number of other Federal agencies on the issues of water availability and use. This collaboration is an extremely important part of serving the Nation's need for water availability and use information. In September 2007, the Subcommittee on Water Availability and Quality (at the time, a part of the Committee on Environment and Natural Resources within the U.S. Office of Science and Technology Policy [https://www.whitehouse.gov/ostp]) published "A Strategy for Federal Science and Technology to Support Water Availability and Quality in the United States" (National Science and Technology Council, 2007). Appendix I of that strategy identified 18 Federal agencies, at the bureau/service/ authority level, that play an important role in assessing water availability for the Nation. Some of these agencies are major water-resource managers and purveyors of water, such as the U.S. Army Corps of Engineers, the Bureau of Reclamation, and the Tennessee Valley Authority. Some of these agencies, such as the U.S. Department of Energy, the U.S. Environmental Protection Agency (EPA), and the U.S. Army Corps of Engineers, fill a regulatory role. Others, such as the U.S. National Park Service, the U.S. Fish and Wildlife Service, and the U.S. Forest Service, are land-management agencies also serving as stewards of the water on that land. Still others, such as the USDA Agricultural Research Service, the National Oceanic and Atmospheric Administration (NOAA), the National Aeronautics and Space Administration, and the National Science Foundation, are agencies with a science mission complementary to that of the USGS. This report provides a detailed description of the water availability work done by three of these agencies and their ongoing collaborations with the USGS.

\section{Bureau of Reclamation}

Both the USGS and Reclamation have substantive responsibilities under the Department of the Interior WaterSMART initiative. The primary USGS WaterSMART activity is the Water Census. WaterSMART activities in Reclamation include the River Basin Supply and Demand Studies; the WaterSMART Grants Program, which concentrates on water conservation and sustainability grants; and the Title XVI Program, which concentrates on water recycling and reuse projects. WaterSMART activities under the Department of the Interior require close coordination between these two agencies. There is a natural synergy between the Reclamation's River Basin Supply and Demand Studies and the USGS Geographic Focus Area Studies, which are described later in this report. The USGS and Reclamation have been active participants in the planning and execution of the studies that are of joint interest. This joint interest is directly apparent in the Colorado River Basin studies - the USGS Geographic Focus Area Study of the Colorado River Basin was designed to fulfill data needs identified during the execution of the Bureau of Reclamation River Basin Supply and Demand Study of the Colorado River. Other studies of interest to both agencies are being conducted on the Red River (of the south) Basin and the Upper Rio Grande River Basin; studies are discussed later in this report. Reclamation has been an active participant in the evaluation and selection of USGS Geographic Focus Area Studies and in the evaluation and ranking of Water Use Data and Research Cooperative Agreements. The collaboration between the USGS and Reclamation on WaterSMART is a model for Federal agencies working toward a common goal.

\section{National Oceanic and Atmospheric Administration}

NOAA delivers water information and predictions about hydroclimatic conditions from floods to droughts. The agency's analyses of snow pack and precipitation, forecasts of streamflow and warnings of flooding are indispensable with respect to saving lives and managing water resources. In recent years, NOAA has developed the National Water Model (NWM), a hydrologic model that forecasts streamflow over the entire continental United States (http://water.noaa.gov/about/ nwm). The NWM simulates the water cycle with mathematical representations of the various water-budget components and how they fit together. Models such as the NWM are powerful tools for examining near-term predictions of how water availability may change in the future. The USGS has been working directly with NOAA to enhance the scientific underpinnings of the NWM and provide ways to more effectively incorporate certain components of the hydrologic cycle, such as human water use and groundwater contributions, in the NWM. NOAA also supports research to improve climate prediction for hydrologic applications and the use of information on climate variability and change by water-resource managers.

\section{U.S. Environmental Protection Agency}

The EPA is responsible for ensuring that drinking water is safe and that watersheds, coastal oceans, and their aquatic ecosystems are protected and restored to provide healthy habitat for fish, plants, and wildlife; to support economic and recreational activities; and to ensure a healthy environment for people. To do this, the EPA administers a variety of regulatory programs pursuant to the Safe Drinking Water Act and Clean Water Act. Under these regulatory programs, the EPA collects information about water withdrawn for the purposes of public drinking water supply and the discharge of contaminants in water, including the water volume that is discharged. The databases maintained by the EPA for these purposes provide invaluable information for estimating water use associated with public water supply systems, the third largest sector of water use in the Nation, and on the volume of return flows in wastewater discharges from both municipal and industrial wastewater treatment facilities. This information is 
vital to understanding human influence on the water cycle and how people move water on the landscape. The USGS has a long-standing collaboration with the EPA on water-use science and works closely with the agency to improve methods for estimating water use.

Many other Federal agencies routinely interact with the USGS on information and issues related to water availability and use. The data, information, and collaboration of these agencies are vital to the success of the Water Census.

\section{National Water Census}

In the broadest sense, water availability has four components: (1) the need for a certain volume of water to meet the intended purpose, (2) the timing characteristics with which water is delivered, (3) the adequate quality of the water for the intended purpose, and (4) the need for water to meet both human and environmental/ecological uses. The Water Census is complex and must synthesize and report information at various spatial scales, from small watersheds to national compilations, with an emphasis on compiling and reporting this information in a way that is useful to local water managers, states, and others responsible for water management and natural-resource issues. A water-availability analysis of any given area must consider the quantity of water, the timing of water delivery, the quality of the water given the need the water is intended to satisfy, and the human and ecological needs for water in that area. The focus must be on the scientific aspects of water availability.

As the primary Federal agency responsible for scientific evaluation of the natural resources of the United States, including its water and biological resources, the USGS has the lead role in the Water Census. Because the USGS utilizes a water-budget approach to water-availability analysis, it has a unique capability to assess water-availability conditions across the Nation and report to the Congress on the questions posed in the SECURE Water Act. The USGS has an existing infrastructure that allows it to conduct a regular inventory of natural resources and water use, including water quantity, water quality, and environmental water needs. The USGS accomplishes this task through partnerships with local, State, and regional water and environmental agencies. And, as the Nation's authoritative source on water-use information, the USGS can characterize the demand of the Nation's population on the water resource.

\section{Water Budgets as a Unifying Theme}

Much of the information that makes up a Water Census is essentially the components of water budgets for watersheds and aquifers. Water budgets account for the inputs to, outputs from, and changes in the amount of water in the various components of the water cycle. They are the hydrologic equivalent of the deposits to, withdrawals from, and changes in the balance of a checking account and provide the hydrologic foundation for analysis of water availability (Healy and others, 2007). The hydrologic concept of "closing the water budget" involves balancing all components of the water budget within a given watershed area or aquifer so that the sum of the supply terms equals the sum of the demand terms. Basic components of water budgets are the supply terms (precipitation, surfacewater inflow, groundwater inflow, and human return flows to the watershed) and the demand terms (evapotranspiration, surface-water and groundwater flow out of the watershed, and human withdrawals). Other components, such as change in surface-water and groundwater storage, change in snow and ice storage, and interbasin transfers can be either supply or demand terms depending on the specific conditions (fig. 1). As with a monetary budget or checking account, knowing where, when, and how much water (or money) is "flowing" into or out of a water budget (or checking account) can illuminate how much remains for other uses (water availability) and reveal where stresses to the budget (the unpaid bills or water shortages) exist or are developing.

During the first 5 years of the Water Census (2009-13), much work has been conducted to independently estimate various water-budget components. In particular, the Water Census has worked to estimate flow in streams across the Nation where streamflow is not currently measured, evaporation from land and water surfaces and transpiration from crops and other vegetation, groundwater components in regional aquifer studies, and many different components of human water use. Precipitation, provided by the Water Census for all watersheds as a time series of data extending back to 1980 , was obtained from the Daymet datasets produced by the Oak Ridge National Laboratory of the U.S. Department of Energy at http://daymet.ornl.gov/.

The Water Census has also conducted substantial work in the development of full hydrologic cycle models. The National Hydrologic Model (NHM) (Regan and others, 2018), which simulates the full hydrologic cycle, is one example. This model is capable of providing complete-budget simulations for historical reproductions and far into the future. The importance of models like the NHM is that they provide the USGS with the capability to test the boundaries of hydrologic budget components, estimate their magnitude, simulate them in historical and current context, and forecast them under future stresses. Additionally, the historical and current simulations can be compared to actual measurements to improve understanding of the uncertainty associated with the models. This ability provides the USGS with unique insights into the natural and anthropogenic processes that influence the water budget.

The next 5 years of the Water Census (2017-22) will be devoted to demonstrating how USGS can close the water budget, thus improving the accuracy of water budgets, in major areas throughout the Nation. The USGS will also work to identify, quantify, and communicate the uncertainty associated with the various water-budget components so that users of the information understand the reliability and limitations of using this information in water-availability assessments. 


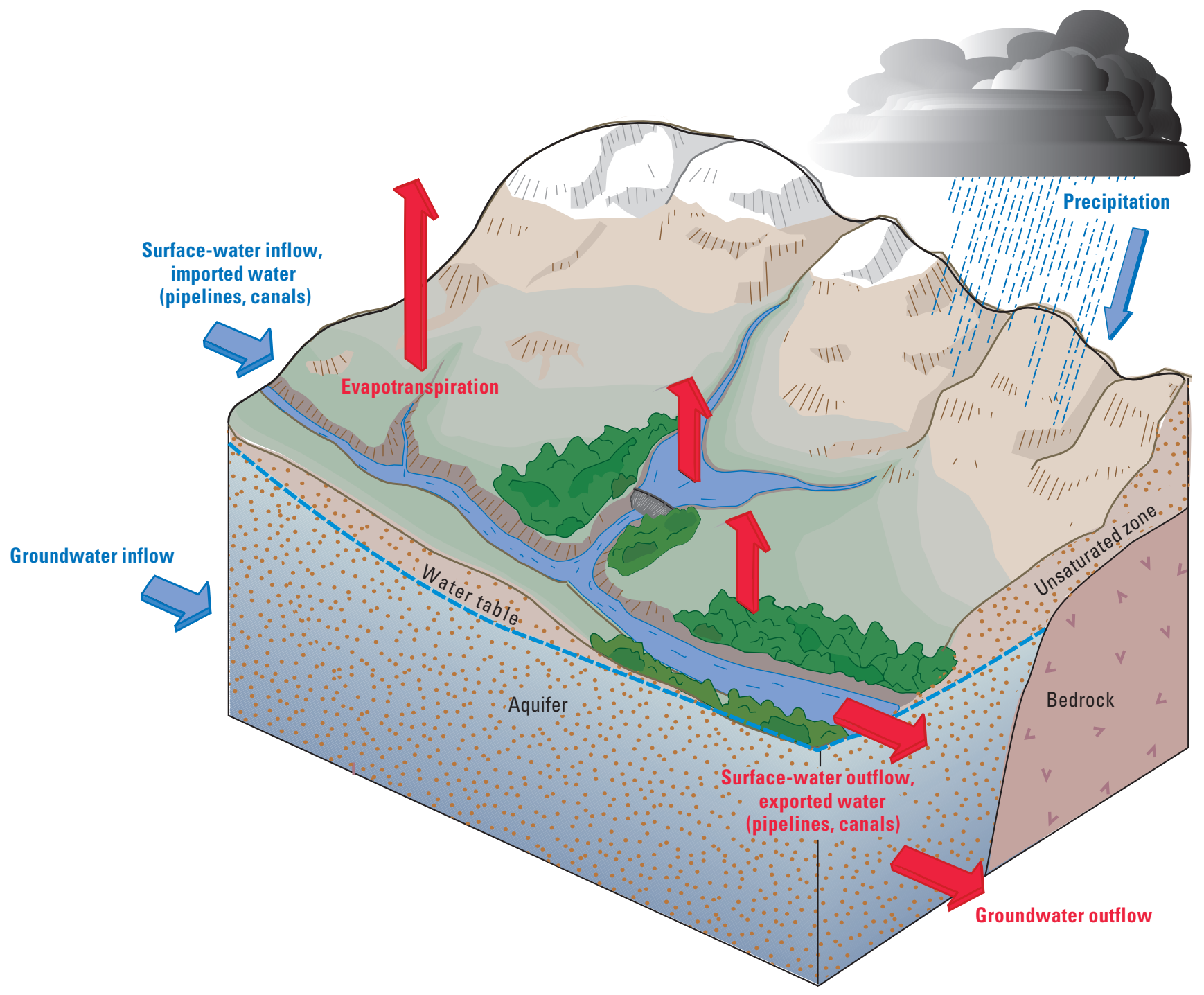

Figure 1. Components of the water budget. (Modified from Healy and others, 2007, fig. 1)

\section{Characterizing Uncertainty}

Uncertainty is an important concept in the science of water availability. Uncertainty is an inherent factor in all hydrologic data collection, estimation techniques, and simulations used in water-availability analysis. Although estimates of water availability are commonly stated as specific values, there is always a degree of uncertainty associated with the estimate and that uncertainty must be understood and communicated to those making resource-management decisions. As stated in the first report to Congress, "Errors associated with measurement techniques arise from the inability to accurately measure specific aspects of the hydrologic system, such as streamflow, the water level in a well, or soil properties that control evapotranspiration and runoff. Uncertainty arises from the inability of our data-collection networks to fully characterize the natural spatial and temporal variability associated with hydrology, geology, climate, and land use. Uncertainty also is present in hydrologic models because it is impossible to reproduce a natural hydrologic system in a model with complete accuracy." (Alley and others, 2013, p. 7). The USGS made a commitment to both quantify and communicate uncertainty associated with Water Census products, and it has made progress on that commitment.

Observational uncertainty is error associated with measurement of, in this case, specific aspects of the hydrologic cycle. One of the primary components of the hydrologic cycle is streamflow, and the Water Census has recently made efforts to quantitatively assess the uncertainty associated with individual measurements of streamflow (Kiang and others, 2016) 
and with estimates of streamflow. With regard to observational uncertainty, Kiang and others (2016) found that uncertainty is highly variable across streamgages in the Nation. In an earlier study, Kiang and others (2013) assessed the ability of the USGS streamgaging network to support estimation of streamflow statistics at ungaged locations. For each of the statistics used in this study, variability was generally greatest in the arid and semiarid central and southwestern United States. These two studies support the need for more observations of streamflow and a more complete coverage with streamgages across the Nation to reduce the uncertainty of streamflow information. And, because streamflow is generally considered one of the most accurately measured components of the hydrologic cycle, the need for more observations of other hydrologiccycle components, such as soil moisture or evapotranspiration, is implicit. The USGS is also investigating different ways of effectively communicating uncertainty associated with hydrologic observations. The USGS will implement means of communicating uncertainty with hydrologic observations in the next 5 years. For example, an estimate of streamflow at an ungaged location can be reported as a value with an associated probability of uncertainty, indicated by the range around the reported value (fig. 2).

Simulation uncertainty is the error associated with estimating hydrologic components for time periods or for locations where measurements are not available. Apart from observational uncertainty, hydrologic models can frequently introduce bias when used to produce statistics for waterresources management (Farmer and Vogel, 2016). The Water
Census has recognized a need for improved quantification of simulation uncertainty and has made strides toward quantifying uncertainty in the simulated hydrologic cycle. Building on the work of Farmer and Vogel (2016), the USGS has undertaken studies to apply a novel technique for the quantification of simulation uncertainty in daily streamflow (Bourgin, 2015; Farmer and Levin, 2017). For components of the hydrologic cycle, this technique estimates total uncertainty across all components in order to inform site-specific simulations and forecasts. Originally developed for streamflow simulation, this work is being expanded to consider uncertainty in other components of the hydrologic cycle. Effectively communicating simulation uncertainty supports water-resources management when observations are not available. The USGS will use visual means similar to those employed in figure 2 to depict model uncertainty, although the ranges associated with model uncertainty will probably be larger than those associated with observational uncertainty.

The USGS remains committed to addressing uncertainty in water-availability information. Efforts ongoing at USGS will be to quantify uncertainty of observations; to reduce uncertainty through improved observations (enhanced measurement precision and accuracy), as well as improved spatial and temporal coverage, of hydrologic variables and improved estimation techniques resulting in less model uncertainty; and to communicate uncertainty in the most useful ways possible. Through these measures, the users of Water Census wateravailability information will be fully informed of the context of the information.

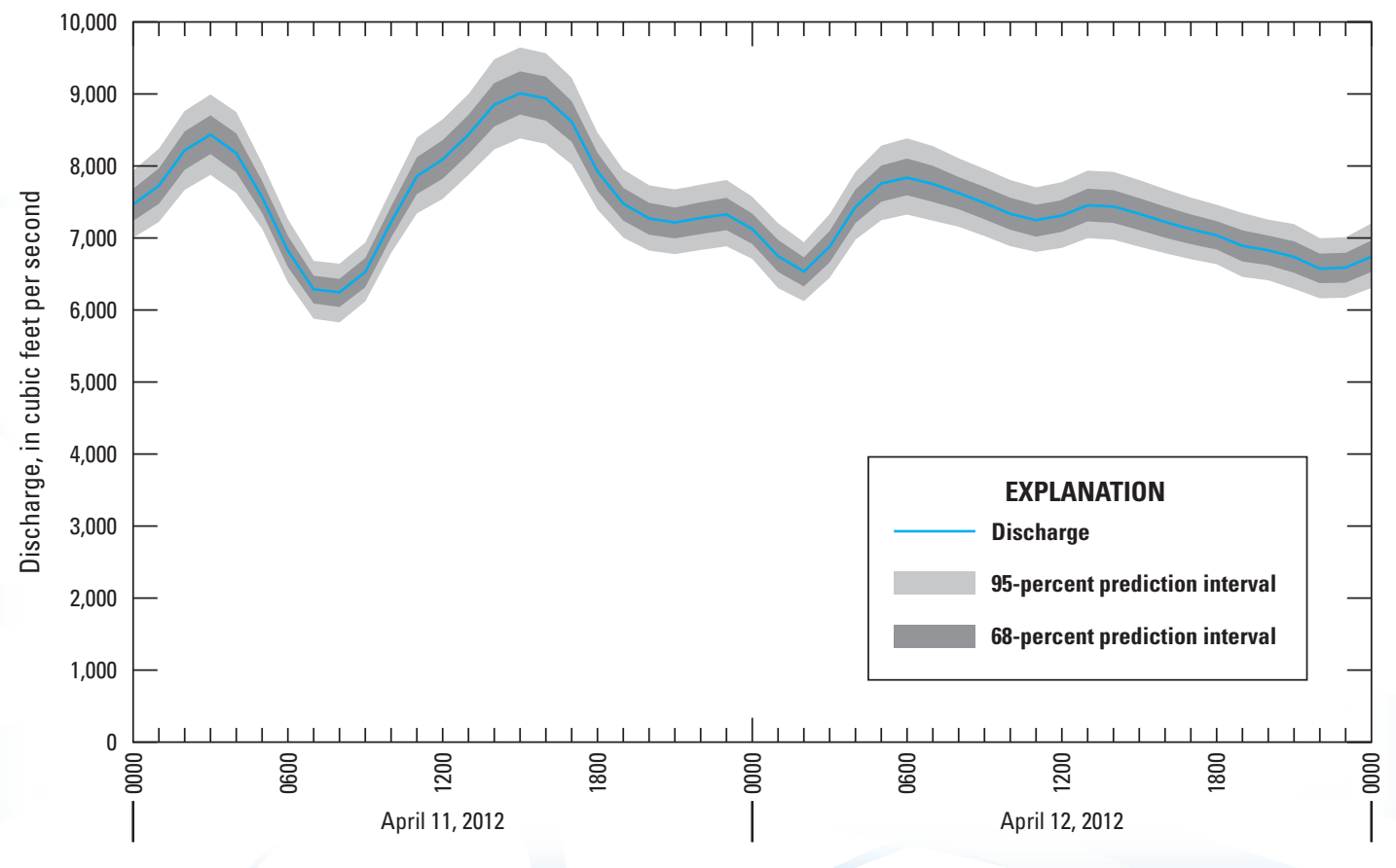

Figure 2. Example streamflow hydrograph with uncertainty intervals. 


\section{Coordination and Collaboration}

The USGS continues to receive guidance on the Water Census through the Advisory Committee on Water Information (ACWI) (https://acwi.gov/). The Water Census does this through periodic meetings to inform agencies and organizations on the progress to date and to gain advice and guidance on the types of water-availability and -use science that are most needed to answer society's questions on that topic. The Water Census has collaborated with and received input from the following agencies and organizations:

- American Water Resources Association

- American Water Works Association

- Association of Fish and Wildlife Agencies

- Association of Metropolitan Water Agencies

- Association of State Drinking Water Administrators

- Interstate Council on Water Policy

- National Ground Water Association

- The Nature Conservancy

- Sustainable Water Resources Roundtable

- Water Systems Council

- Western States Water Council

- U.S. Army Corps of Engineers

- U.S. Department of Agriculture-Natural Resource Conservation Service

- U.S. Department of Agriculture-Economic Research Service

- U.S. Department of Agriculture-National Agricultural Statistics Service

- U.S. Department of Agriculture-U.S. Forest Service

- U.S. Department of Energy —Climate Change Policy and Technology

- U.S. Environmental Protection Agency

- National Aeronautics and Space Administration

- National Oceanic and Atmospheric Administration

- Bureau of Reclamation

- U.S. Fish and Wildlife Service

The USGS also has a long history of working with State, county, regional, and Tribal agencies on water-availability studies through the Cooperative Matching Funds mechanism of the WAUSP. Cooperative Matching Funds are federally appropriated dollars used to match State, county, regional, and Tribal agency dollars to conduct assessments and research into water-availability and -use questions. In reality, the WAUSP Cooperative Matching Funds are matched at a ratio of approximately 1:2 (one Federal dollars to two non-Federal dollars) by State, county, regional, and Tribal agencies for this purpose, thereby tripling the monetary investment. The studies are conducted by the USGS, with input into the scope of work from the participating agencies. This mechanism, which was known as the Cooperative Water Program prior to fiscal year (FY) 2016, has funded hundreds of millions of dollars of work on water-availability and -use science and assessment since its inception in 1895 (Taggart, 2004). In FY 2017, the USGS allocated \$12.4 million in Federal dollars for this purpose, and these dollars were matched by $\$ 23.7$ million in non-Federal dollars. The WAUSP Cooperative Matching Funds have been used to conduct extensive assessments and research on water use; water budgets; groundwater availability, storage, and recharge; environmental water science; and evapotranspiration (https://water.usgs.gov/coop/products/availability/index.html). Starting in FY 2015 and continuing through FY 2017, as much as \$2 million of the USGS Cooperative Matching Funds were directed for water use research. Cooperative projects funded by the water use research funds typically addressed water-use and the impacts that use had on hydrology and water allocations. In the "Topical Studies" section of this report, examples of two water-use research studies are provided, demonstrating the collaborative scientific contribution that is provided by these cooperatively funded efforts with state, local, and Tribal agencies. The availability of WAUSP Cooperative Matching Funds is a major benefit to the program, to the stakeholders of the program, and to the advancement of water-availability and -use science.

\section{Programmatic Resources}

The SECURE Water Act authorized \$20 million per year for the national assessment of water availability and use (here called the Water Census) for FY 2009 through FY 2023. This report documents the activities under the Water Census from FY 2013 though FY 2017. During that period, the Congress appropriated the following funds in the respective fiscal years:

\begin{tabular}{cc}
\hline Fiscal year & Funding \\
\hline 2013 & \$6.1 million \\
2014 & $\$ 6.1$ million \\
2015 & \$11.5 million \\
2016 & $\$ 13.7$ million \\
2017 & \$14.6 million \\
\hline
\end{tabular}

These appropriations represent $\$ 52$ million of the $\$ 100$ million that the U.S. Congress authorized through the SECURE Water Act during this period. This funding provided for the activities described in this report. The USGS also leveraged existing studies and activities from ongoing USGS programs to enhance efforts toward a Water Census. The USGS engaged stakeholders to establish priorities for work in surface water, groundwater, evapotranspiration, water use, and environmental water science - all key areas for the Water Census. The studies of surface water and groundwater are fundamental to addressing items (1) and (2) in the periodic reports requested by the SECURE Water Act (see Box A), whereas evapotranspiration estimates, water use, geographic focus area studies, regional groundwater evaluations, and environmental water science are fundamental to items (3) to (6). Below, the current and completed Geographic Focus Area Studies are discussed first, and are followed by the Topical Studies. 


\section{Geographic Focus Area Studies}

The SECURE Water Act mandated an assessment every 5 years of "significant water use conflicts or shortages that have occurred or are occurring" (see Box A). The USGS interpreted this mandate as the need for information on areas of the Nation experiencing significant competition over water resources. Water-use conflicts or shortages are area-specific, and detailed information is needed to gain a full understanding of the situation. As described in USGS Circular 1348 (Alley and others, 2013), the Water Census developed the concept of Geographic Focus Area Studies (FAS) to serve this reporting purpose. Each FAS is conducted for a period of 3 years, followed by a year of report publication and products rollout. FAS serve other purposes for the Water Census as well. They (1) contribute to ongoing assessments of water availability in large watersheds with potential water-use conflicts, (2) provide opportunities to test and improve approaches to wateravailability assessment that can be transferred to other areas, and (3) inform and "ground truth" the Water Census with local information. Watershed stakeholders in each Geographic Focus Area are seeking a comprehensive technical assessment of water availability using the best available tools. The Apalachicola-Chattahoochee-Flint, Colorado, and Delaware River Basins were the first three Geographic Focus Area Studies conducted by the USGS Water Census; these studies are now completed. In 2015, an intensive process was conducted to identify three new FAS; consequently, studies were begun in the Carolina Coastal region, Red River of the south, and Upper Rio Grande River Basins. The completed FASs, including the work that has been accomplished and published as part of these studies, are discussed below, and are followed by a discussion of the ongoing FASs. Appendix 1 contains a comprehensive bibliography produced as part of the completed FAS.

An important aspect of each FAS is stakeholder involvement. During the development of each FAS work plan, the USGS hosts stakeholder meetings to gather input on the study objectives from as many stakeholders as possible. The USGS takes this input into consideration when developing the work plan for each FAS. Stakeholder meetings are also held throughout the execution of the study to provide updates on the progress and solicit input on future work that would be most applicable and useful to the stakeholders.

\section{Apalachicola-Chattahoochee-Flint River Basin (2011-15)}

The Apalachicola-Chattahoochee-Flint (ACF) River Basin covers 20,230 square miles in Georgia, southeastern Alabama, and northwestern Florida. The basin's population was 3.8 million in 2010, but many people outside the basin rely on water from the $\mathrm{ACF}$.
Litigation over appropriation of water among the three states that occupy parts of the basin has been ongoing for nearly 30 years. Most recently, a Special Master recommended denying the State of Florida's request for equitable apportionment of waters in the ACF Basin in a case against the State of Georgia that will ultimately be decided by the U.S. Supreme Court. The likelihood of litigation among the states is high, as continuing population growth in the Atlanta metropolitan area and development of agricultural irrigation in the lower Flint and Chattahoochee Basins is likely to continue to be a concern for water users downstream; for ecological needs in streams and rivers; and for the oyster fishery in Apalachicola Bay, Florida (fig. 3).

Historically, resources for resolving the interstate conflict over water availability have focused primarily on the management of large reservoirs that are operated by the U.S. Army Corps of Engineers and on flows in the major rivers in the basin. The ACF FAS provides scientific information on the many other important water-availability influences - specifically, estimates of water withdrawals and wastewater returns, groundwater pumping for irrigation, interbasin transfers, storage in unmanaged reservoirs, and effects of increases in impervious surface and climate variability on water availability. In addition, the FAS has studied flows in smaller streams that have received little attention in the past, but are critical to aquatic ecosystems throughout the basin. A complete bibliography of the ACF River Basin FAS is presented in appendix 1.

\section{Synoptic Effort}

During the first year of the study (2011), exceptional drought conditions prevailed in the lower Apalachicola-Chattahoochee-Flint and adjacent Aucilla-Suwannee-Ochlockonee River Basins during the summer months. Cumulative rainfall departures from 1981-2010 climate normals were in the range of 17 to 27 inches, providing an excellent opportunity to measure streamflow and groundwater levels under extreme dry conditions. Measurements indicated that water levels in 12 of 43 surficial aquifer wells and 128 of 312 Upper Floridan aquifer wells were at record lows. Most streamflows measured were below normal ( $<25$ th percentile), with 286 miles of streams losing flow in the downstream direction and 606 miles of streams being dry. These data are important for understanding how the hydrologic system functions under lowflow conditions and were used to calibrate surface-water and groundwater flow models. The results of the synoptic study are published in a USGS Scientific Investigations Report (Gordon and others, 2012).

\section{Water-Use Component}

Water-use estimates and water returns for the ACF Basin were compiled by category and location for calendar year 


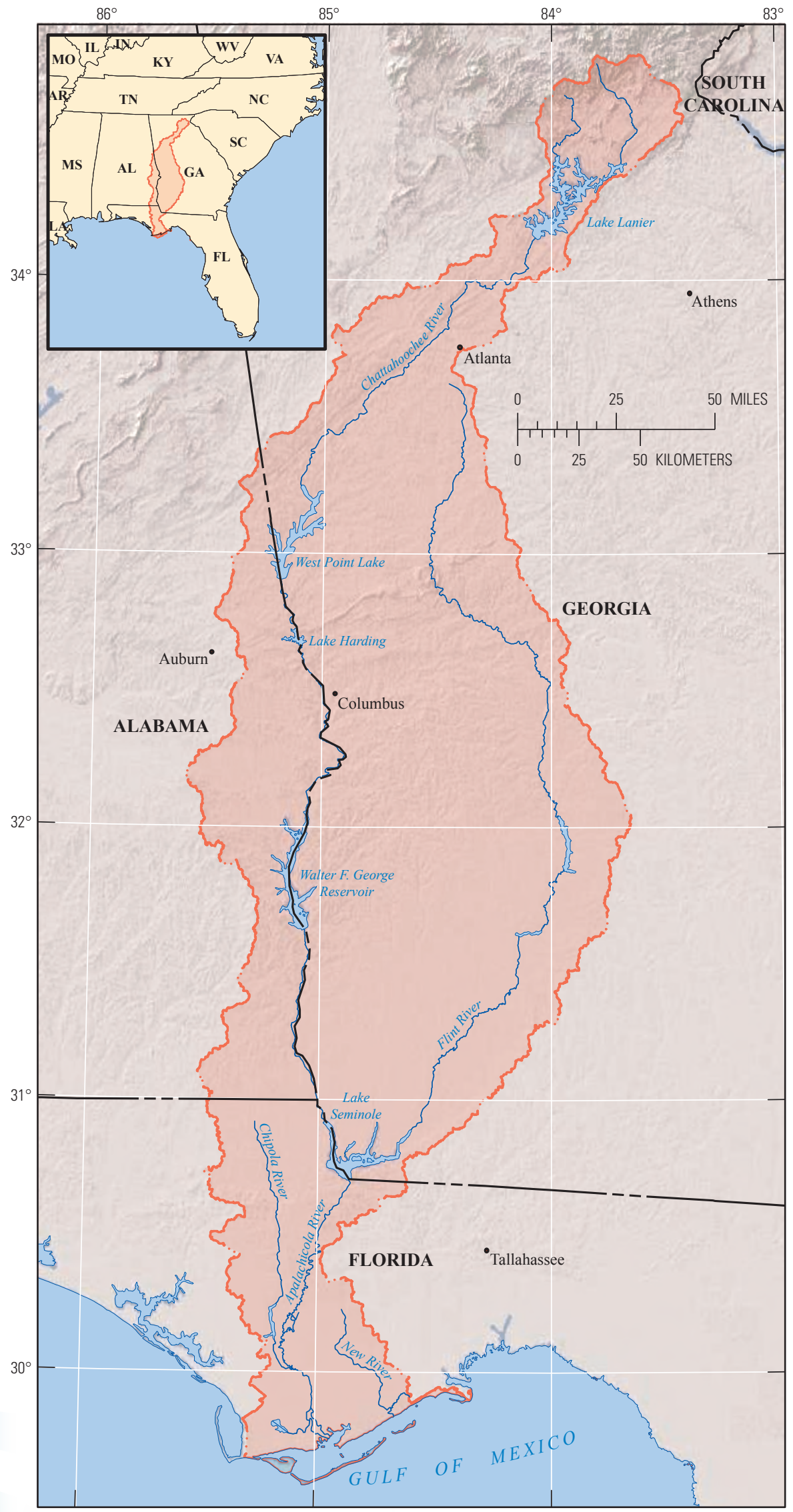

Base modified from U.S. Geological Survey 1:100,000-scale digital data
Figure 3. Location of the Apalachicola-Chattahoochee-Flint River Basin. (From Alley and others, 2013, fig. 2) 
2010. Categories included public supply, self-suppled domestic, self-supplied commercial, industrial, mining, agricultural (crop irrigation, livestock, and aquaculture), and thermoelectric-power generation use. These data were compiled at the 8-digit hydrologic unit code (HUC-8) subbasin scale and published in a USGS Scientific Investigations Report (Lawrence, 2016).

In 2010, an average of 1,645 million gallons per day (Mgal/d) was withdrawn in the ACF Basin, with about 35 percent of withdrawals derived from groundwater sources and 65 percent derived from surface water. About $564 \mathrm{Mgal} / \mathrm{d}$ (34 percent of withdrawals) was returned to streams and rivers in the basin (mostly as treated wastewater), and less than 4 percent of withdrawals was transferred outside the ACF Basin (interbasin transfers). Although population in the basin, particularly in the Atlanta metropolitan area, increased by 45 percent from 1990 to 2010, surface-water use declined during that period, most likely as a result of conservation measures. Groundwater use, in contrast, has steadily increased as a result of increases in pumping for agricultural irrigation, with spikes in use during drought years.

Agriculture is the largest water use in the ACF Basin and estimates of agricultural water use are typically complex, with high levels of uncertainty. To address this uncertainty, three different methods were tested in the ACF FAS to compare their ability to match estimates of irrigation water use derived from metered wells. These methods include (1) crop demand, (2) geostatistical methods with variography and conditional simulation, and (3) remote-sensing technology to identify irrigated lands. Results are presented in a USGS Scientific Investigations Report (Painter and others, 2015) and indicate that information on local agricultural practices and spatial and temporal distribution of irrigated lands are critical for all three methods.

\section{Simulating Surface-Water and Groundwater Flow}

The USGS evaluated hydrologic flows in the ACF Basin by using linked groundwater (MODFLOW) and surface water (Precipitation Runoff Modeling System, PRMS) models. These are tools that resource managers can use to evaluate the availability of freshwater to meet the competing needs throughout the basin. The models greatly enhance the ability to simulate the effects of groundwater pumping on streamflows under a variety of climate and water-use scenarios and help to evaluate adequate instream flow for ecological needs throughout the basin. The models are documented in USGS Scientific Investigations Reports (Jones and others, 2017; LaFontaine and others, 2017). In addition, enhancements to the PRMS were made to facilitate the incorporation of wateruse data (described in the preceding section), stream and lake flow routing, and simulation of surface-depression storage and are published in a USGS Techniques and Methods Report (Regan and LaFontaine, 2017).
The simulation results indicate that recharge to the groundwater system is much more dynamic than previously believed, with nearly all recharge occurring during winter months or infrequently during periods of intense rainfall during the remainder of the year. Streamflows simulated for 2008-12 with flow components from the linked models provided improved estimates for the warm season months, when irrigation is active, and underestimated streamflow volumes during the cool season months. The linked models indicated that groundwater storage in the Floridan aquifer in the study area declined by about 3.6 percent, and the decline is likely the result of dry conditions during the simulation period. The model was not used to simulate long-term changes in storage, but the simulated changes in groundwater storage coupled with a more realistic simulation of the dynamics of the system indicate that the model will be useful for future waterresources management.

\section{Environmental Water Component}

The environmental water project in the ACF Basin improves understanding of the ways in which changes in streamflow conditions may affect an important aspect of the health of streams and rivers - specifically, the local diversity of fishes. Many studies over the last two decades have shown correlative evidence that streams with more altered flow regimes also support diminished fish communities; however, little is known about the mechanisms underlying these patterns. By quantifying how well fishes can persist through periods of unusually low or high flows, or recover following stressful events, scientists can help managers forecast water-management effects on future diversity and abundance of fishes, enabling them to make effective resource-management decisions (Freeman and others, 2013; Peterson and Freeman, 2016).

To provide data on the mechanisms by which streamflows affect fish assemblages, the USGS completed 233 surveys of fishes at $40 \mathrm{ACF}$ sites over a period of 6 years, including years of exceptionally low and relatively high streamflows. The ACF is a useful ecological setting for studying streamflow effects on fishes not only because the basin is home to a high diversity of fishes (at least 100 native species), as well as a variety of stream types, including low-gradient, sand-dominated streams in the Coastal Plain and higher gradient, cobble-dominated streams in the Piedmont and Blue Ridge Provinces. Therefore, analyses of the survey data have focused on understanding how streamflow variation affects persistence and resiliency of fishes that have differing habitat requirements, in physically different environments.

Important findings of this work include new evidence that fishes show an increasing likelihood of loss from stream sites as seasonal streamflows dip below long-term averages, but that these losses may be balanced by species re-establishing during periods of above-average flow (Wheeler and others, 2017, 2018). However, fishes which primarily inhabit streams 
do not appear equally resilient, and populations of the same species may recover more readily in some streams than others. In particular, fishes that commonly inhabit a wide range of aquatic habitats (including lakes, wetlands, and streams), such as many sunfishes and mosquitofishes, may be more likely to re-establish at a site following local extirpation than are stream-dependent fishes, including many minnow and darter species. Additionally, populations of the same species show greater resilience to local losses in Coastal Plain streams than in higher gradient upland (Piedmont and Blue Ridge) streams. These findings imply that effective streamflowmanagement strategies for protecting biological diversity may differ depending on the types of fishes present and the physical setting.

\section{Colorado River Basin (2011-15)}

The Colorado River is about 1,450 miles long with a drainage-basin area that covers about 246,000 square miles in parts of seven states (fig. 4). Because of many factors, including that the most downstream portion of the river crosses the international border with Mexico, water management, water law, and flow regulation are a complex system involving international treaties, interstate compacts, and Supreme Court decrees. Within the United States, the water diverted from the Colorado River serves more than 30 million people, many located outside the hydrologic basin in California, Colorado, New Mexico, and Utah, and irrigates more than 4 million acres of agricultural land. Flow in the Colorado River also supports a multibillion dollar tourist and recreational industry. The Colorado River is a critical resource for a substantial portion of the mostly arid southwestern United States. Declining streamflows, increasing population, and a projected drier future climate present additional challenges to an already stressed water-delivery system.

Reclamation plays a major role in the control and distribution of surface water across the Colorado River Basin through the management of large Federal water projects like Glen Canyon Dam (Lake Powell) and Hoover Dam (Lake Mead). These and several other reservoirs and diversions throughout the basin are operated as a single system to facilitate the beneficial use of the annual runoff, which originates largely as snow melt in the Rocky Mountains. Effort is made each year to track the annual "natural" flow and monitor the consumptive surface-water use to meet litigated rights (part of what is referred to as "The Law of the River"), meet contractual obligations for water delivery, and to generate a substantial amount of hydropower for customers in the southwestern United States. In 2012, Reclamation and its partners completed a Colorado River Basin Water Supply and Demand Study (https://www.usbr.gov/lc/region/programs/crbstudy. $\mathrm{html}$ ). Early discussions with Reclamation and other stakeholders in the Colorado River Basin identified several aspects of the basin water budget that were in need of additional study and information after the Supply and Demand Study. Improved understanding of water use in the basin (especially agricultural consumptive uses); an increased understanding of snowpack development, runoff, and sublimation losses; and the relative importance of regional groundwater flow and groundwater discharge supporting streamflows were identified as primary components needing attention during the Colorado River Basin FAS. These components became the focus of the Colorado River Basin FAS. The following subsections provide a short summary of the USGS contribution to these topics. A complete bibliography of the Colorado River Basin Focus Area study is presented in appendix 1 .

\section{Water-Use Component}

The USGS is conducting a basin-specific water use study, analyzing uses by category and HUC-8, including analysis of trends, at 5-year increments from 1985 to 2010. This study will also identify all major transfers of water out of the Colorado River Basin to adjacent areas for years 2000, 2005, and 2010. Water-use information from the seven basin states is being compiled and quality-assured, and consistent water use estimates provided on surface-water diversions and withdrawals, groundwater withdrawals, and surface-water return flows. Particular emphasis will be placed on analyzing trends in water use over this 25 -year period. The water-use study presents water-withdrawal information aggregated at the HUC-8 level for the following water-use sectors: public supply, self-supplied domestic, self-supplied commercial, industrial, livestock, mining, aquaculture, irrigation, thermoelectric and hydroelectric water, and wastewater return flows. Consumptive use estimates are included in the study for irrigated agriculture and thermoelectric power generationthe only two categories of use for which USGS methods for estimating consumptive have been updated since 1995. These two water-use categories are the largest water uses nationally and in the Colorado River Basin. The study, when completed, will provide an improved understanding of the major sectors of water use and the spatial distribution of those uses within the Colorado River Basin.

\section{Groundwater and Base-Flow Component}

Historically, management of water resources in the Colorado River Basin has focused on surface water; however, surface-water flow is sustained, in part, by groundwater discharge to streams. In light of recent droughts and ongoing landscape change, groundwater and surface water must be understood and managed as a single resource. Compared with surfacewater flows, groundwater discharge to streams is difficult to measure, and is a less well understood component of the water budget. A series of studies was conducted using instream water-quality data to estimate the fraction of streamflow that is supported by groundwater discharge to streams across the 


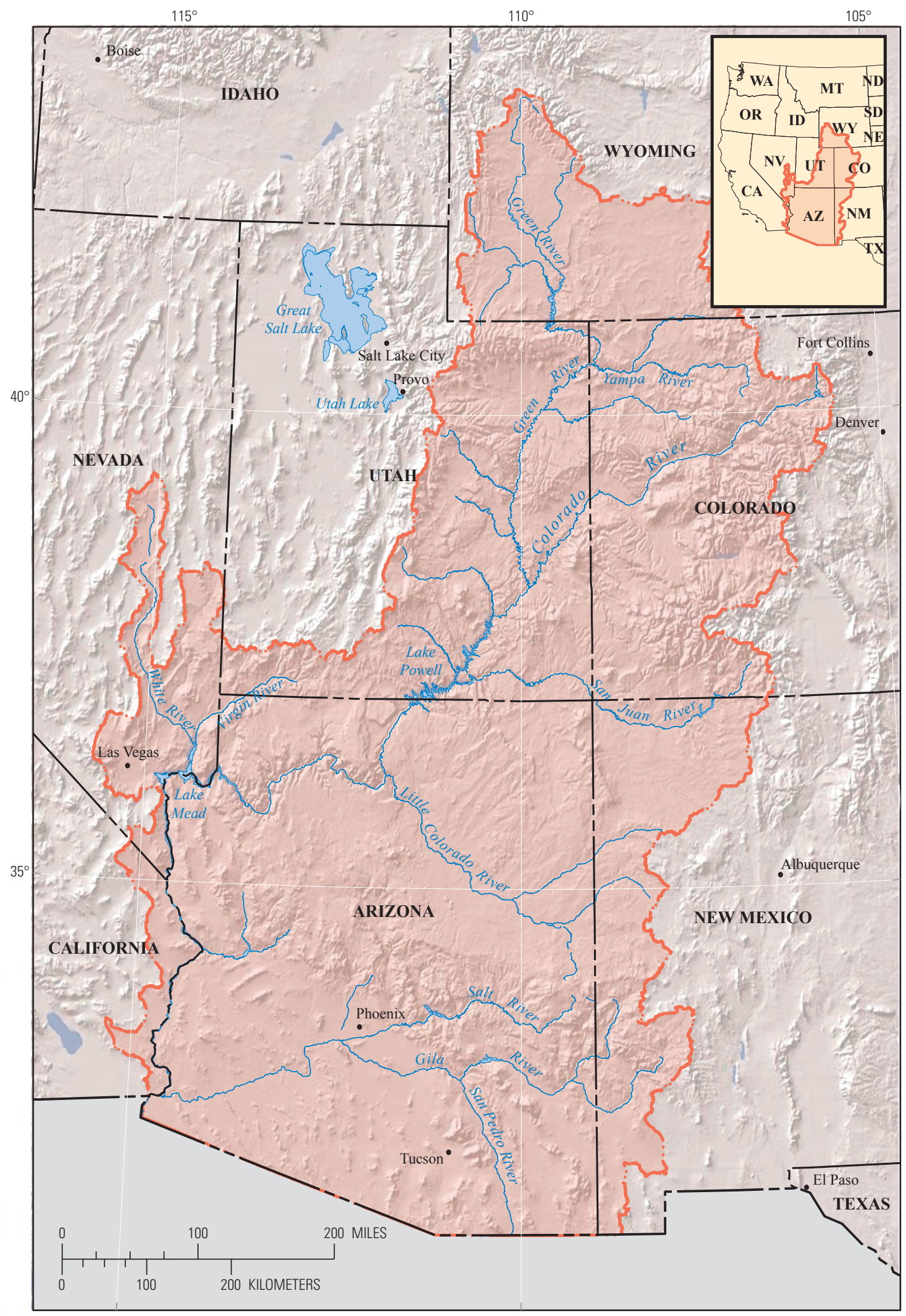

Base modified from U.S. Geological Survey 1:100,000-scale digital data

Figure 4. Location of the Colorado River Basin, within the United States. (From Alley and others, 2013, fig. 4) 
Upper Colorado River Basin. The methods included continuous estimation of groundwater discharge to streams at selected sites for periods of as long as 30 years (Miller and others, 2014; Miller and others, 2015; Rumsey and others, 2015), and the development of a watershed model that predicted groundwater discharge to streams at more than 10,000 stream reaches in the basin (Miller and others, 2016). Results indicate that, on average, more than half the streamflow in the Upper Colorado River Basin is sustained by groundwater discharge to streams, and much of this groundwater discharge to streams originated as precipitation that fell in the past 10 to 100 years (Solder and others, 2016). These results indicate that streamflow depends on groundwater discharge to streams and that the joint groundwater/surface-water resource in the Upper Colorado River Basin may respond rapidly to future anthropogenic and natural changes in the environment.

\section{Snow Pack and Sublimation Component}

Water available for ecological and human needs in the Colorado River Basin is derived largely from high mountain snow (the "snowpack") that accumulates during the winter and spring and melts during the summer each year. These annual mountain snowpacks serve as large natural water reservoirs, and their melting snow provides 70 to 85 percent of the annual surface-water runoff in this region. Determining the amount of water stored in mountain snowpacks each year is important for successfully managing and forecasting water resources in the Colorado River Basin. The USGS utilized two existing models for estimating snowpack water resources as part of the Colorado River Basin FAS - SNODAS (https://data. noaa.gov/dataset/dataset/snow-data-assimilation-systemsnodas-data-products-at-nsidc) and SnowModel (Liston and Elder, 2006). The Colorado River Basin FAS also investigated factors affecting snowpack distribution, such as snowmelt timing and losses of snowpack water by snow sublimation. Peak snowmelt in Colorado is occurring 2 to 3 weeks earlier than in recent history (Clow, 2010), and upward trends in the deposition of windblown dust (a solar heat concentrator) onto mountain snowpacks is contributing to changes in snowmelt timing (Clow and others, 2016). Additionally, physical measurements of snow sublimation (Sexstone and others, 2016), combined with simulated estimates, show that snow sublimation is highly variable and an important component of the water balance in the Colorado River Basin, with losses of as much as 27 percent of winter precipitation (G.A. Sexstone and others, U.S. Geological Survey, written commun., 2017). Results of these Colorado River Basin FAS snowpack water-resources investigations have important implications that can be used for improving water resources forecasting and management in the Colorado River Basin.

\section{Delaware River Basin (2011-15)}

The Delaware River Basin covers 13,500 square miles in parts of four states-New York, New Jersey, Pennsylvania, and Delaware (fig. 5). The population within the basin is approximately 7.3 million.

The basin has the largest interbasin withdrawal of water east of the Mississippi River and provides water to more than 15 million people, half of them outside the basin. Two Supreme Court decrees and coordination by an interstate river basin commission are just part of the history of allocating water resources in the basin. Concerns about the effects of new natural-gas development and the freshwater requirements for endangered sturgeon and a recently discovered mussel species have added new complexities to water management in the upper part of the basin.

With input from more than 60 stakeholder groups, including Federal, state, and local governments, non-governmental organizations, academics, and others, the following issues were identified as priorities in the Delaware River Basin:

- acquisition, management, and integration of improved water-use and water-supply data;

- development of environmental water science that includes enhancement of the existing Decision Support System (DSS) for parts of the Delaware River, definition of relations between streamflow processes and aquatic-assemblage responses in tributaries, and development of a streamflow-estimation tool for ungaged sites (Archfield and others, 2010); and

- development of a hydrologic watershed model to evaluate the effects of water stressors, such as growth of population centers, land-use change, and climate variability and change, on water resources in the basin.

In response to these needs the Water Census developed the following publications and tools. A complete bibliography of the Delaware River Basin FAS is presented in appendix 1.

\section{Improved Water-Use and Water-Supply Information}

Water-use information for 2010 from the four basin states was compiled and quality assured, and consistent water-use estimates were provided for surface-water diversions and withdrawals, groundwater withdrawals, and surface-water return flows. In addition, estimates of unreported domestic use were developed. A report on water use in the basin was published (Hutson and others, 2015), and data on thermoelectric, public-supply, agricultural, commercial, and other uses 


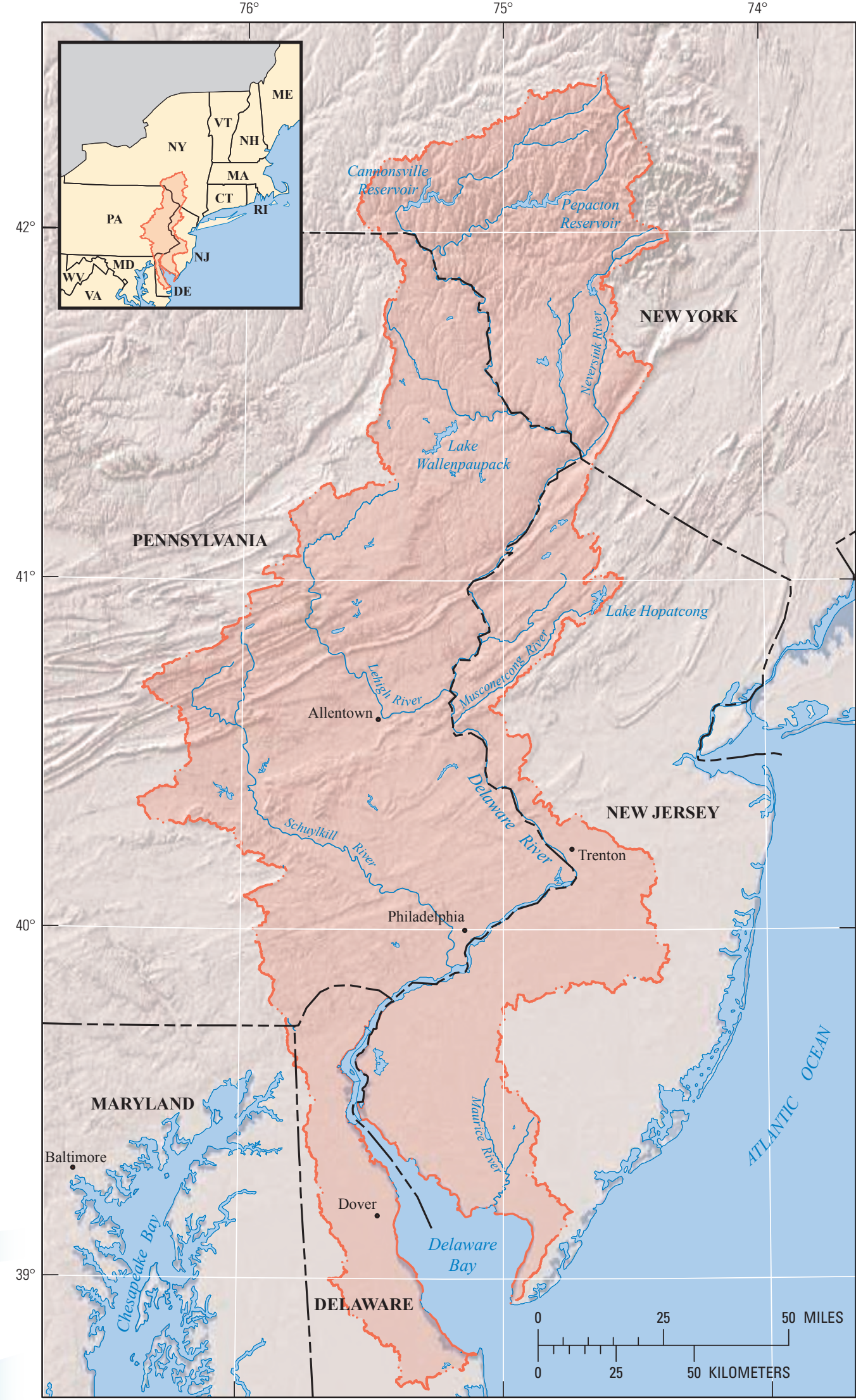

Base modified from U.S. Geological Survey 1:100,000-scale digital data
Figure 5. Location of the Delaware River Basin. (From Alley and others, 2013, fig. 6) 
are reported for 427 12-digit hydrologic unit code (HUC-12) subbasins. This was the first time USGS studies provided yearly water-use estimates at the detailed HUC-12 scale (a goal of the Water Census). Data for the HUC-12 subbasins are available (Hutson and others, 2016a) as Excel ${ }^{\circledR}$ tables at the Water Census ScienceBase-Catalog (https://www.sciencebase. gov/catalog/item/5762a410e4b07657d19a71cb).

\section{Basin Hydrologic Model}

The Water Availability Tool for Environmental Resources (WATER) is a hydrologic watershed model developed by the Water Census for the non-tidal Delaware River Basin (see Box B). The model includes information on water use, and projections of future land use and climate change for the years 2030 and 2060. The model and developed datasets have been published and are publicly available (Williamson and others, 2015; Williamson and Lant, 2015). Model scenarios describing possible future effects of climate and land-use change on basin water resources are also contained in these publications. The model is currently being used in a detailed assessment of how changes in climate might affect management of future reservoir releases.

\section{Environmental Water Science on Mainstem}

Flow on the mainstem of the Delaware River is controlled, to a large extent, by waters released from drinkingwater reservoirs and power-supply reservoirs. Releases are regulated to meet a variety of needs, including water-supply demands, protection of downstream fisheries habitat, and repelling the upstream movement of saltwater in the Delaware Estuary. These releases need to be managed to protect the cold-water fisheries on the Delaware River and maintain aquatic community diversity, structure, and function. The Delaware FAS developed a tool to evaluate the relation among flows, environmental variables (such as temperature), and ecological response. The Water Census study on the mainstem of the Delaware River determined the environmental water needs of a variety of freshwater species such as fishes, mussels, and submerged aquatic vegetation in the Upper Delaware River Basin. This information was incorporated into a DSS that allows managers to evaluate how different flow scenarios might affect the amount of habitat that is available for each species to spawn, grow, and reproduce (Maloney and others, 2015). The DSS tool has been published and is being used to assist the Flexible Flow Management Committee of the Delaware River Basin Commission in evaluating how releases could affect fish communities on the Delaware River (Talbert and others, 2014).

\section{Environmental Water Science on Tributaries}

Environmental data are typically collected on tributaries where no flow information is available. To assist ecologists in the Delaware River Basin interested in studying relations between major components of streamflow (magnitude, durations, frequency, timing, and rate of change) and the response of aquatic assemblages (environmental waters), Delaware River Basin Streamflow Estimator Tool (DRB-SET) was developed (Stuckey, 2016). This tool can be used to assist managers in making decisions about meeting human water needs while maintaining healthy ecological communities in streams. A user's manual developed for the DRB-SET has been published and the tool is available to the public (Stuckey and Ulrich, 2016).

\section{Coastal Carolinas Basins (2015-19)}

The coastal regions of the United States are substantially more crowded than the United States as a whole, and although these growing coastal areas represent a nexus of natural resources and economic opportunity, they also represent areas of increasing conflict over these resources. Although other areas of the United States are also growing, the land limitations in coastal regions often lead to higher population densities and a sharper, more focused interface between fresh- and saltwater ecosystems. Population growth has tripled since the 1970s in the Coastal Plain portions of the Lower Cape Fear River and Lower Yadkin/Pee Dee/Waccamaw River Basins in North Carolina and South Carolina, a region bounded by the Atlantic Ocean, Atlantic Intracoastal Waterways, and tidally affected brackish rivers (fig. 6). Coastal areas of the southeastern United States, particularly in the Carolinas, are experiencing increased annual pulses of tourist populations that often place unanticipated stresses on the natural resources. This confluence of people and a geography that is highly susceptible to the effects of hurricanes, routine droughts, and climate change/sea-level rise has presented unique challenges to water-resource managers and environmental regulators. To further highlight and confirm the water conflict in this region of the Carolinas, in 2015 (just prior to the beginning of the Coastal Carolinas FAS), the North Carolina General Assembly passed a bill (NC House Bill 186, March 10, 2015, http:// www.ncleg.net/Sessions/2015/Bills/House/PDF/H186v6. pdf) calling for " ....an evaluation of the adequacy of currently available supplies to meet the expected long-term needs for all water demands... of the portions of the Cape Fear River Basin within Brunswick, New Hanover, and Pender Counties ...".

The Coastal Carolina Basins FAS (fig. 7) has four major components: (1) refined water-use data and estimates of HUC-8 water use; (2) a groundwater-flow and saltwaterintrusion model of the surficial, Castle Hayne, Crouch Branch/ Peedee, and McQueen Branch/Black Creek aquifers for the study area; (3) surface-water models of the Cape Fear River and Yadkin/Pee Dee/Waccamaw River Basins to simulate watershed/streamflow response to various future scenarios of climate and land-use changes and water use; and (4) ecological response models relating fish and macroinvertebrates to streamflow and land use in the Cape Fear River and Yadkin/ PeeDee/Waccamaw River Basins. Additionally, existing population change forecasts from the U.S. Census Bureau (U.S. 


\section{Box B. Applying the Science to Water Management in the Delaware River Basin}

The Delaware River Basin Commission (DRBC) is a federal-state compact agency established in 1961 and charged with conservation, utilization, development, management, planning, control, protection, and preservation of the waters of the Delaware River Basin and Estuary. The DRBC works collaboratively with the basin states (Delaware, New Jersey, New York, and Pennsylvania) on all aspects of integrated water resource management including water allocation and the protection of drinking water and other water intakes.

In the 1960s, after eight consecutive years of below normal precipitation and a severe drought, the DRBC worked with the states and stakeholder to develop flow and drought management plans and actions that would ensure that the basin would be resilient to a similar drought of record. While the states are responsible for many aspects of the plans related to water conservation, the DRBC has the overall responsibility to preserve regional storage for the purposes of water supply, flow augmentation, and water quality in the Delaware River, and salinity control in the Delaware River Estuary. These plans were adopted in 1983 and have been modified over time to address different stakeholder issues, including minimum releases for ecological protection and some limited spill mitigation, without impacting other reservoir purposes such as water supply.

With the predicted trends in precipitation and temperature during this century, the DRBC has embarked on a project to assess the potential risks to DRBC's overall flow and drought management goals. Then, plans and programs will be developed to adapt to identified risks. To do this, DRBC will use the Water Availability Tool for Environmental Resources (WATER), developed during the Water Census pilot project for the Delaware River Basin and the DRBC's Water Management Planning Support Tool (DRB-PST). Used together, the DRBC will be able to assess future water availability and drought resilience to educate decision makers about risks to the basin and begin the process of adaptive management planning and implementation.

With WATER, it is possible to generate the inflows and associated water use information, which are the major factors that determine water availability with DRB-PST. Precipitation, temperature, soil characteristics, land use, slopes, and other relevant information are used by WATER to develop a water budget for sub-basins and calculate the amount of runoff (streamflow) expected to reach the various streams and reservoirs in the basin. The streamflows are used by DRB-PST to simulate the flow and drought management programs and assess how well they perform under the future conditions.

Preliminary results indicate that the changes to streamflows, which enter reservoirs, streams, and rivers, are primarily seasonal and increase by a modest amount in the future. However, the seasonality of the streamflow shifts and is primarily related to changes in the snow pack and evaporation. The change in snow pack is primarily related to the change in temperature and not the lack of precipitation. The precipitation falls as rain rather than snow and arrives at the reservoir as runoff within days rather than snow melt weeks or months later. As a result, the timing of reservoir refills is likely to change rather than the overall amount of water that reaches the reservoirs. Streamflows in the summer are reduced, but indications are that those reductions are primarily due to the increased evapotranspiration resulting from increased temperatures.

The DRBC also uses hydrodynamic and water quality models to evaluate salinity and chloride concentrations in the Delaware Estuary. Salinity and chlorides are problematic for drinking water and other water intakes due to the potential for increased corrosion and the complexity of treatment technologies. Model results indicate that the Sea Level Rise (SLR) in the Delaware Estuary may hinder the ability of the existing flow management programs to control salinity. DRBC will be using a linked combination of WATER, DRB-PST, and these other models to evaluate how freshwater inflows into the estuary will alter the salt water-fresh water interface.

Once the risks of increased precipitation, temperature, and sea level rise have been evaluated, DRBC can determine if existing flow management programs can meet stakeholder needs and also maintain the current level of salinity control. If additional storage or other infrastructure is needed, combinations of flow management and infrastructure programs can be developed, constructed, and/or implemented to address the impacts of predicted trends in climate and SLR 
Census Bureau, 2012) and spatial urban-growth scenarios based on research from North Carolina State University and the USGS are being applied to the study area to drive various land-use and water-use change scenarios that will be simulated with the groundwater, surface-water, and ecological-response models. Stakeholder input was important in establishing these major study components.

The water-use component includes developing a sitespecific database of water use for the study area, refining county-level estimates and aggregating site-specific wateruse data to the HUC-8 level, exploring improved methods to estimate agricultural withdrawals, and compiling available water-use projections. The study is focusing on water-use data for the period 1995-2015.

An updated and refined groundwater-flow model of the study area will be used to inform resource decisions based on various current and future climate, land-use, and groundwateruse scenarios. The groundwater-flow model will be converted

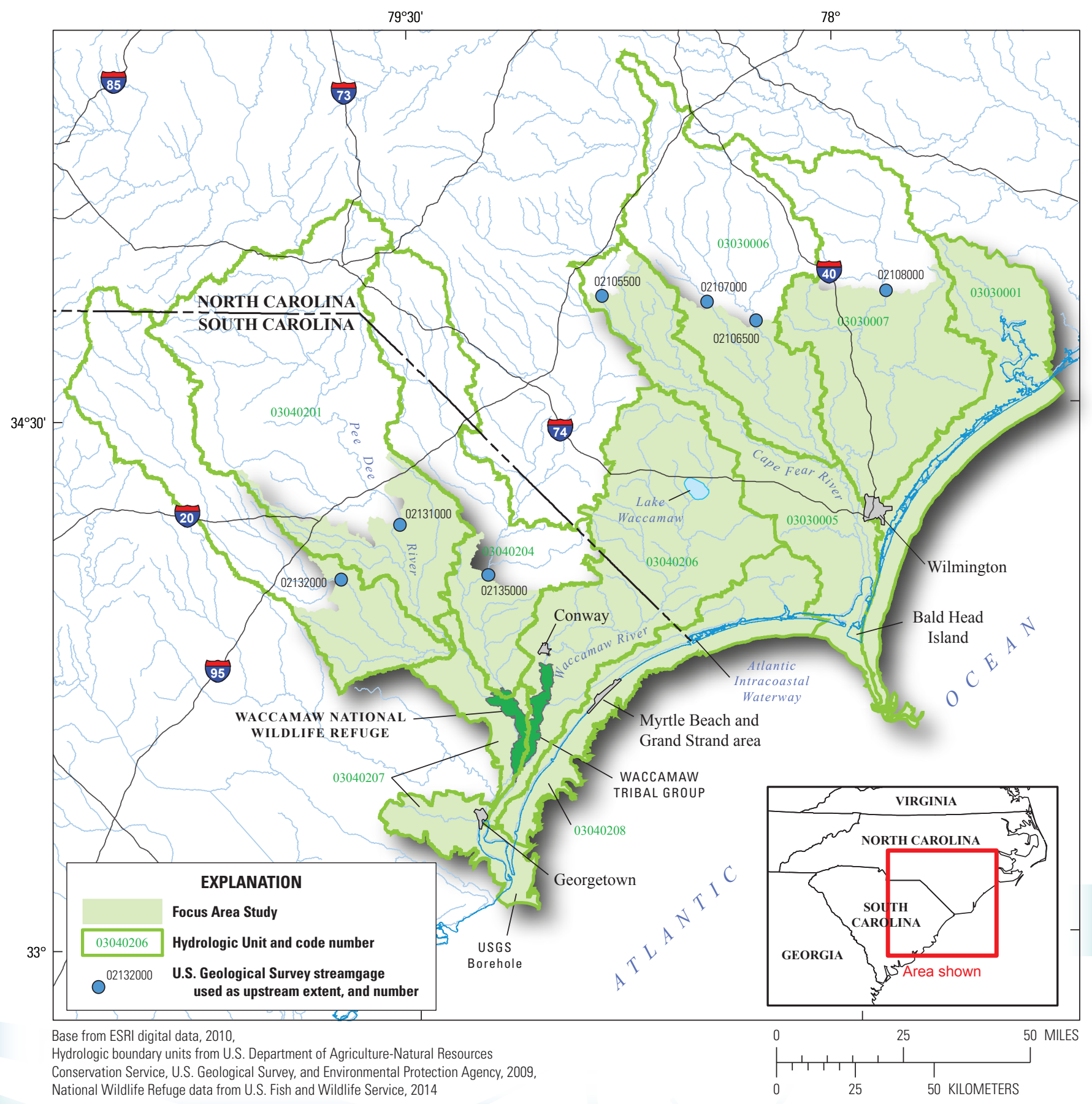

Figure 6. Location of the Coastal Carolina Basins Focus Area Study. 


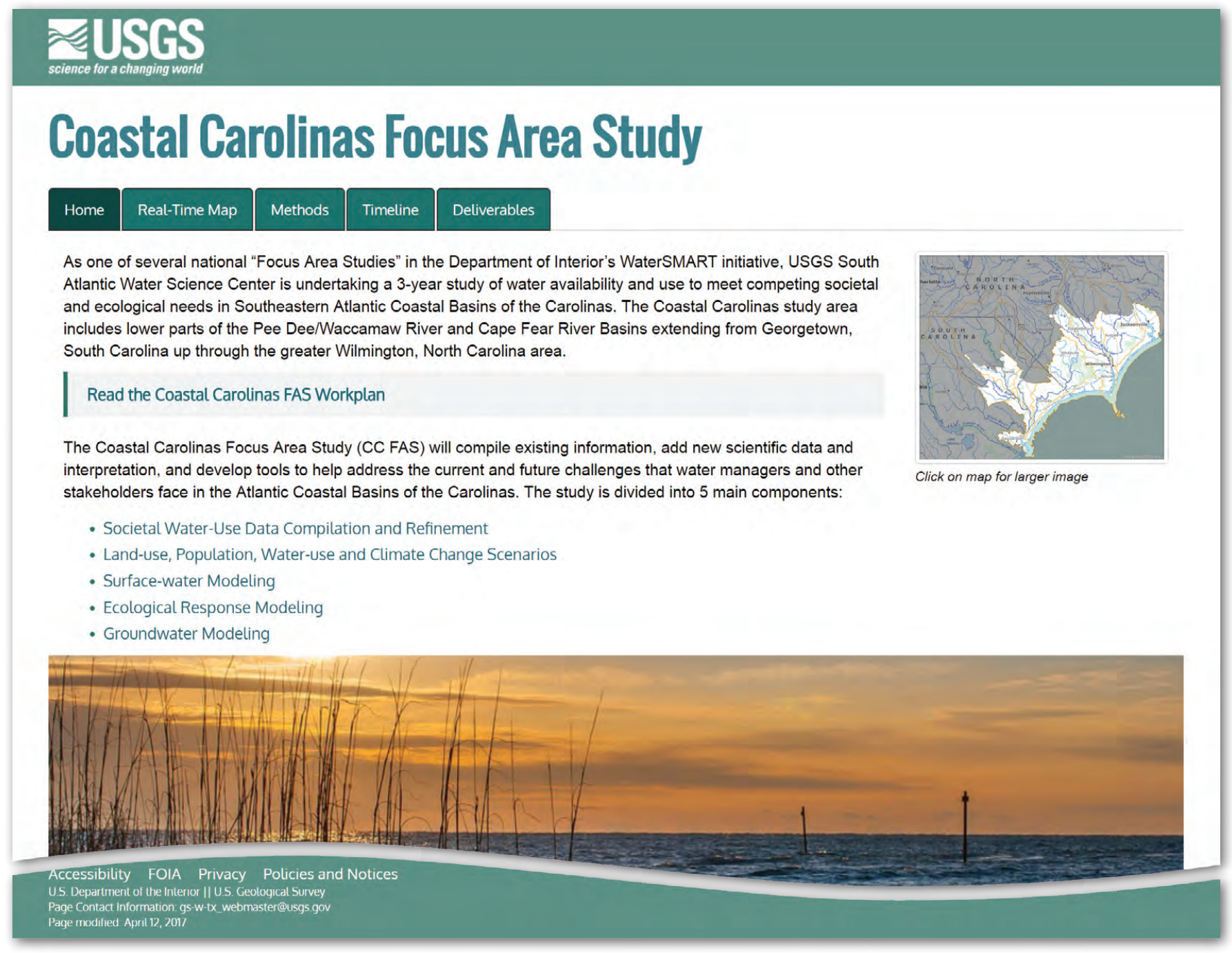

Figure 7. U.S. Geological Survey Coastal Carolina Basins Focus Area Study webpage. (From U.S. Geological Survey, 2017a)

to a model that can be used to evaluate potential saltwater intrusion into the aquifers resulting from groundwater pumping scenarios for as many as two localized population centers within the study area.

Surface-water models built using the Soil and Water Assessment Tool (SWAT) model (Arnold and Fohrer, 2005) will be used to simulate streamflows at ungaged ecological sampling sites and key locations for water-supply in the study area, while also accounting for water-use and climate-change scenarios. The simulated streamflow data from the Yadkin/ Pee Dee/Waccamaw River surface-water model will be incorporated into the existing Pee Dee River and Intracoastal Waterway Salinity Intrusion Model-Decision Support System (PRISM-2 DSS) (Conrads and others, 2013), which was developed to evaluate the salinity dynamics of the Atlantic Intracoastal Waterway and the Waccamaw River on the basis of variability of streamflow resulting from climate change and the effects of sea-level rise. The PRISM-2 DSS, with updated streamflow information, will be used to simulate the effects of future climate, land-use, and water-use changes on the frequency, magnitude, and duration of saltwater intrusion.

Empirical models relating fish and macroinvertebrate metrics to flow metrics and land use will be developed for the Yadkin/Pee Dee/Waccamaw and Cape Fear River Basins by using daily streamflows obtained from the surface-water models. These models will also be used to predict aquaticbiota community changes associated with the various wateruse, land-use (urbanization), and climate-change scenarios. The ecological-flow response models will also be used to test the efficacy of various alternatives for flow objectives for the protection of ecological integrity in streams by adding these actual or hypothetical ecological-flow objectives into current and projected flow and water-use scenarios.

Combined, these new data and tools can be used by resource managers to plan future surface-water allocations and groundwater development and withdrawals as stakeholders evaluate potential consequences on ecology and susceptibility of the aquifers to saltwater contamination. 


\section{Red River Basin (2015-19)}

The Red River Basin is an area of about 93,200 square miles with a population of about 4.3 million people. The basin is characterized by flat agricultural land and is relatively arid, with annual precipitation ranging from less than 30 inches in the western headwaters to 50 inches at the confluence with the Mississippi River (fig. 8). Concerns and conflicts about water in the Red River Basin have been growing because of increasing needs for freshwater in the rapidly expanding Dallas-Ft. Worth, Texas, area; cycles of severe drought in the basin; and increases in water use for power generation and other purposes. The Red River Compact, authorized by Congress in 1955 and signed by the States of Arkansas, Louisiana, Oklahoma, and Texas in 1978 (P.L. 92-500, 33 USG, 33 U.S.C., sections 1251 et seq.), documents the volume of water each state in the basin can use or store from the Red River Basin. Despite the compact, litigation over water use among member states recently occurred: Tarrant Regional Water District v. Herrmann-U.S. Supreme Court, 2012 (https://www. supremecourt.gov/opinions/12pdf/11-889_5ie6.pdf); State of Oklahoma, Choctaw Nation, Chickasaw Nation, Oklahoma City Settlement, 2016 (https://www.waterunityok.com/).

The USGS worked collaboratively with Federal, State, and local governments, Tribes, regional water managers, and other stakeholders to develop an approach to comprehensively assess water budgets and water availability under current hydrologic, land-use, and water-demand conditions and for a range of future conditions. To achieve the aforementioned comprehensive assessment, the Red River FAS is divided into four objectives: (1) refinement and enhancement of water withdrawal estimates (1980-2015) to provide a detailed picture of water use in the basin, (2) development of a groundwater-flow model to quantify groundwater/surface-water interactions and likely effects of increased withdrawals upstream from the Denison Dam on Lake Texoma, (3) construction of a rainfall-runoff model to simulate streamflow and compute daily water balances for each hydrologic response unit within the basin, and (4) develop an understanding of the relation between changes in water availability and the fish-community response for the basin within Oklahoma and Texas. Products of this study will include a water-use database, complementary groundwater and surface-water models, and an assessment of environmental water needs for the Red River Basin (fig. 9).

\section{Upper Rio Grande Basin (2015-19)}

The growing gap between water supply and demand in the Upper Rio Grande Basin has resulted in ongoing conflict and litigation among Federal, Tribal, State, and local users. The USGS Upper Rio Grande FAS is assessing existing knowledge and contributing new scientific data and interpretation to help stakeholders address these critical water issues.

The Upper Rio Grande River drains 32,000 square miles and flows 670 miles from its headwaters in Colorado (peak elevation $14,351 \mathrm{feet}[\mathrm{ft}]$ ) to an area sixty miles downstream from El Paso, Texas (elevation 3,450 ft) (fig. 10). The Upper
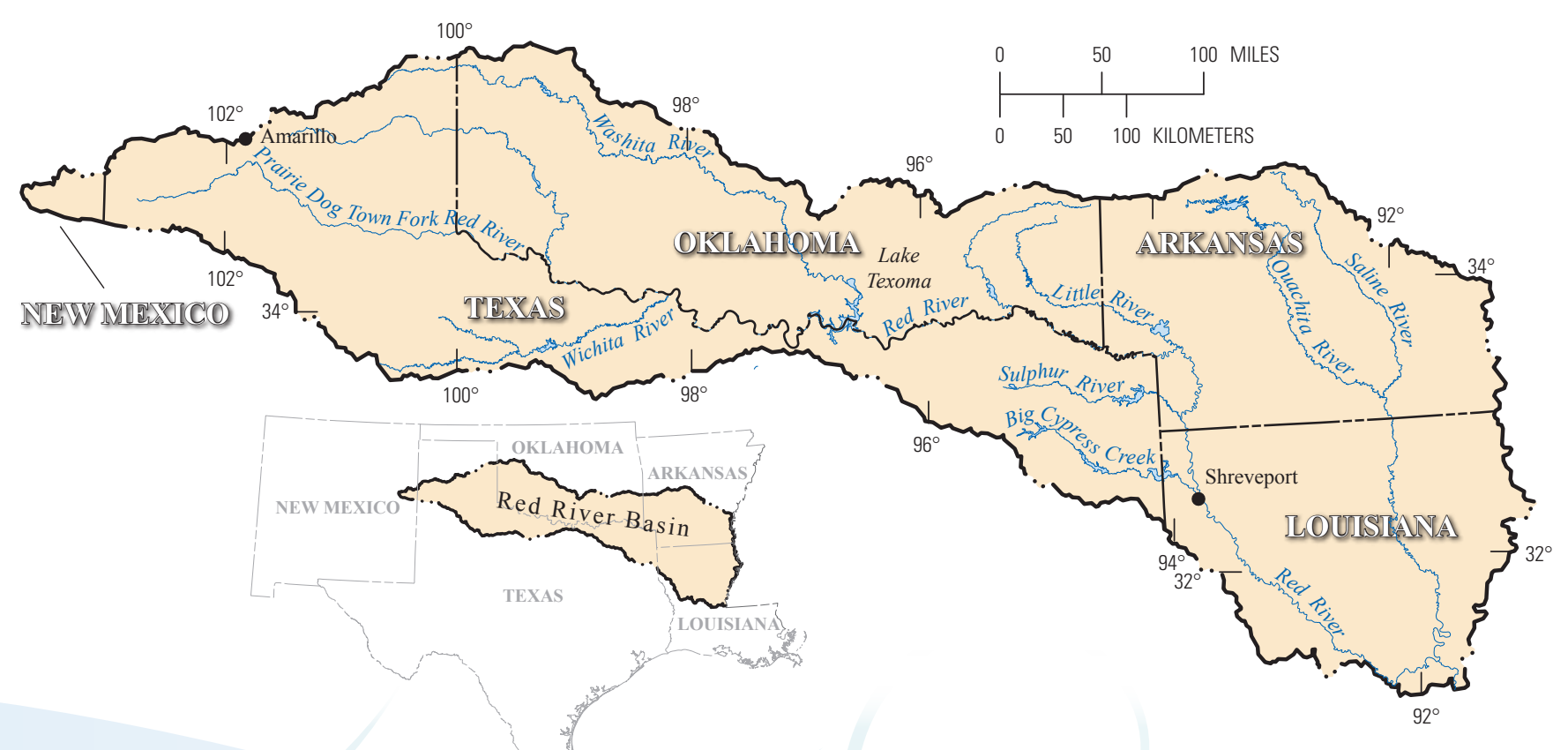

Base from U.S. Geological Survey 1:1,000,000-scale digital data, 2014

Figure 8. Location of the Red River Basin. 


\section{ZUSGS \\ Red River Focus Area Study

\begin{tabular}{|c|c|c|c|c|c|c|}
\hline Home & Real-Time Map & Methods & Timeline & Deliverables & Staff & Presentations \\
\hline
\end{tabular}

The USGS is undertaking a 3-year study of water use, availability, and change in the Red River basin in one of several national "Focus Area Studies" in the Department of Interior's WaterSMART initiative. The Red River basin covers more than 93,000 square miles in New Mexico, Texas, Oklahoma, Arkansas, and Louisiana with a population of about 4.3 million people. Water resources in the basin are being stressed by increasing water demands and increasingly severe droughts. A comprehensive water-resource assessment of the basin is needed to enable sustainable water use.

The Red River Focus Area Study (FAS) will compile existing information and add new scientific data and interpretation to facilitate better management of water resources for use by humans and maintenance of water quality and ecological flows in the basin. The study is organized around four important components that are intended to improve the quality and accessibility of information on water availability for humans and ecosystems in the Red River basin, and to advance technical water assessment capabilities:

- Water Use

- Groundwater Flow Model

- Rainfall-Runoff (Surface Water) Model

- Ecological Flows

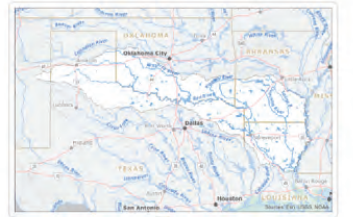

Click on map for larger image

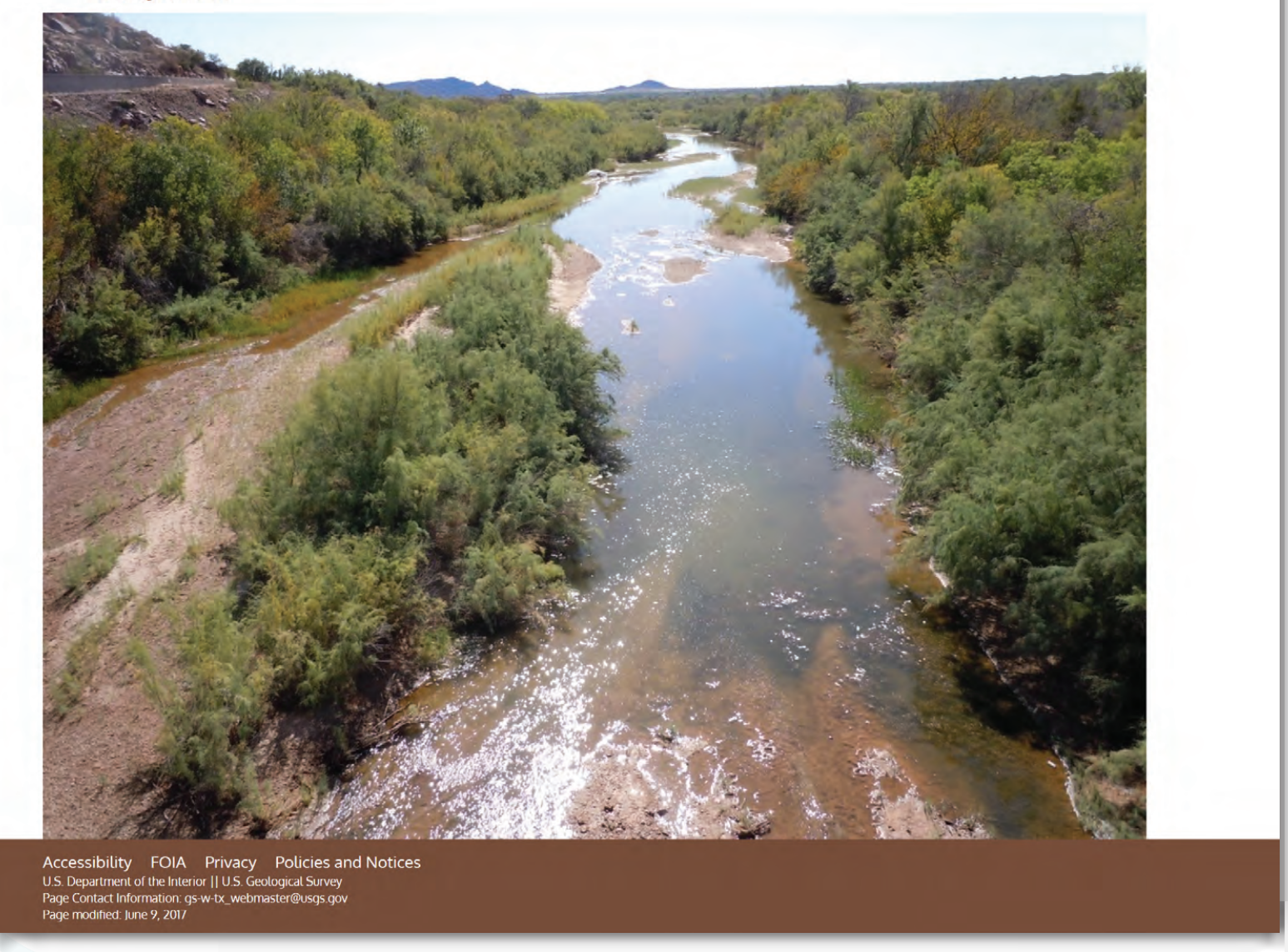

Figure 9. U.S. Geological Survey Red River Basin Focus Area Study webpage. (From U.S. Geological Survey, 2017b) 


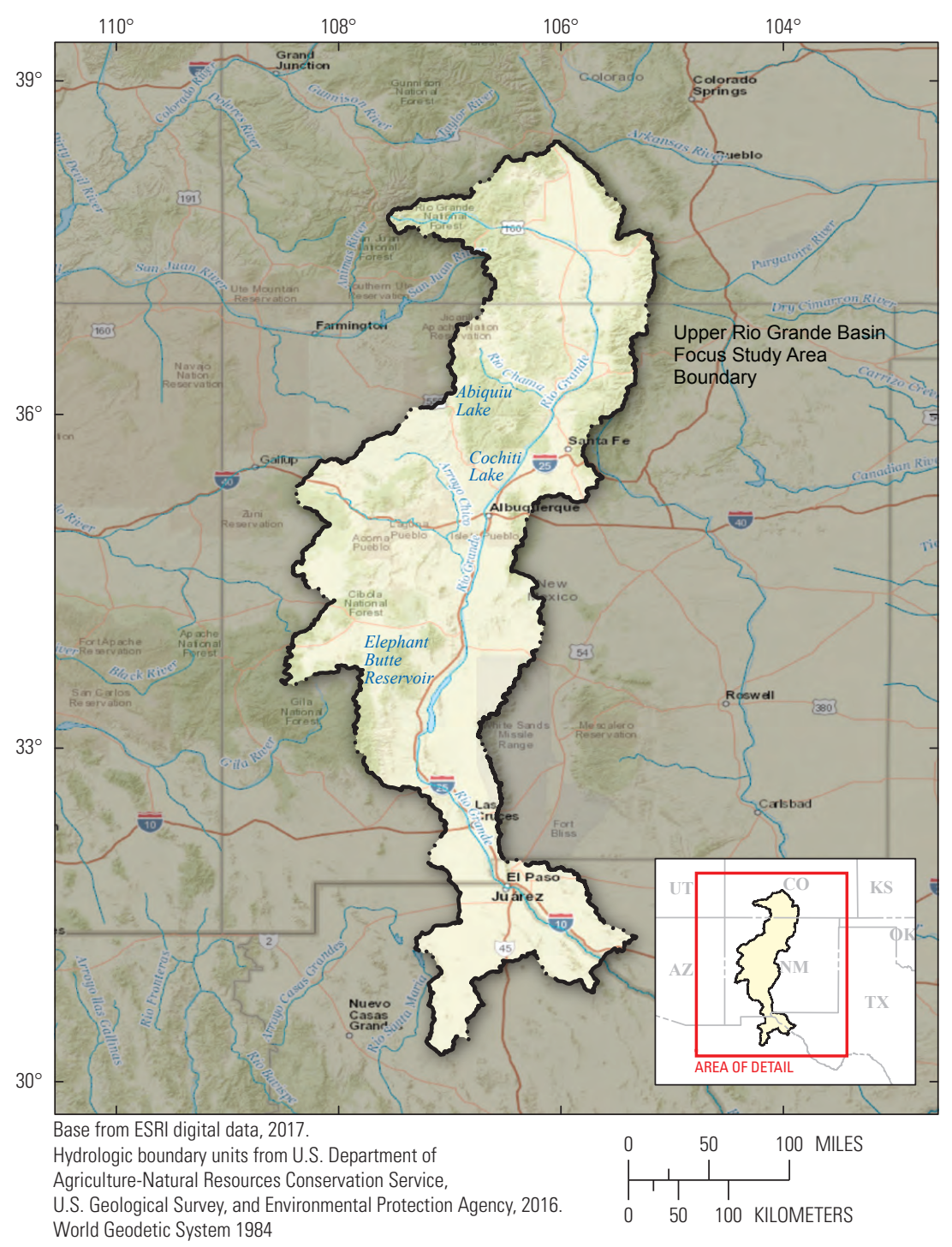

Figure 10. Location of the Upper Rio Grande River Basin.

Rio Grande Basin is an arid to semi-arid region where disputes over water shortages have occurred for more than 100 years. Basin features vary from alpine and forested mountains and river gorges in the Southern Rocky Mountains, to riparian forests (bosque) and the broad valleys and high desert of central New Mexico, to the Chihuahuan Desert along the boundary between Texas and Mexico.

The conjunctive use of water in the Upper Rio Grande Basin takes place under a myriad of legal constraints, including the Upper Rio Grande Compact between the States, an international treaty with Mexico, and several Federal water projects. The conveyance and use of surface water in the Upper Rio Grande River Basin is achieved through an engineered system of reservoirs, diversions, and irrigation canals. The region is experiencing a decrease in water supply and a trend toward less and earlier snowmelt due to extended drought and climate change. These conditions have led to diminishing snowmelt and groundwater recharge. At the same time, changes in climate and an extended period of drought have reduced reservoir water supplies, leading to increased use of groundwater for irrigation, municipal, and industrial uses. A decrease in water supply at a time of increasing demand from population growth and shifting agricultural cropping patterns means that current groundwater withdrawals exceed recharge rates. The growing gap between water supply and demand has resulted in continued conflict and litigation among Federal, Tribal, State, and local users. Quantification of key water-budget components as part of this study will support many regional efforts to understand and sustainably manage finite water resources in the Upper Rio Grande River Basin, including updates to the New Mexico State Water Plan (http://www.ose.state.nm.us/Planning/state_plan.php), the Rio Grande Transboundary Integrated Hydrologic Model (https://nm.water.usgs.gov/projects/program.areas/files/R-G. transboundary.integrated.model.PNG), the Upper Rio Grande Water Operations Model (http://www.spa.usace.army.mil/ 
Missions/Civil-Works/URGWOM/), and the Rio Grande Basin of the USGS National Hydrologic Model (https://wwwbrr. cr.usgs.gov/projects/SW_MoWS/index.html).

The Upper Rio Grande FAS is compiling and interpreting the spatial distributions and temporal trends of key wateravailability and -use components to help stakeholders address water issues. Compilation of water-use data by sector (such as public supply, irrigation, and domestic) from 1985 to 2015 for the 22 HUC- 8 subbasins will inform local, regional, and State water planning. Water losses from actual crop and landscape evapotranspiration are being quantified with a USGS remote-sensing-based model with Landsat satellite images, and verified with measured evapotranspiration data. Groundwater status and trends throughout the basin are being assessed through development of a basin-scale hydrogeologic framework, water-level surface and change maps, and geostatistical trend analysis. Improved snow-process modeling will provide more accurate estimates of snow accumulation, sublimation losses, and snowmelt rate and timing. Streamflow trend analyses and new base-flow separation methods are quantifying the connection between groundwater and surface water throughout the basin. Data and results from each component will be integrated in a regional calibration of the USGS national-scale watershed model, built on the precipitation runoff modeling system (PRMS) (Regan and others, 2018), which will provide a new tool to synthesize and visualize historical, current, and future water availability and use across the basin.

The spatially distributed water-budget products of each component of this study will be compiled within a nationalscale database and integrated to improve understanding of interactions occurring within the basin. Summarized results will be publicly displayed on interactive maps at the "RealTime Map" tab on the project webpage, depicted in figure 11 below (https://webapps.usgs.gov/watercensus/riogrande_fas/).

\section{ZUSGS}

Upper Rio Grande Basin Focus Area Study

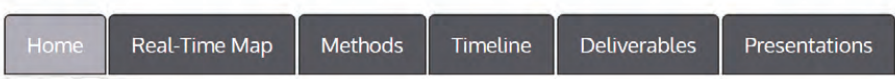

USGS is undertaking a 3-year study of water use, availability, and change in the Upper Rio Grande Basin in one of several national "Focus Area Studies" in the Department of Interior's WaterSMART initiative. The Upper Rio Grande study area runs 670 miles from its headwaters in Colorado through New Mexico and northern Mexico to Ft. Quitman, Texas. Along its river corridor, it is a primary source of irrigation water for food, fiber and feed production and is used as a source for municipal supply by the cities of Albuquerque, Las Cruces, El Paso and Ciudad Juarez.

Read the Upper Rio Grande Workplan

The Upper Rio Grande Basin Focus Area Study (URGB FAS) will compile existing information and add new scientific data and interpretation to help stakeholders face current and future water issues. The study is organized around the important components affecting water availability in the Basin:

$$
\begin{aligned}
& \text { - Water Use } \\
& \text { - Groundwater } \\
& \text { - Evapotranspiration }
\end{aligned}
$$

$$
\begin{aligned}
& \text { - Snow Processes } \\
& \text { - Streamflow Processes } \\
& \text { - Watershed Processes }
\end{aligned}
$$

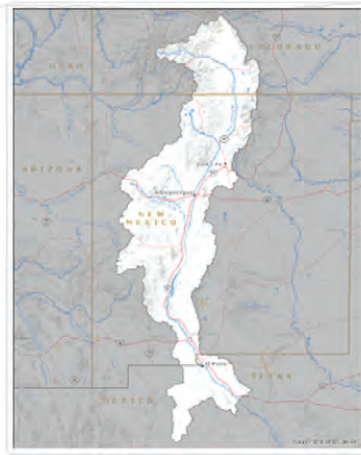

Click on map for larger image

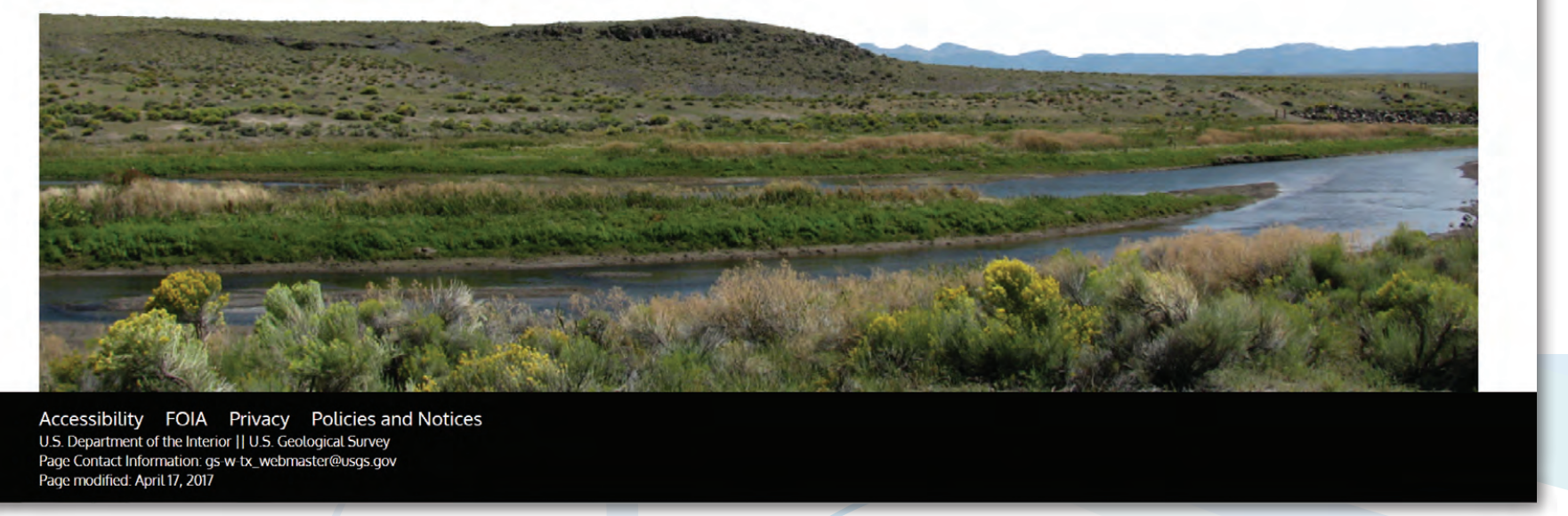

Figure 11. U.S. Geological Survey Upper Rio Grande River Basin Focus Area Study webpage. (From U.S. Geological Survey, 2017c) 


\section{Topical Studies}

Six topical studies key to the Water Census are discussed below. As described earlier, some topical studies, such as surface water, groundwater, evapotranspiration, and water use, provide uniform information about specific water-budget components for a consistent national framework of information vital to the understanding of water availability. Other topical studies provide research and innovative tools for environmental water science and drought science. For each topical study, this report explains the information needs and past and ongoing Water Census efforts to fill them.

\section{Surface Water}

The SECURE Water Act calls for annual updates of river-basin flows and analysis of historical trends. The USGS Groundwater and Streamflow Information Program provides a strong and essential foundation for this type of streamflow information. The USGS operates more than 8,000 streamgages to provide information on floods, droughts, and current water availability across the United States. This network of streamgages provides real-time information and historical context for water-resources planning and assessment. For studies of trends in streamflow and water availability, long historical records are critical.

\section{Flow at Ungaged Locations}

Because the streamgage network cannot provide direct observations of streamflow at every location of interest, information about streamflow at ungaged locations is needed. To meet this need, the USGS has long published information through its WaterWatch (https://waterwatch.usgs.gov) and StreamStats (https://water.usgs.gov/osw/streamstats/) web tools, which provide estimates of streamflow and streamflow statistics using well-established methods. The Water Census seeks to improve upon the information that is currently available for ungaged locations by providing estimated time series of daily streamflow for subwatersheds nationally. Initial exploratory work was conducted to assess the feasibility of using different statistical models for this type of work (Farmer and others, 2014, 2015). On the basis of these results, the most promising methods have been refined and used to develop models for the entire conterminous United States. These statistical models will be applied to ungaged locations throughout the Nation and the results will be publicly available in 2018 .

In addition to the statistical models, a daily deterministic precipitation-runoff model has been developed for the conterminous United States. This USGS model simulates the processes that generate runoff on the landscape (see fig. 12) and routes the resulting flow through the river system. Because it simulates hydrologic processes with physically based code, this model can be used not only to simulate

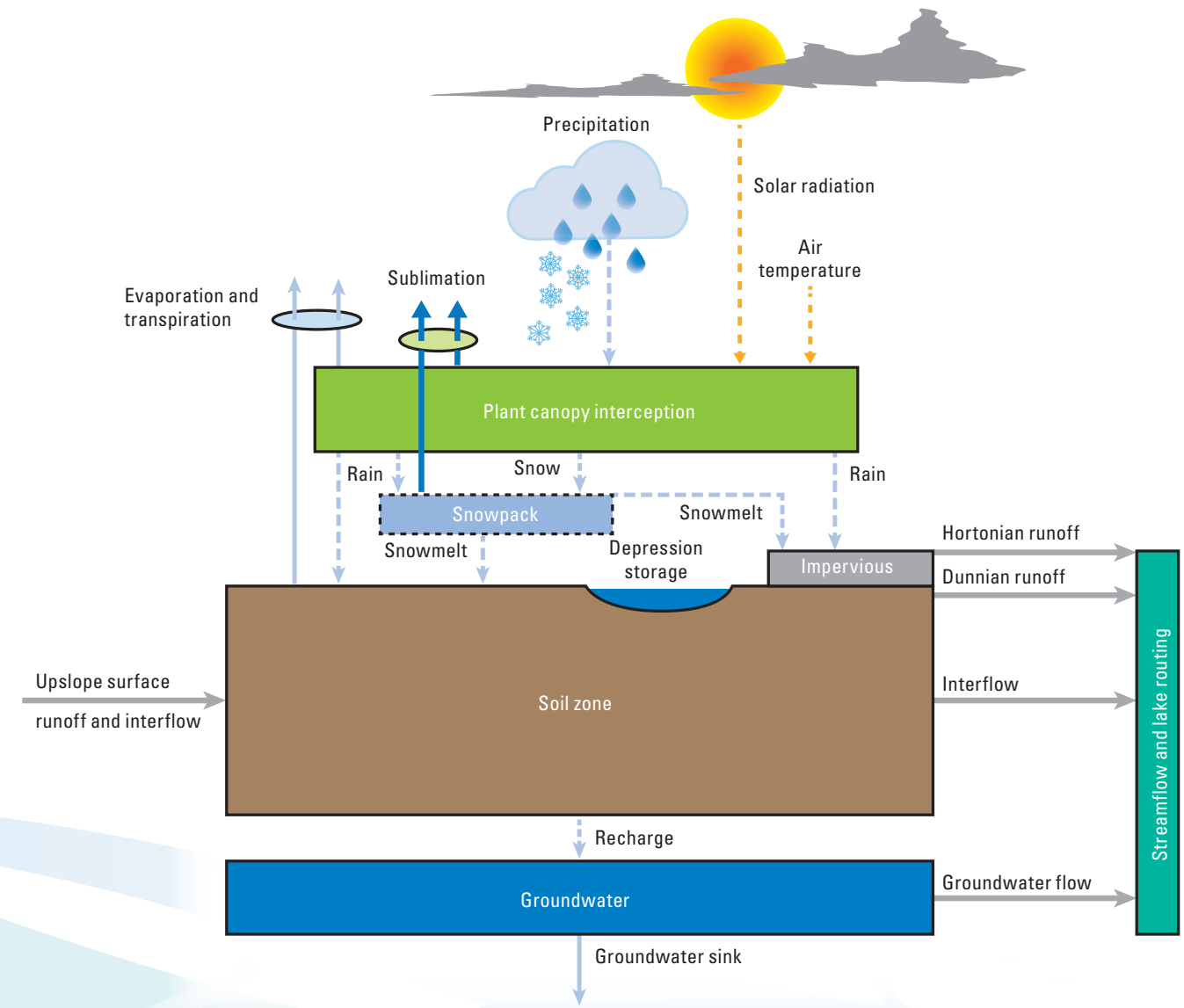

Figure 12. U.S. Geological Survey Precipitation Runoff Modeling System (Modified from Regan and others, 2018) 
historical streamflow time series, but also to gain insight into all components of the water budget (such as soil-moisture storage or snowmelt in specific parts of the country). The model can also be used to explore "what-if" scenarios; for example, what if land use changes - how does that affect hydrologic processes and water availability? What if climate changeshow will water supply be affected? A complete description of the USGS NHM is given by Regan and others (2017). For daily simulation, the USGS NHM-PRMS was built using the USGS Precipitation Runoff Modeling System (Markstrom and others, 2015) and a geospatial fabric that ties the model to the river network and observational data (Viger, 2014; Viger and Bock, 2014). Recent improvements to the USGS NHM-PRMS include improved parameterization of snowmelt, depression storage, and groundwater discharge. Improved methods for regional calibration of the model have also been developed to allow application at ungaged locations (Bock and others, 2016; Markstrom and others, 2016).
Figure 13 shows results for June 1, 2010, from the USGS NHM-PRMS built using PRMS version 5 and the default parameters published by Driscoll and others (2017). The river reaches are colored on the basis of whether flows were low, normal, or high for that time of year. For example, in the USGS NHM-PRMS simulation, the orange river reaches along the west coast are flowing at less than the 10th percentile for this date, whereas the blue reaches in the central United States are flowing at greater than the 90th percentile for this date. Additional results from the USGS NHM-PRMS will be available for download in FY 2018.

Although most existing work is focused on the conterminous United States as a result of limitations in the available data for other states and territories, some work is also proceeding in Alaska and Hawaii. For example, an extension to PRMS to simulate glacial runoff was developed to enhance the model's suitability for simulating runoff and streamflow in Alaska (Van Beusekom and Viger, 2016). In addition, ongoing

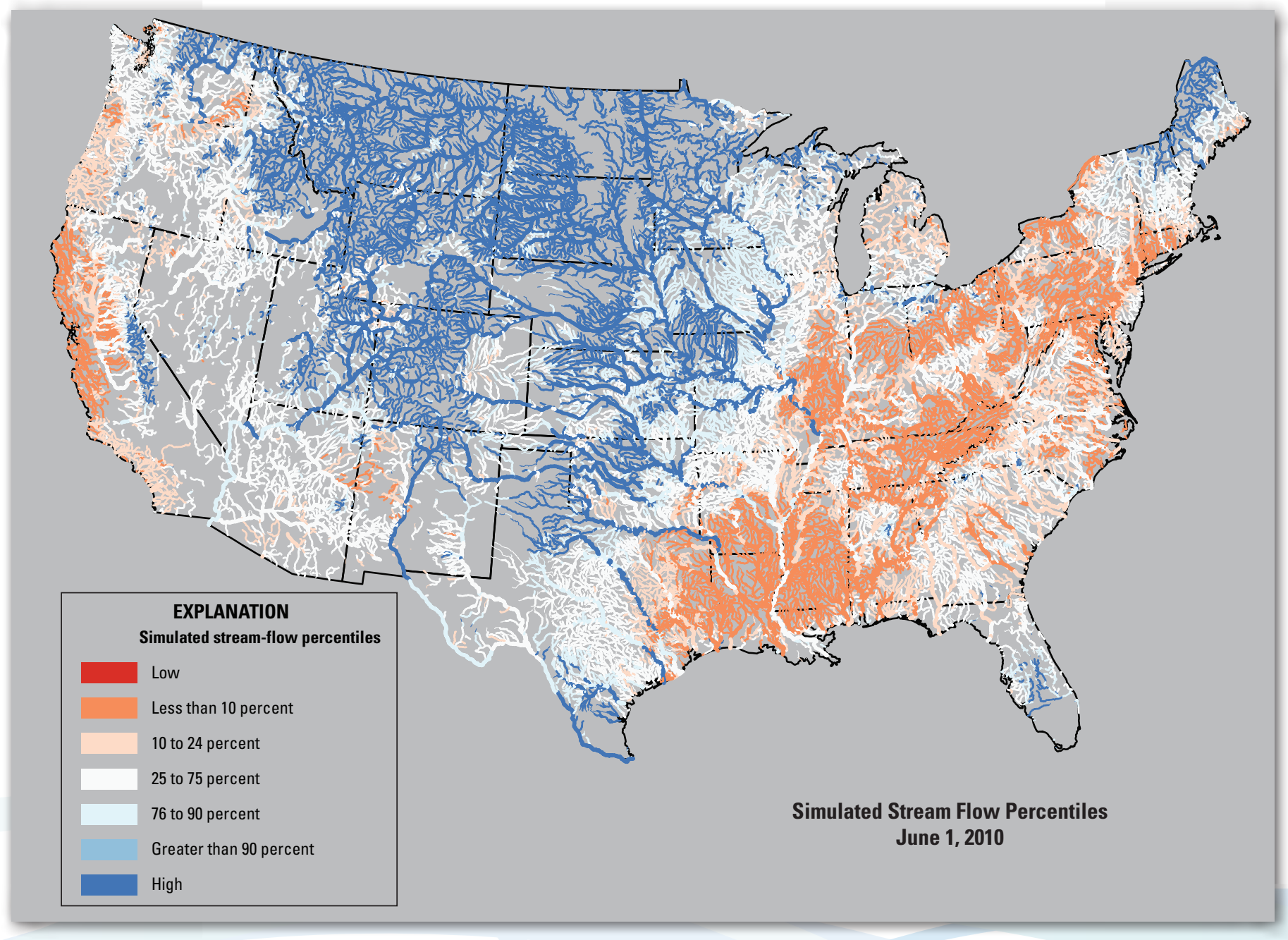

Figure 13. U.S. Geological Survey National Hydrologic Model-Precipitation Runoff Modeling System simulated streamflow for June 1, 2010, using the default parameters and model setup described in Regan and others (2018) and Driscoll and others (2017). The colored stream reaches show the flow percentile in each reach relative to simulated flow throughout the 1980-2010 simulation period for that day of the year. 
studies of low flow in Hawaii will provide information on the limits of the streamgage network for transferring information to ungaged locations in the islands

For all models, the uncertainty in the modeled streamflow varies widely depending on the region. Accurate characterization of uncertainty can improve water-resource decision making, and quantification of these uncertainties is a critical next step in this work.

\section{Analysis of Change in Streamflow}

A second major activity of this component of the Water Census is to evaluate trends in streamflow over time. Changes in surface-water hydrology can result from a wide variety of causes, including changes in water-management strategies, land-use changes, and climate variability or change. Changes in hydrology can affect water availability for public supply, industry, power generation, or agricultural use, and can affect water quality and aquatic ecosystems. Characterizing trends in streamflow and developing a greater understanding of the causes of trends are therefore critical to understanding future water availability and conducting effective water-resources planning.

Many studies are based on streamgages included in two USGS products: the HydroClimatic Data Network (HCDN) (Slack and Landwehr, 1992; updated in Lins, 2012) and the GAGES-II dataset (Falcone, 2011). The HCDN designates a set of streamgages as suitable for study of the effects of meteorological conditions on streamflow. The GAGES-II dataset similarly designates a set of streamgages as being of "reference" quality, whose upstream watersheds are least disturbed by human modifications and diversions. GAGES-II also provides a set of basin characteristics that can be used for further analysis. Continued maintenance of a national dataset of such gages is necessary to allow scientists to efficiently conduct studies to detect and understand streamflow change. An update of the GAGES-II dataset is planned within the next several years.

Analyses of streamflow records have revealed temporal changes in some aspects of flow. For example, many river basins that are snow-dominated in winter have shown a shift toward earlier spring runoff peaks associated with snowmelt (Stewart and others, 2005; Hodgkins and Dudley, 2006; Dudley and others, 2016). Studies analyzing trends in the magnitude of peak flows have been less conclusive, with the most recent USGS publications showing that the largest detectable changes may be in smaller, more frequent flooding events rather than the largest, most catastrophic events (Hirsch and Ryberg, 2012; Hirsch and Archfield, 2015; Hodgkins and others, 2017b). These and other potential changes to streamflow resulting from various causes are the subject of continuing research. USGS analysis and data have been used in the EPA's suite Climate Change Indicators (https://www.epa.gov/climate-indicators/climate-change-indicators-streamflow). These indicators are intended to show whether water-managementrelevant variables are changing over time.
Because streamflow is highly variable, analyzing trends in streamflow records is difficult. Moreover, changes in many different characteristics of flow may be important to different water managers or to different local ecological communities. For example, changes in seasonality of flow or day-to-day variability in flow may be just as important as shifts in annual mean streamflow, depending on the storage available in a particular water-resource system. Still other flow characteristics may be important for other specific purposes or concerns. Future studies will need to consider these factors and their effects on water management and water availability. USGS is also conducting work to better understand the causes of observed trends, which may arise from human modifications to upstream land use, river channels, and water management or water use, or from climate variability or change.

\section{Groundwater}

Any national assessment of water availability requires an assessment of the Nation's groundwater reserves. The Water Census has leveraged a long history of groundwater studies and applied resources to accelerate ongoing regional studies to achieve this goal. These groundwater assessments provide consistent and integrated information that enables the resource to be viewed and understood on aquifer-wide scales that cross political boundaries.

\section{Regional Groundwater Evaluations}

For 2010, USGS estimated that groundwater was the source of 37 percent of water withdrawn for public supply, 43 percent of water withdrawn for irrigation, and more than 98 percent of water withdrawn for self-supplied domestic use (Maupin and others, 2014). Groundwater is especially important during periods of climatic drought because in many areas it is used as backup supply when reservoirs or rivers cannot meet demands. The USGS has long recognized the importance of groundwater to provide water resources to the Nation and has historically reported to the U.S. Congress and the Nation on the status of groundwater resources (Meinzer, 1923; McGuiness 1951, 1963; Sun and Johnston, 1994; Johnston, 1999). In 2004, a program of regional groundwater availability studies was initiated under the former Groundwater Resources Program (Reilly and others, 2008). These studies are built around the estimation of groundwater budgets (Healy and others, 2007) for principal aquifer systems and typically quantify the response of the system to changes in pumping and variations in climate. In 2009, the Water Census funded an assessment of the glacial aquifer system, a principal aquifer system present in parts of 26 northern and midwestern states, and, in 2016, the regional groundwater availability studies from these programs were brought under the Water Availability and Use Science Program (WAUSP). The regional groundwater availability projects deliver information required for sound environmental decision making. 
A recently completed regional groundwater availability study illustrates the information delivered through this effort (Masterson and others, 2016). The Northern Atlantic Coastal Plain aquifer system is one of the Nation's smallest principal aquifers by area, but it is 7th largest in terms of population served and 13th largest in overall groundwater use. In additional to industrial and agricultural uses, it supplies drinking water for 40 percent of the population in the region, which extends from Long Island, New York, to northeastern North
Carolina and from the Atlantic Ocean westward to the Fall Line, where the Coastal Plain sediments abut the Piedmont Physiographic Province. Results of this study highlight two opposite responses of aquifer systems to pumping (fig. 14). In the northern part of the study area-Long Island, New York, for example - pumping has not produced large declines in groundwater levels because the aquifer system is shallow and well connected to surface water, including streams, lakes, and the ocean. In this part of the study area, pumping reduces the

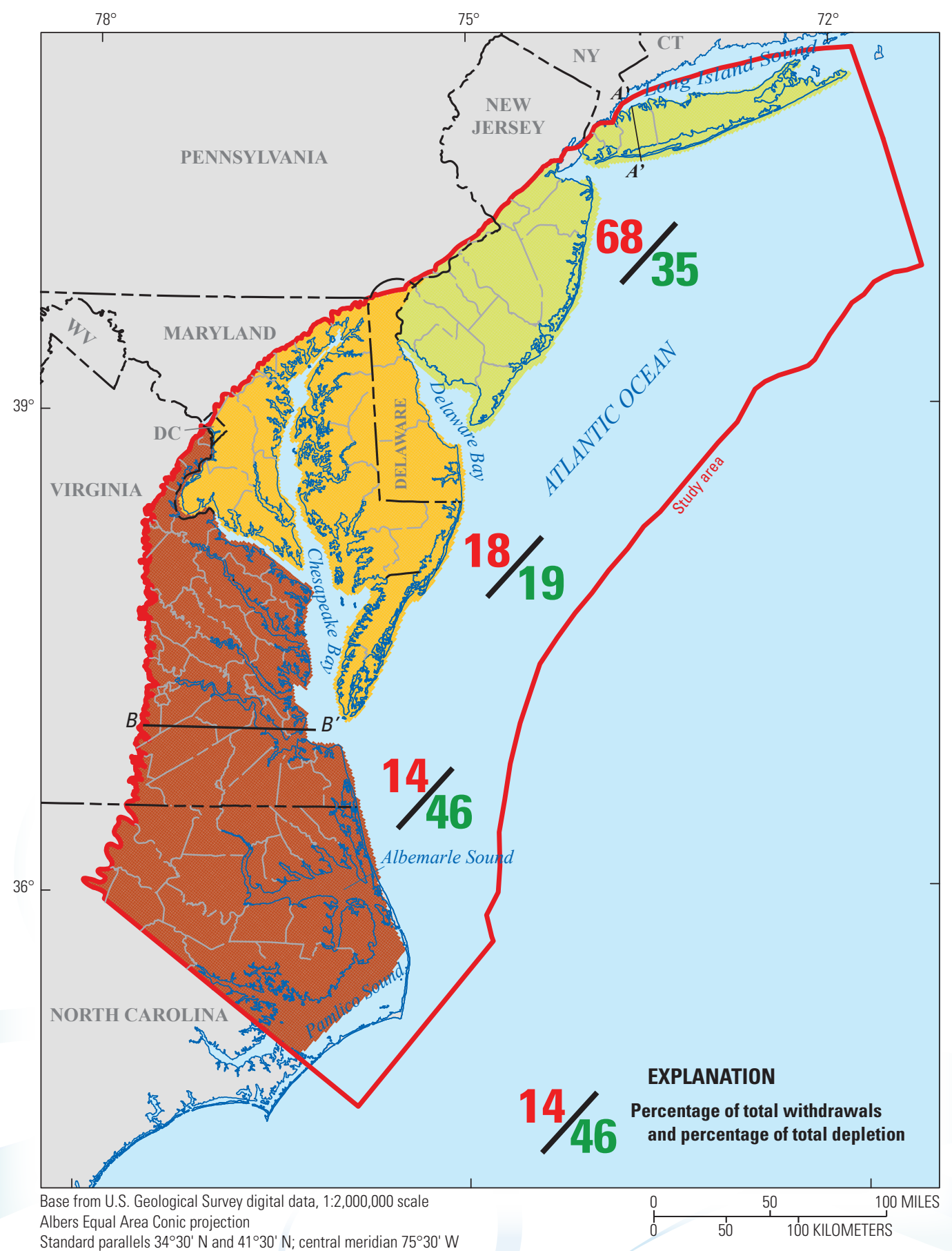

Standard parallels $34^{\circ} 30^{\prime} \mathrm{N}$ and $41^{\circ} 30^{\prime} \mathrm{N}$; central meridian $75^{\circ} 30^{\prime} \mathrm{W}$ North American Datum of 1983
Figure 14. Northern Atlantic Coastal Plain aquifer system cumulative groundwater withdrawals (27.8 trillion gallons (Tgal)) and storage depletion (2.2 Tgal) as percentage of total water withdrawn and percentage of total groundwater depletion from 1900 to 2013. (From Masterson and Pope, 2016, fig. 7) 
flow of groundwater to these surface-water features. In the southern part of the study area, including Virginia and North Carolina, the aquifers are deep and separated from streams and lakes by layers of material that impede groundwater flow. Consequently, pumping in this part of the system has produced large declines in groundwater levels. These declines can cause seawater to migrate into the aquifer, as well as land subsidence that may exacerbate the effects of sea-level rise on coastal communities.

The principal aquifer studies have examined the response of the systems to development and variations in climate, and through this work USGS is developing an understanding of how groundwater systems are responding to these drivers. The studies also are examining trends in groundwater levels across the country. More work is required to complete a national assessment, but example results from the Appalachian Plateaus (McCoy and others, 2015) and the glacial aquifer system (Hodgkins and others, 2017a) illustrate how longterm streamflow and groundwater data are being used to help understand the processes of the aquifer systems. Streamflow data may be analyzed to determine the component of the flow attributed to groundwater, base flow, and runoff from the land to the stream. Three sets of runoff and base flow time series show how individual stations may show little trend (fig. 15A),

\section{A. 03051000 Tygart Valley River at Belington, WV}

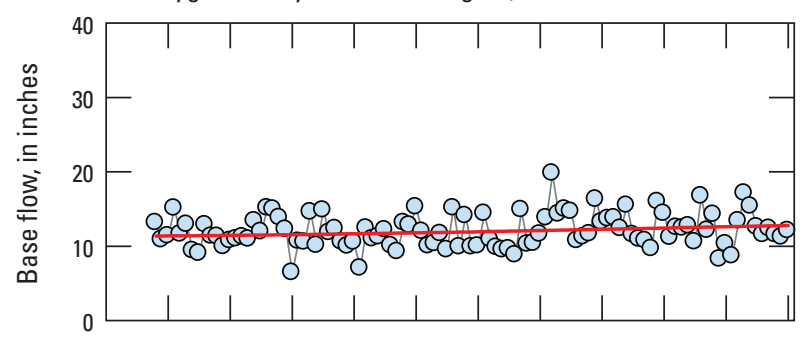

B. 03208500 Russell Fork at Haysi, VA

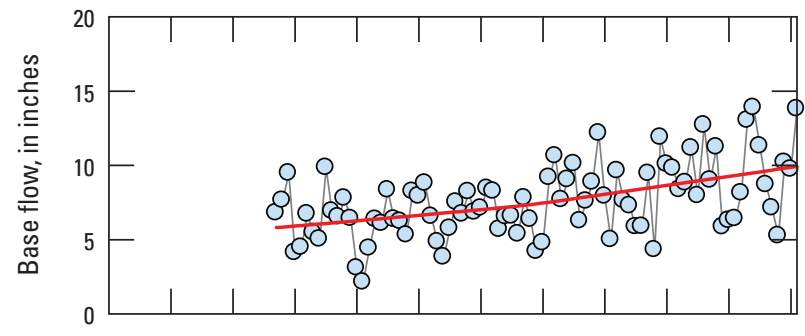

C. 03118500 Nimishillen Creek at North Industry, $\mathrm{OH}$

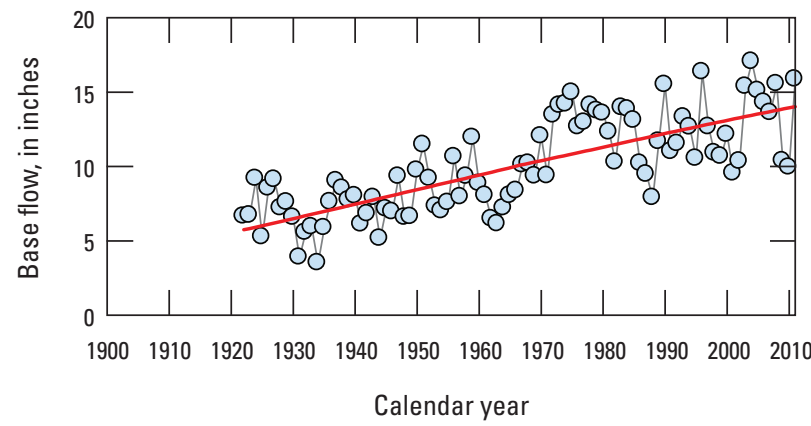

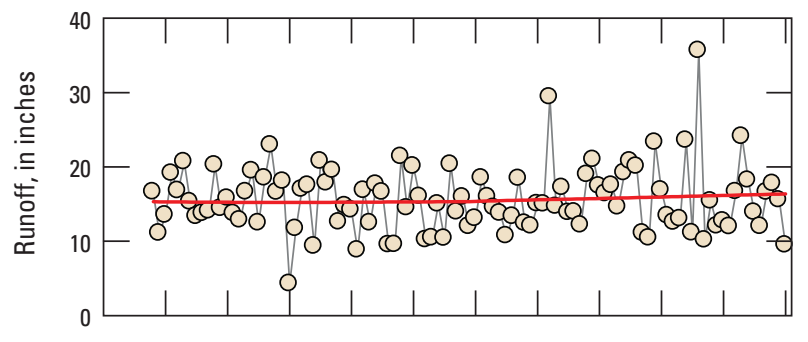
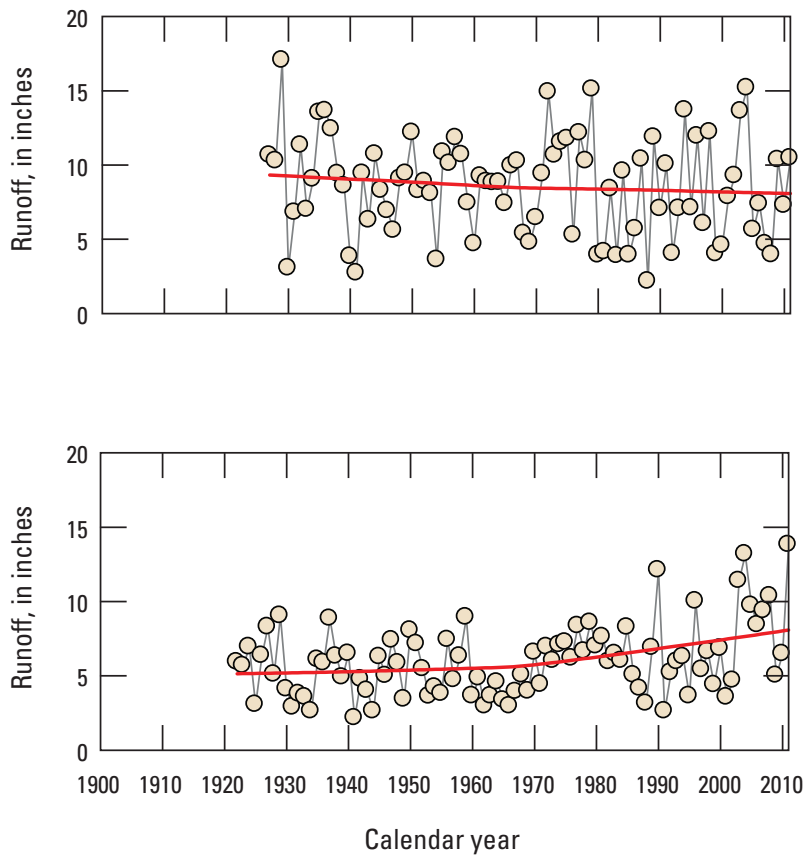

EXPLANATION

Loess lines

Figure 15. Time series of annual values of base flow and runoff at U.S. Geological Survey streamgaging stations $A, 03051000$ Tygart Valley River at Belington, W.Va.; B, 03208500 Russell Fork at Haysi, Va.; and C, 03118500 Nimishillen Creek at North Industry, Ohio. (Modified from McCoy and others, 2015, fig. 34) 
may show increases in base flow with little change in runoff (fig. 15B), or may show increases in both base flow and runoff (fig. 15C). Differences in behavior among these three stations has been attributed to the combined influence of climate and land-use change over the period 1920-2010 (McCoy and others, 2015). Groundwater-level data for wells in the glacial aquifer system east of the Rocky Mountains were examined for trends (fig. 16). Mostly positive trends are noted in the Northeast, indicating rising groundwater levels. In other parts of the system, wells show both positive and negative trends and many trends are significant if no underlying persistence in the data is assumed (Hodgkins and others, 2017a). Hodgkins and others (2017a) discuss these trends and the underlying nature of the data.

\section{Composite Hydrographs}

At the present time (2017), there are no regularly updated indicators for the Nation's groundwater resources. In response to this need, the USGS developed "composite hydrographs" for many of the principal aquifers in the United States, utilizing groundwater-level measurements made by the USGS and available publicly in the National Water Information System (NWIS, https://waterdata.usgs.gov/nwis). A composite water level is a statistical representation of an average water level computed from multiple wells within each principal aquifer. There are currently 23 principal aquifers for which composite hydrographs have been calculated and are available to the public through the USGS Groundwater Watch webpages (https:// groundwaterwatch.usgs.gov/compositehome.asp).

The composite hydrographs may be used by local stakeholders who may be interested in whether the behavior of water in a local well is consistent with the average behavior of water in wells in the larger aquifer system. They also may be compared to other regional data to explore how the system is responding to climate or pumping. For example, the water level in the composite hydrograph of the Northern Atlantic Coastal Plain (NACP) principal aquifer is steadily decreasing, perhaps in response to the large increase in groundwater withdrawals from 1940 to 1980 (fig. 17A). Wet and dry years

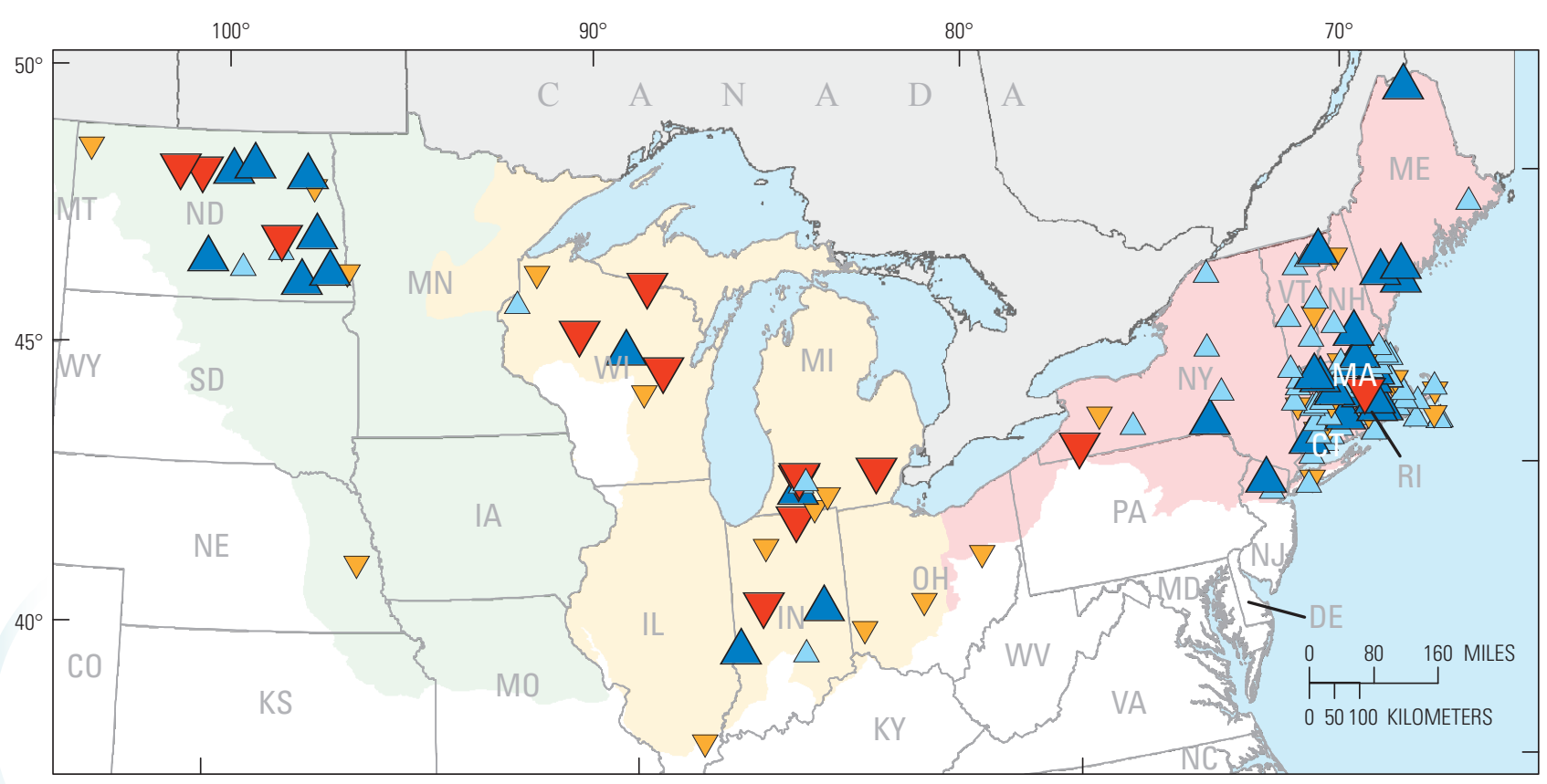

Basemap of states from U.S. Geological Survey, 1:2,000,000, digital data

Albers Equal-Area Conic projection, standard parallels $29^{\circ} 30^{\prime}$

and $45^{\circ} 30^{\prime}$, central meridian $-96^{\circ}$, latitude of origin $23^{\circ}$

EXPLANATION

East Region

Central Region

West-Central Region
Trend ( $p$ is less than or equal to 0.05 )

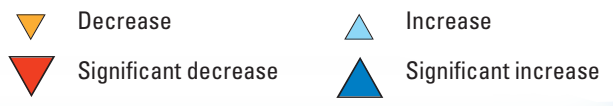

Figure 16. Geographic distribution of trends in mean annual groundwater levels, 1984-2013 with the assumption of data independence. (Modified from Hodgkins and others, 2017b) 
as indicated by the Palmer Drought Severity Index (PDSI) also appear to lead to small increases or small decreases, respectively, in the median composite water level, as shown in figure $17 B$, which uses the NACP wells for Virginia and the PDSI for Virginia (National Oceanic and Atmospheric Administration National Centers for Environmental Information, 2017). In contrast to the slow decline in water levels in the NACP, the composite hydrographs for the Coastal Lowlands principal aquifer show an increase in water levels (fig. 18A,B). Examination of the pumping records and the PDSI for Texas (National Oceanic and Atmospheric Administration National Centers for Environmental Information, 2017) indicates that the increase in groundwater levels is associated with a decrease in pumping in the greater Houston, Texas, area, which underwent large shifts in water use from groundwater to surface water beginning in 1976 in Harris and Galveston Counties (for pumping data and more information, see Kasmarek and Johnson, 2013). The recovery in the median composite water levels ceased in 2010 and water levels started to decline, presumably in response to severe drought conditions in the region from 2011 to 2015. Finally, the California Coastal Basins composite hydrographs appear to be strongly related to wet and dry conditions in California as indicated by the PDSI (National Oceanic and Atmospheric Association National Centers for Environmental Information, 2017). The median composite water level in these wells falls during times of drought and recovers during wet periods (fig. 19). These varying responses to the combined effects of climate and pumping from principal aquifers as indicated by the median composite water level show why groundwater-flow modeling as described in the preceding section (Regional Groundwater Evaluations) is so important. Through regional models, hydrologists can test hypotheses regarding the reasons for observed aquifer system responses and make predictions regarding system responses to future changes. This information can help water managers and stakeholders make informed decisions regarding groundwater-resource development (see Box C).
$\boldsymbol{A}$

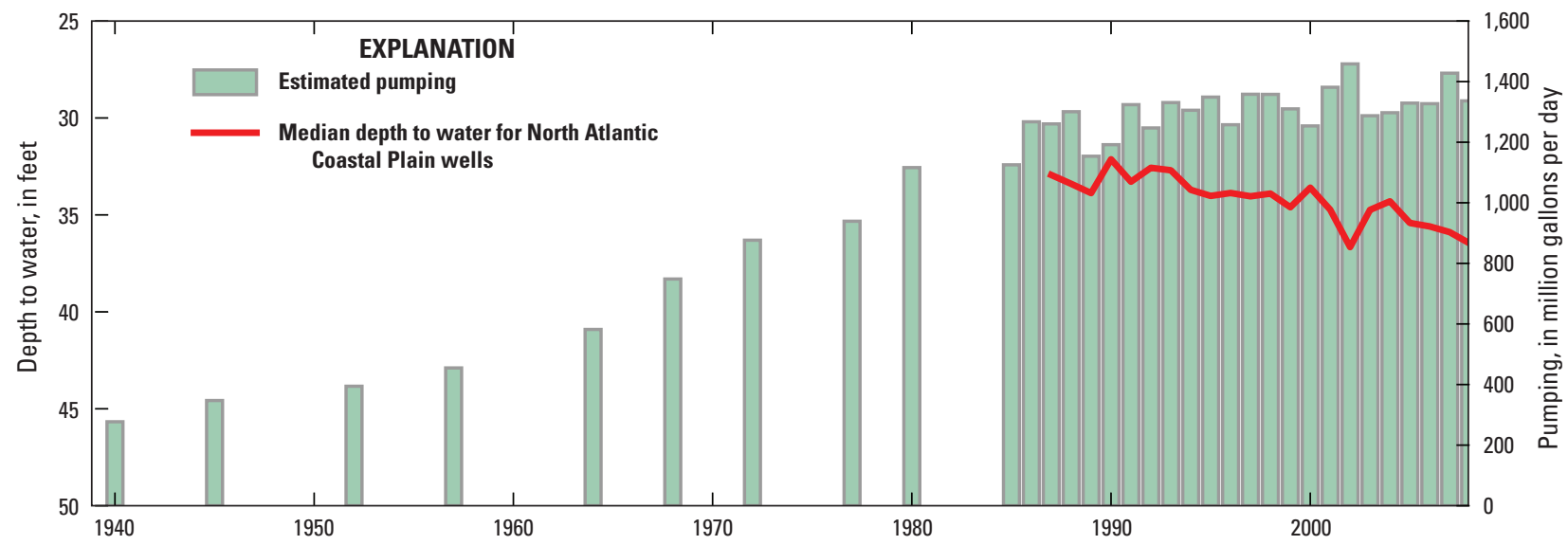

B

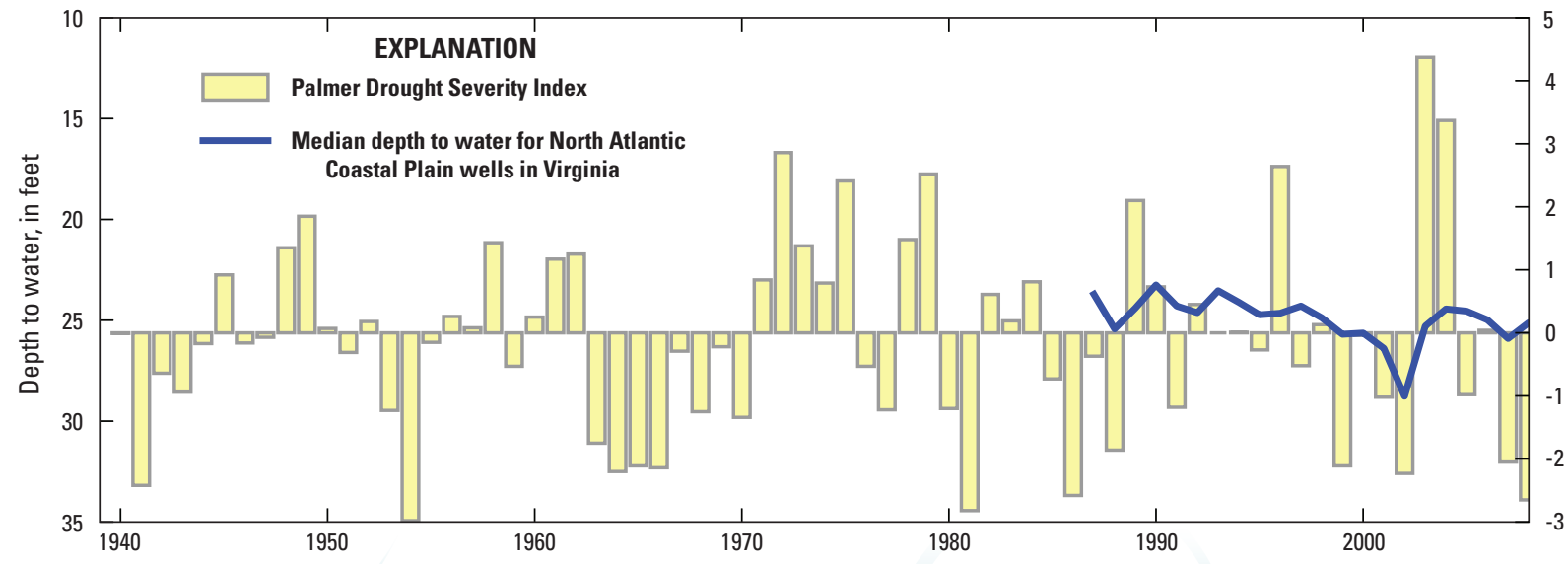

Figure 17. Composite hydrograph and associated hydrologic information for the North Atlantic Coastal Plain principal aquifer, 1940-2010. 
A

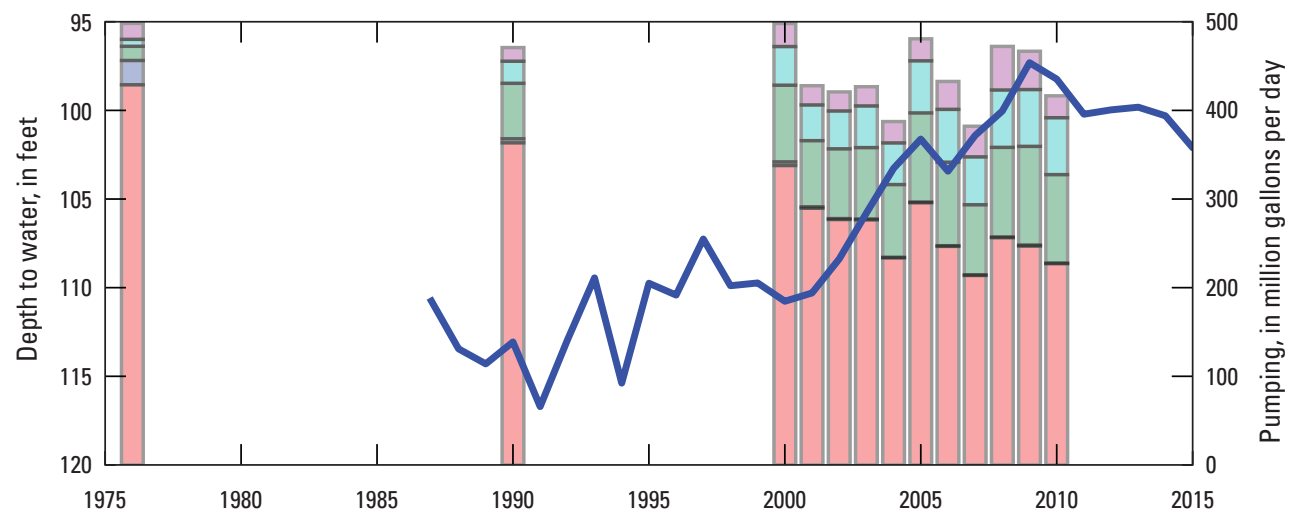

$\boldsymbol{B}$
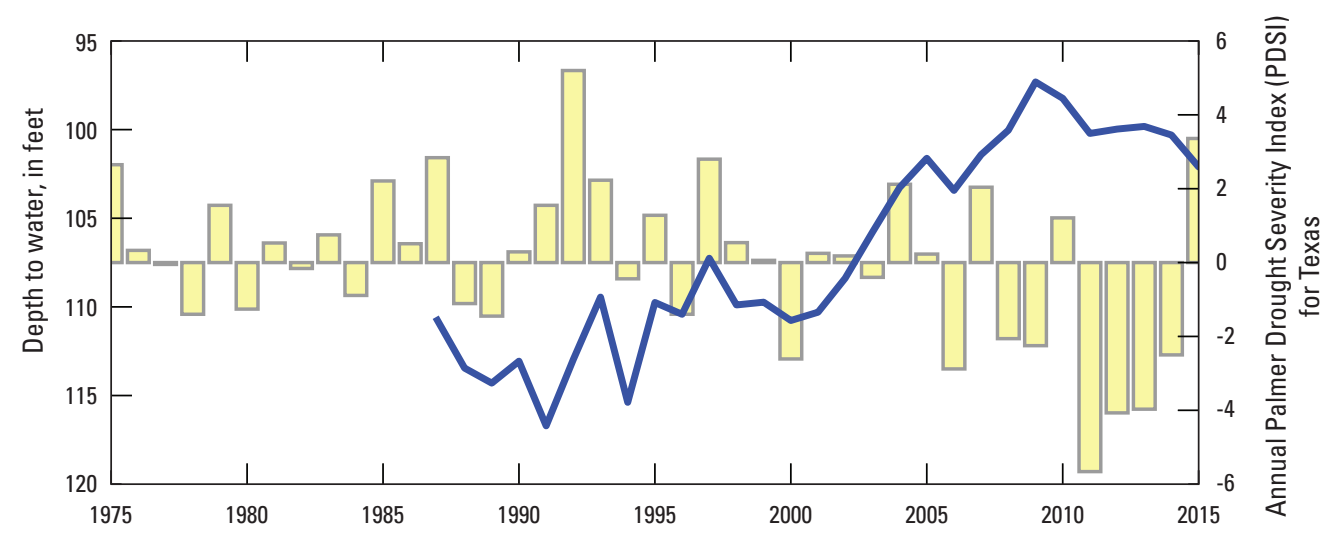

EXPLANATION

Pumping, by county

Brazoria County

Montgomery County

Fort Bend County

Galveston County

Harris County

Palmer Drought Severity Index for Texas

Median depth to water

Figure 18. Composite hydrograph and associated hydrologic information for the Coastal Lowlands principal aquifer, 1975-2015.

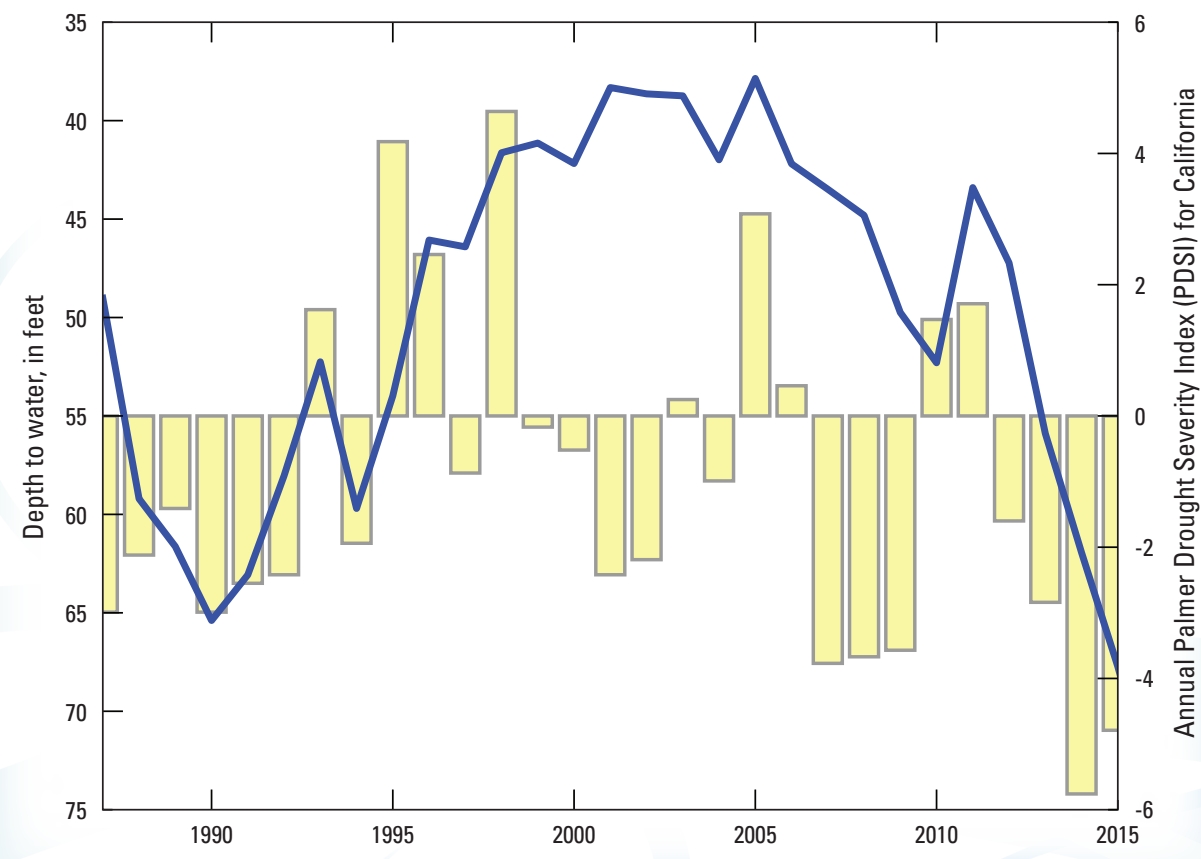

EXPLANATION

Palmer Drought Severity Index for California

Median depth to water

Figure 19. Composite hydrograph and associated hydrologic information for the California Coastal Basins principal aquifer for the period 1985-2015. 


\section{Box C. Testimonial}

66The USGS report, "Volcanic Aquifers of Hawai'i-Hydrogeology, Water Budgets, and Conceptual Models" is a valuable summary of the current knowledge of Hawai'i's groundwater, and a source for updated estimates of groundwater recharge and water use. The USGS recharge estimates are an essential component of the aquifer sustainable yields developed by the State of Hawai'i Commission on Water Resource Management as part of the Water Resources Protection Plan of the Hawai'i Water Plan., g,

-Jeffrey Pearson, Deputy Director, Hawai 'i State Commission on Water Resource Management

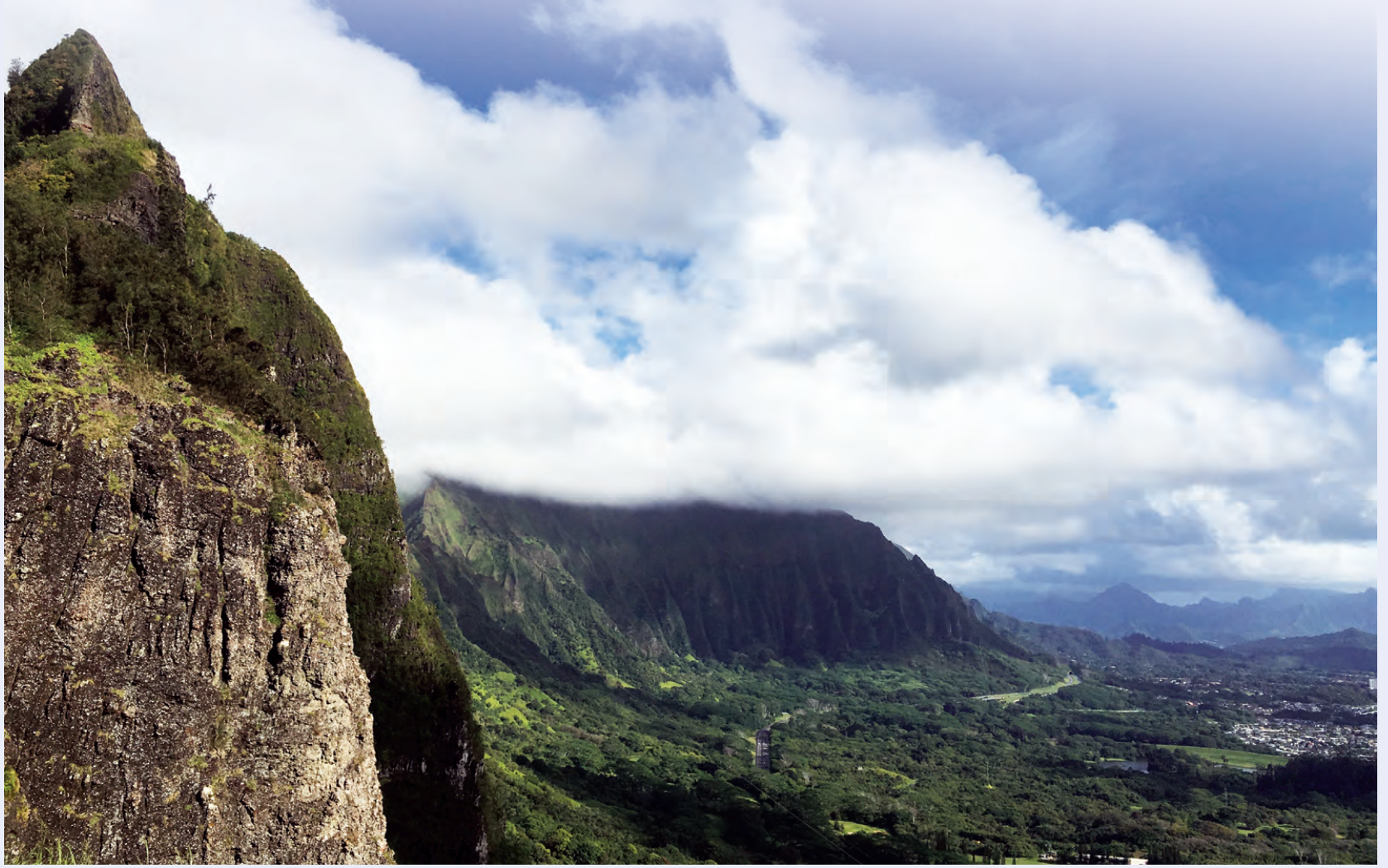

Nu'uanu Pali Lookout, Oahu, Hawai'i. Photograph by Alan Cressler, U.S. Geological Survey. 


\section{Tools for Groundwater Availability—Model Sustainability}

The primary tool used for quantitative analysis of regional groundwater systems is numerical modeling. Numerical models provide a holistic representation of the water-budget components of the Nation's principal aquifers and enable forecasting of the responses of groundwater resources to future stress from groundwater development, land-use change, and climate variability (Dennehy and others, 2015). For more than 50 years, the USGS has been a leader in the development and application of numerical modeling software for analysis of groundwater systems, and has made a long-term commitment to the development and maintenance of modeling software and ancillary tools that support the Water Census, the National Water Quality Assessment Project, and other USGS programs. The USGS also has developed a robust training program for its staff and other Federal, State, Tribal, and local partners in the use of its modeling software.

USGS software continually evolves to incorporate advances in hydrologic research and computer technology into operational tools that can better address the complex, interdisciplinary nature of water availability (see Box D). During the past 5 years, the USGS made advancements in many of its numerical modeling software, including its flagship groundwater-simulation code MODFLOW. Named "MODFLOW 6," the code has been redesigned to provide greater flexibility to simulate regional- and local-scale groundwater systems simultaneously and for improved integration with other types of watershed, chemical-transport, and water-operations models (Hughes and others, 2017; Langevin and others, 2017). This new multiscale modeling approach will be a key component of the recently initiated groundwater-availability study of the

\section{Box D. Testimonials}

${ }^{6} 6$ The MODFLOW suite of codes is the most widely used set of groundwater codes in the world and the standard for litigation purposes in the United States. MODFLOW has been applied to numerous and diverse field problems and is the focus of a series of international professional conferences (http://igwmc.mines. edu/Conference.html).,

-Anderson and others, 2015 (p. 100-101)

66MODFLOW gained broad acceptance because it is a versatile, well tested, well documented, and in the public domain.,

-Fitts, 2013 (p. 360)
Coastal Lowlands aquifer system extending along the Gulf Coast from South Texas to the western part of the Florida panhandle. Advancements also have been made to the water-quality simulation capabilities of MODFLOW (Bedekar and others, 2016), which are needed to improve understanding of the suitability of groundwater resources for human and ecosystem needs. The Water Census also supported the application of the Soil-Water Balance software (Westenbroek and others, 2010) to various parts of the country and the Groundwater Toolbox (Barlow and others, 2014) to better quantify groundwaterbudget components such as recharge and discharge to streams. These codes have been applied to several of the regional studies, including the High Plains (Stanton and others, 2011, 2013), Appalachian Plateaus (McCoy and others, 2015; Nelms and others, 2015) and glacial (fig. 20) aquifer systems. The USGS has also continued development of software tools to aid scientists in the process of building, calibrating, and visualizing model results (Welter and others, 2015; Bakker and others, 2016; White and others, 2016), and to link hydrologic models with water-resource management and operations models (Ahlfeld and Barlow, 2013; Morway and others, 2016; Niswonger and others, 2017; White and others, 2018).

\section{Increasing Access to Groundwater Information}

In 2015, Congress provided increased funding to the USGS to address groundwater sustainability through open access to groundwater information, on the basis of work proposed through the White House Office of Science and Technology Policy and as required by the 2016 USGS Public Access Plan (U.S. Geological Survey, 2016). Through the Water Census, the USGS has enhanced access to its groundwater models and borehole geophysical logs. Implementation of consistent and standardized approaches for archiving and public release of USGS models and geophysical data makes these important and valuable products accessible, discoverable, and usable by USGS scientists, cooperators, academia, and the public, and illustrates the leadership provided by the USGS in this area.

Since 1993, the USGS has required that groundwater models developed as part of USGS studies be archived and made available to the public upon request. These requirements ensure that the data and related information that compose the models remain available to support and validate model results reported in USGS publications, and that working versions of all models are available for future scientific use. During FYs 2016 and 2017, the USGS developed an approach and webpage to assist USGS scientists in the public release of groundwater models on the DATA.GOV cataloging site (https://catalog.data.gov/dataset? $\mathrm{q}=$ usgsgroundwatermodel), including the release of several completed regional groundwater-availability studies; work also continues on the development of methods to display model results through USGS web pages. During FY 2017, the USGS publicly released "GeoLog Locator" (https:// webapps.usgs.gov/GeoLogLocator/\#!/) (fig. 21), which is a web-accessible, map-based viewing and retrieval tool to 


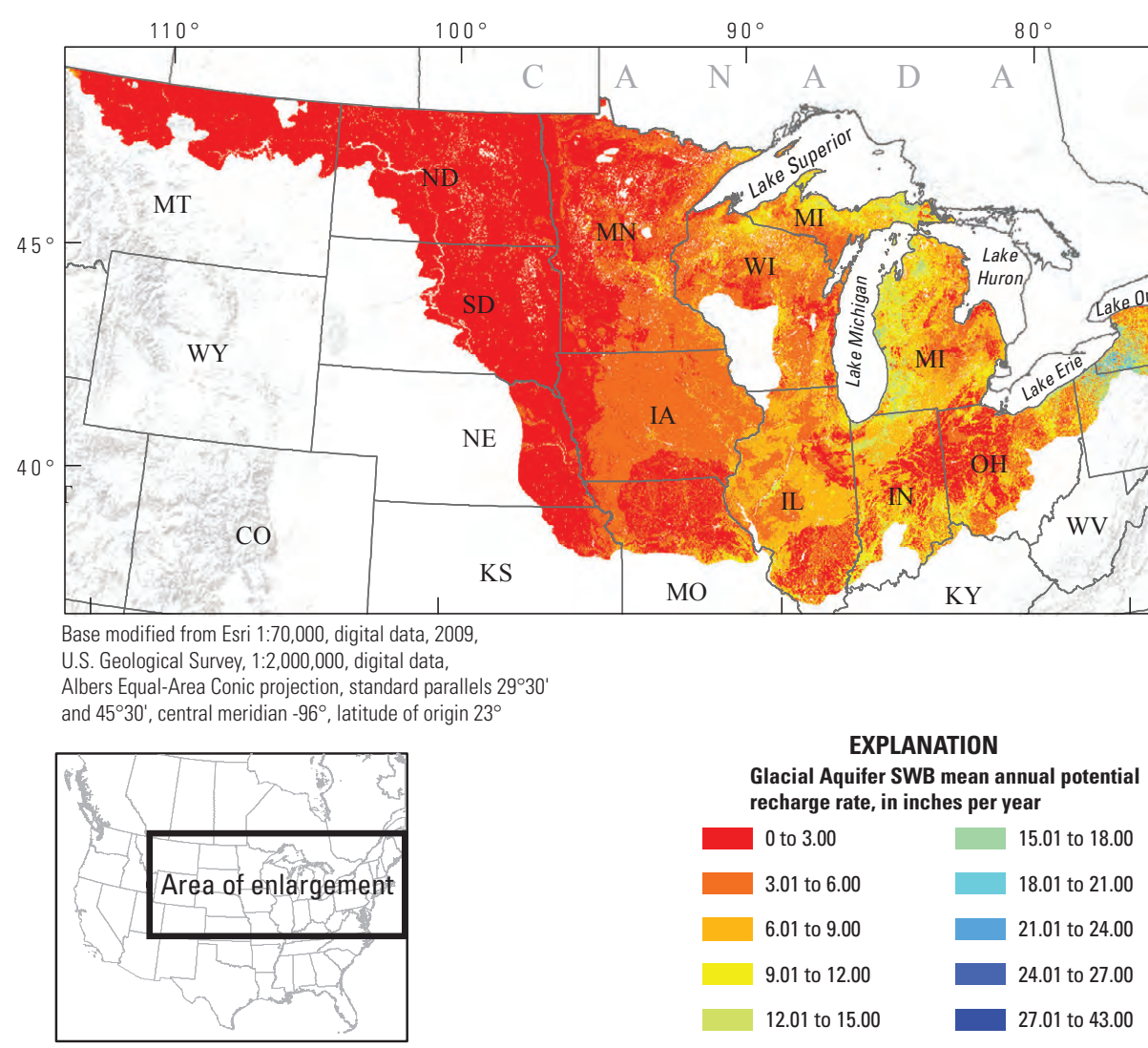

Figure 20. Preliminary long-term average (1980-2011) groundwater-recharge rates estimated for the glacial aquifers of the United States by use of the U.S. Geological Survey (USGS) Soil-Water-Balance (SWB) model as part of the USGS Glacial Aquifers Groundwater-Availability Study. Recharge rates are lowest in the western United States (red and orange areas) and generally increase eastward (yellow and green areas). (Modified from Westenbroek and others, 2010)

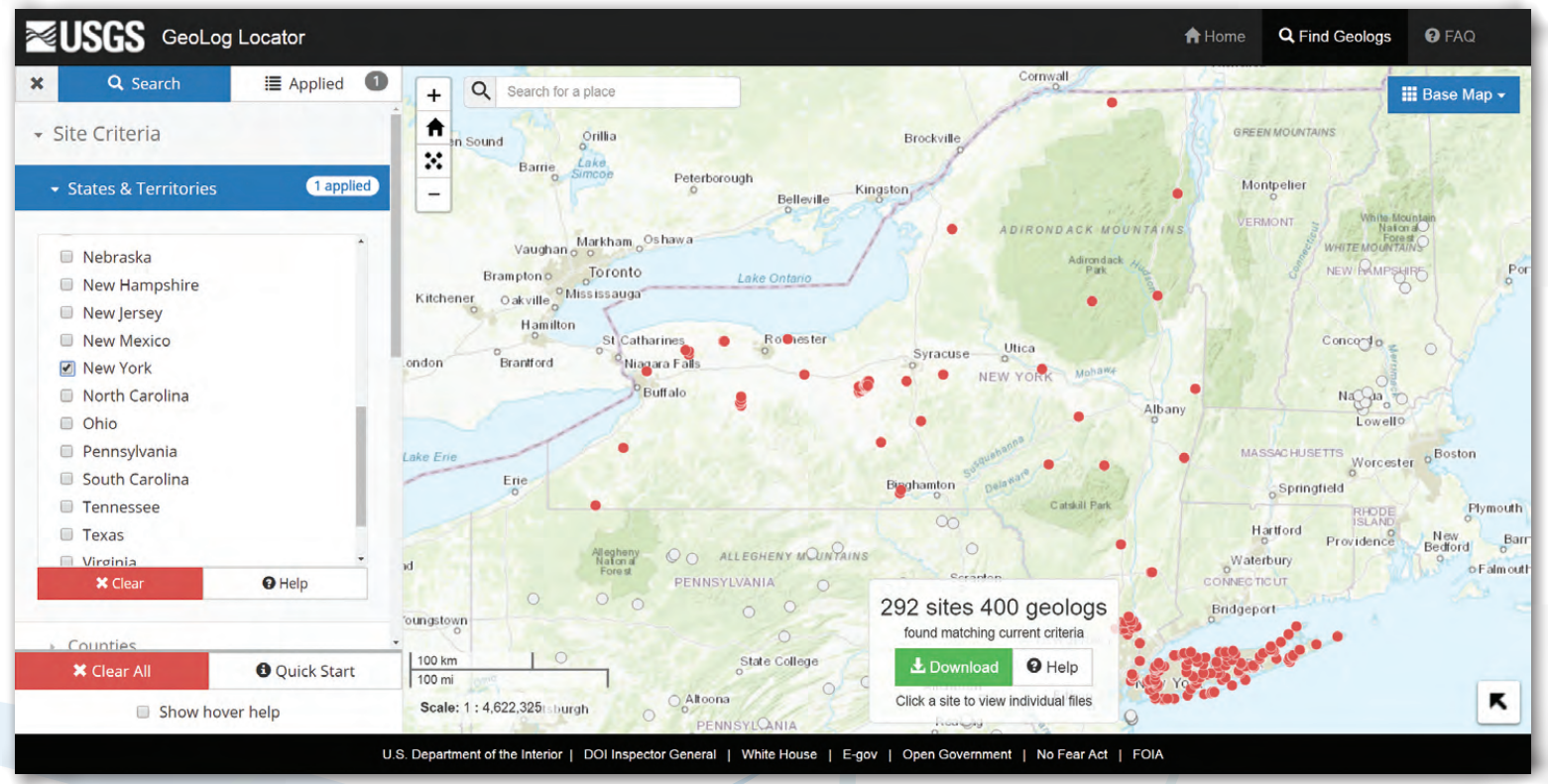

Figure 21. Sites in New York State for which borehole-geophysical logs are available through the U.S. Geological Survey GeoLog Locator. (From U.S. Geological Survey, 2017e) 
publish USGS borehole geophysical logs. The initial release of GeoLog Locator provides the public with access to nearly 7,000 geophysical logs - many for the first time. The application uses underlying data from nearly 17,000 logs stored within an internal database, and provides the necessary review and approval flags to assure the proper workflow for publication of the data.

\section{National Groundwater Monitoring Network}

The SECURE Water Act, Section 9507, provided legal authority for the USGS to implement the National GroundWater Monitoring Network (NGWMN). The NGWMN was developed through the efforts of the Advisory Committee on Water Information (ACWI, https://acwi.gov/), Subcommittee on Groundwater (SOGW, https://acwi.gov/sogw/index.html). The goal of the NGWMN is to integrate groundwater-level and groundwater-quality data collected by Federal, State, and local agencies to address groundwater availability questions at the principal aquifer scale (https://water.usgs.gov/ogw/aquifer/ map.html).

The SOGW created a design for the NGWMN in the document "A National Framework for Ground-Water Monitoring in the United States" (https://acwi.gov/sogw/ngwmn framework_report_july2013.pdf). In 2009, five pilot studies were conducted to test the concepts of the proposed network. As part of the pilot effort, a NGWMN Data Portal was developed to share NGWMN data, and feedback from the pilot participants was used to update the original network design described in the Framework document. Information about the NGWMN and links to the NGWMN Data Portal are available at https://cida.usgs.gov/ngwmn/.

After successful piloting, Congressional funds were appropriated in FY 2015 to support implementation of the NGWMN. These initial funds allowed 11 states to become new data providers to the NGWMN, or to complete work initiated during the pilot studies. A summary of the projects supported during FY 2015 are available at https://cida.usgs. gov/ngwmn/doc/NGWMN_FY15_ProjectSummary.pdf. A competitive process for future funding opportunities for data providers was initiated in FY 2015, and the National GroundWater Monitoring Network Program Board was formed to assist in evaluation of NGWMN proposals, as recommended in the Framework document. The NGWMN Program Board is composed of data providers, Federal agencies, and SOGW members. In FY 2016, support was provided to 24 agencies to become new data providers or to improve or enhance their existing NGWMN sites. This collaborative funding approach increases the number of data providers, increases the number of groundwater-level and groundwater-quality sites in the NGWMN, reduces data gaps, and improves the overall quality of data supplied by NGWMN data providers. A summary of the projects supported during FY 2016 are available at https:// cida.usgs.gov/ngwmn/doc/NGWMN_FY16_ProjectSummary.pdf. In 2017, awards were made to 19 State agencies. A summary of the projects supported during 2017 is available at https://cida.usgs.gov/ngwmn/doc/NGWMN_FY17_ProjectSummary.pdf.

To date (2017), these projects have resulted in NGWMN growth from the 5 pilot project data providers in 2014 to 19 current data providers, with current projects supporting an additional 12 agencies working to become NGWMN data providers. The NGWMN has also supported data providers to maintain their connection to the Portal and enhance data available from their network wells. The number of wells in the NGWMN has increased from 2,831 groundwater-level sites in early 2015 to 5,792 sites in July 2017 . The number of groundwater-quality sites has increased from 534 in early 2015 to 1,325 in July 2017.

The SECURE Water Act also authorized the USGS to expand the groundwater Climate Response Network (PL 11111, Sec 9507 (b)(3)(B)) into each of the 373 Climate Divisions in the United States and its territories. The Climate Response Network (CRN) provides near-real-time, continuous groundwater levels in wells and springs designed to monitor the effects of droughts and other climate variability on groundwater levels. Expansion began with the appropriation received in FY 2015. As of 2017, Federal funds have supported instrumentation of 200 wells and springs, and instrumentation of 33 additional sites is in progress.

\section{Brackish Groundwater}

Secure, reliable, and sustainable water resources are fundamental to the Nation's food production, energy independence, and ecological and human health and well-being. At any given time, water resources are under stress in selected parts of the country. In some regions, particularly arid and semiarid regions, water supply is not adequate to meet demand, and severe drought intensifies the stresses affecting water resources. If drought conditions continue, water shortages could adversely affect human health, economic well-being, and minimum water flows necessary to maintain ecosystem health. These risks can potentially be mitigated, at least in part, by developing new water-supply sources.

Advances in desalination technology and increases in demand for uses that do not need high-quality water (for example, mining, oil and gas development, and thermoelectric power generation) have led states such as Texas and California to turn to brackish groundwater as an alternative to freshwater. Brackish water refers to water that contains more dissolved salts and minerals than freshwater, but less than seawater (dissolved-solids concentration between 1,000 and 10,000 milligrams per liter $[\mathrm{mg} / \mathrm{L}])$. Brackish groundwater resources can potentially meet many water-resource needs. Identification of new sources of brackish groundwater, especially in areas with limited freshwater resources, has the potential to enhance the Nation's water security. In some areas, the use of brackish groundwater could reduce effects on freshwater resources commonly used for drinking, business, 
and recreational activities. The strategic development and treatment of brackish groundwater to produce new water supplies for a variety of uses could help water-stressed regions stretch their limited freshwater supplies. The use of brackish groundwater, however, has been hampered by the lack of basic knowledge concerning its geographic distribution, accessibility, chemical composition, use, treatment requirements, and effects on the environment.

The USGS completed the National Brackish Groundwater Assessment to provide updated information about brackish groundwater as a potential resource to augment or replace freshwater supplies. For the national brackish groundwater assessment, brackish groundwater was quantitatively defined as having a dissolved-solids concentration between 1,000 and $10,000 \mathrm{mg} / \mathrm{L}$. Study objectives were to consolidate available data into a comprehensive database of brackish groundwater resources in the United States and to produce a summary report highlighting the distribution, physical and chemical characteristics, and use of brackish groundwater resources. The assessment is contained in U.S. Geological Survey Professional Paper 1833 entitled, "Brackish groundwater in the United States" (Stanton and others, 2017). This assessment was authorized by section 9507 of the Omnibus Public Land Management Act of 2009 (42 U.S.C. 10367), passed by Congress in March 2009. Funds supporting the assessment were appropriated in FYs 2012 through 2017 and totaled \$2.2 million over that time.

This new assessment builds on a 1965 study (Feth, 1965) which, for more than five decades, has served as the primary source of information on the national distribution of brackish groundwater. By incorporating data from more than 380,000 sites, compared to about 1,000 for the 1965 study, the 2017 assessment provides more comprehensive, nationwide data on the quantity and quality of brackish groundwater across the country. This compilation includes information such as the chemical composition of the water and the amount of water yielded by wells, which are necessary for understanding the potential — at the National and regional scales - for expanding brackish groundwater development and for informing decision and policy makers.

Data from the assessment indicates that brackish groundwater can be present at some depth within 3,000 feet below land surface in every state except New Hampshire and Rhode Island. A conservative estimate for the volume of brackish groundwater underlying the country is more than 35 times the amount of fresh groundwater currently used each year (Stanton and others, 2017). Consequently, it is reasonable to consider brackish groundwater a substantial water resource available for use by the Nation.

In addition to limitations caused by high concentrations of salts and minerals, the presence of other chemicals can have important implications for the feasibility, treatability, and associated cost of using brackish groundwater. The study identified specific chemicals in brackish groundwater that require specialized treatment beyond that required to reduce overall salt content.
Despite the availability of this new information, there is still more to uncover on sustainable development of brackish groundwater. For many locations, data have not been collected for depths greater than $500 \mathrm{ft}$. The next challenge with regard to possible development of brackish groundwater is to acquire detailed information for specific aquifers that contain brackish groundwater, which is needed to evaluate sustainable brackish groundwater development, including the effects of brackish groundwater withdrawals on adjacent water resources. This assessment could be accomplished through the compilation of additional existing data, collection of new data, and use of additional tools for evaluating these potential resources.

\section{Evapotranspiration}

Evapotranspiration (ET) is the upward flux of water from the land surface to the atmosphere, and is a combination of evaporation from the soil and transpiration by plants. An essential component of water-budget determinations for water availability, ET is also a fundamental variable of water use, especially for irrigation, and has important implications for administration of water rights and river-basin compacts. Historically, reliable estimation of ET required site-specific field measurements made by using specialized instruments. However, because these measurement sites represent conditions only in their immediate vicinity, quantifying ET over broad areas such as irrigation districts, river basins, or states is a difficult task. Substantial progress has been made in meeting this challenge by using remote sensing to make estimates of ET across the landscape. USGS is applying its satellite remote-sensing resources and expertise to quantify ET for the Water Census by developing and implementing the Operational Simplified Surface Energy Balance Model (SSEBop) (Senay and others, 2013).

A new ET dataset has been constructed from these data for the entire conterminous United States (Senay and others, 2013). Although temperature data are collected daily by satellite, energy-budget calculations are made on 8-day composite images to reduce problems of cloud cover. These results, in turn, are accumulated into monthly, seasonal, and annual summaries of ET from 2000 to 2015. Crop water use has been estimated by using this dataset along with geographic information system (GIS) layers and remote-sensing imagery for identification of irrigated cropland (Savoca and others, 2013). Monthly and annual GIS layers (2000-15) are posted at the USGS Geo Portal site at https://cida.usgs.gov/gdp/. Anomalies in recent ET for the conterminous United States are also available online to assist with water management and drought monitoring (https://earlywarning.usgs.gov/useta/etaseasonal. php; see fig. 22).

Water-use reporting (irrigation consumptive use) requires estimates of actual ET (ETa) at the scale of agricultural fields. USGS Landsat thermal infrared imagery, with a resolution of 60 to 120 meters (197 to $394 \mathrm{ft}$ ), was used for this purpose in the Colorado River Basin (Senay and others, 2016). Results 


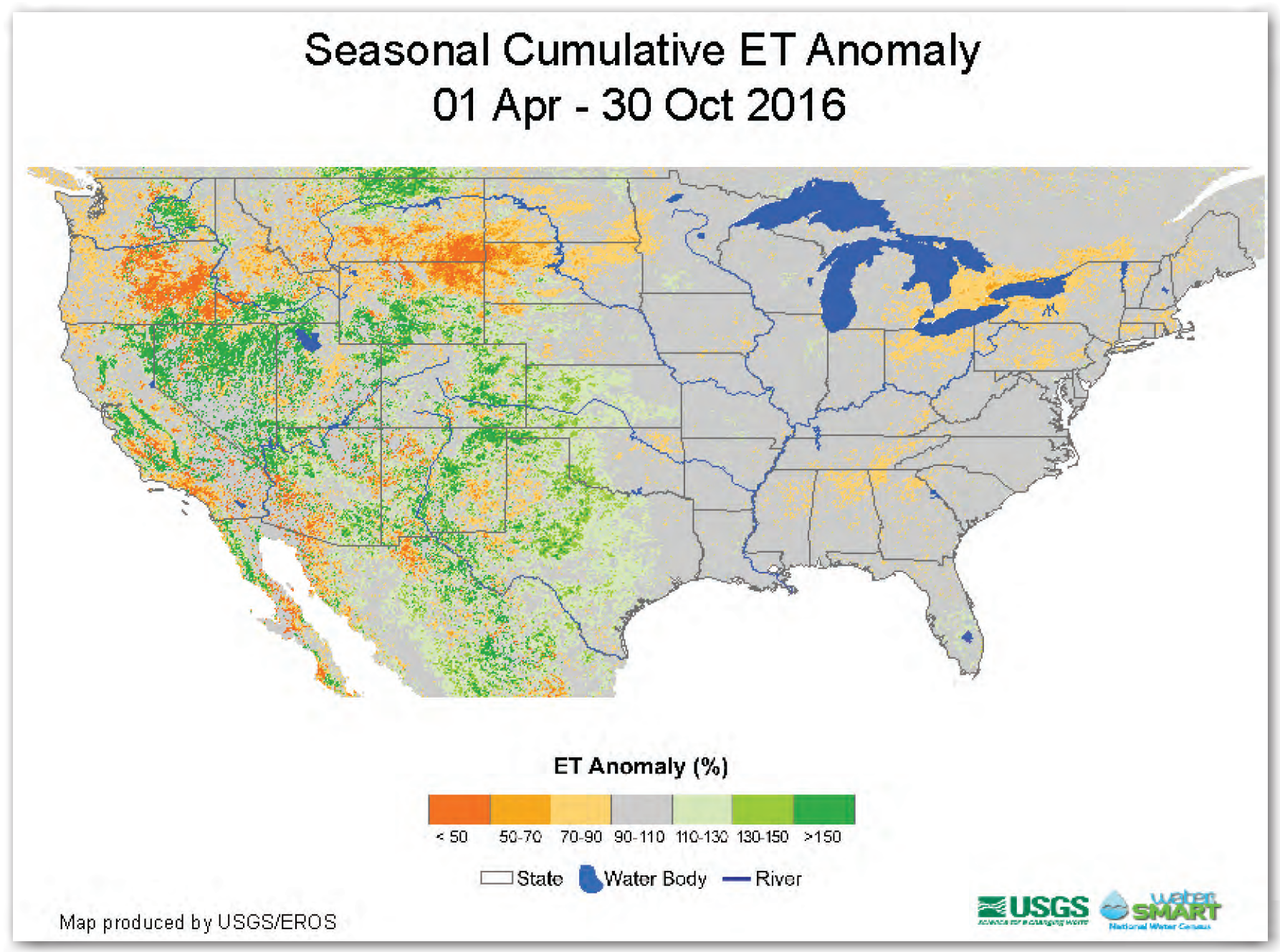

Figure 22. Seasonal cumulative evapotranspiration anomaly for the conterminous United States, April 1-0ctober 30, 2016. (From U.S. Geological Survey, 2017d)

are available for one complete year at a monthly time step. Application of Landsat data to ET estimation has been completed for four additional Focus Area Studies - the Delaware, ACF, Rio Grande, and Red River Basins. Stakeholders have shown a strong interest in using these detailed estimates. With the experience gained from these studies, along with enhanced computing power, USGS is preparing to estimate ET at the Landsat scale for the entire conterminous United States. This new dataset will be available online within a few years. Future work will also include improved parameterization for complex terrain and uncertainty estimation.

The California Department of Water Resources and other stakeholders participating in the National Integrated Drought Information System (NIDIS, https://www.drought. gov/drought/what-nidis) California pilot study led by NOAA identified information on fallowed land as being particularly important to understanding effects of drought on water use. In response, USGS developed the Fallow-land Algorithm based on Neighborhood and Temporal Anomalies (FANTA) to quantify fallowed-land extent by using remote-sensing imagery (Wallace and others, 2017). The FANTA method compares current greenness and historical greenness of individual pixels derived from satellite imagery to classify land as fallowed. Fallowed land assessment is an important tool for state water resource agencies, enabling them to more accurately assess the need for irrigation water in the current year. The method was applied to the State of California for 2001-15, with verification by field visits to more than 450 sites in 2014. Work is ongoing to extend the method for use in other irrigationdependent agricultural regions of the United States.

\section{Water Use}

The SECURE Water Act places direct emphasis on assessment of the use of surface water and groundwater for understanding the demand side of water availability. As further evidence of the interest in water use by the U.S. Congress, 
Section 9508 (d) (3 and 4) places specific reporting requirements on the USGS with regards to water use. Improved information is needed on withdrawal, conveyance, consumptive use, and return flow by sector of use as well as on the factors that influence these components of water use. Such information will allow water managers and planners to make more effective decisions for the future.

The term "water use," in a restrictive sense, refers to water that is withdrawn by humans for a specific purpose, such as public supply, irrigation, or thermoelectric-power cooling. More broadly, water use pertains to the interaction of humans with and their influence on the hydrologic cycle, and includes elements such as water withdrawals, delivery, consumptive use, wastewater release, reclaimed wastewater, return flow, and instream use. The term "water withdrawals" in this report refers to the removal of water from a groundwater or surfacewater body that is subsequently put to a beneficial use.

In addition to the many accomplishments that follow, in 2016, the USGS developed an interactive data visualization that shows freshwater-use by state every 5-years from 1950 to 2010 (https://owi.usgs.gov/vizlab/water-use/). This tool allows users to discover the most comprehensive national-scale data on water use for the United States. The USGS compiles and estimates this water-use information in cooperation with State, Federal, and local agencies. The visualization presents estimates by categories including public supply, irrigation, and thermoelectric power. The visualization highlights how water use differs from one part of the country to another. Water withdrawal for thermoelectric power generation are most prominent in the eastern half of the United States while irrigation water use is dominant in the west. The data and software for the visualization are publicly available and open source.

\section{Water-Use Compilation 2015}

Every 5 years since 1950, the USGS has compiled a national estimate of water use by various categories and areas for the United States, the District of Columbia, Puerto Rico, and the U.S. Virgin Islands. The 2015 compilation is the 14th report in this series and provides the most comprehensive assessment of water withdrawals from available resources (groundwater and surface water; fresh and saline) for eight categories of use: public supply, domestic, irrigation, livestock, aquaculture, industrial, mining, and thermoelectric power. This product, however, is the first since 1995 to also include consumptive use for two of the largest categories of use, irrigation and thermoelectric power. In 2016 and 2017, the USGS made a deliberate effort to rapidly issue available information on 2015 water use. Through this effort, public supply withdrawals, domestic water use, and total population information for 2015 were released both as a USGS Open-File Report (Dieter and Maupin, 2017; https://doi.org/10.3133/ ofr20171131) and a data release (Dieter and others, 2017; https://doi.org/10.5066/F7TB15V5) in October of 2017. These products documenting water use in 2015 represent the most rapid data release possible given the project capabilities. The national totals and trends report is produced when data for all categories have been approved and summarized.

Data are compiled and synthesized using local, State, and Federal data sources, as well as data provided by the National Water Use Science Project (NWUSP). These data are checked and verified, then entered into the USGS Aggregated Water Use Database System (AWUDS), which has the capability to store data by area (State, county, watershed, and aquifer), and year for each state. Data required for the compilation are reported at the county level as annual average withdrawals in million gallons per day. The AWUDS database is the source of the data available online at USGS Water Data for the Nation (http://waterdata.usgs.gov/nwis), which displays the best available water-use data from AWUDS.

The 5-year compilations present water-use statistics, aggregated by county, state, and the entire country for the target year, for all eight categories of water use (public supply, domestic, irrigation, livestock, aquaculture, self-supplied industrial, mining, and thermoelectric power). In addition, the compilation presents an analysis of trends in water use from 1950 through the target year for each category. The most recent published compilation as of the time of this report is "Estimated Use of Water in the United States in 2010" (Maupin and others, 2014). By presenting this information, the compilations fulfill two of the major reporting requirements of the SECURE Water Act, sections 9508 (d) (3 and 4), relating to the withdrawal and use of surface water and groundwater by various sectors and the significant trends relating to each water-use sector.

\section{Water-Use Data and Research Program}

The SECURE Water Act, Section 9508 (c), provided legal authority for the USGS to establish the Water Use Data and Research Program (WUDR). The overall goal of the WUDR is to improve water-use data (in the broad sense) for the United States by providing resources to State water-resource agencies or their designees, to improve their water-use information. This program will improve the accuracy of estimates of water use in the United States, and provide information needed to manage water resources and (or) forecast future water-use needs. Improved data will also allow the USGS, other agencies, scientists, and researchers to better understand which categories account for the most water, and work toward reducing the "footprint" of water use in the high-use categories.

Much of the data used to compile water-use estimates at the national level is reported to State agencies throughout the United States. The WUDR Program promotes cooperative work with State agencies by providing funding to them for improving water-use data collection, methods development, database development and data storage, and quality-assurance activities. Improvements at the State level will, in turn, improve estimates at the national level. WUDR cooperative agreements also require collaboration between State agencies 
and USGS offices nationwide by requiring data from funded projects be incorporated into USGS databases.

Between FY 2015 and FY 2017, 44 states, American Samoa, the District of Columbia, and the U.S. Virgin Islands each received $\$ 26,000$ through WUDR to describe current water-use information in each state or district, as well as the priorities for improving water-use information and possible approaches to addressing those priorities (fig. 23).

In FY 2016, 18 states (fig. 24) received WUDR funds totaling $\$ 1.4$ million through a competitive process to address priorities for improving water-use information. A list of states with project titles is available online at https://water.usgs. gov/wausp/wudr/awardsFY16.html. In FY 2017, 15 states (fig. 25) received WUDR funds totaling \$1.32 million through a second competitive process. A list of states with project titles and summaries is available online at https://water.usgs.gov/ wausp/wudr/awardsFY17.html. The projects in both FY 2016 and FY 2017 include improving database systems, improving reported data quality, and working to acquire more robust data.

The WUDR Program has led to many discussions between State agencies and USGS, both in the exchange of ideas with respect to which water-use data need to be improved, and in improved data sharing. Additionally, WUDR listening sessions were held in three locations across the United States (Salt Lake City, Utah; Chicago, Illinois; and Tuscaloosa, Alabama) in 2015; during those sessions, State agencies identified the need to share expertise among State agencies and the USGS. (Session notes are available online at https://water.usgs.gov/wausp/wudr/stakeholders.html). To address this need, a monthly webinar series, the USGS Water Use Open Forum (WUOF), began in February 2016, and since then 15 1-hour recorded sessions have been held (https://water. usgs.gov/wausp/wudr/wu-forum.html). The WUOF provides an excellent opportunity for State agencies to share information on all aspects of water-use data, from database systems to estimation methods, reported data, and so forth, with other states and the USGS. All of these aspects of the WUDR program actively build collaboration and cooperation between State agencies and the USGS.

\section{Thermoelectric Water Use}

Water withdrawals for thermoelectric-power generation, used predominantly in the cooling process, are the largest in the United States, accounting for 45 percent of total withdrawals in 2010. Historically, thermoelectric cooling water withdrawals have been reported by the Department of Energy's (DOE) Energy Information Administration (EIA) and state regulatory agencies with responsibility for thermoelectric generating plants. These agencies, however, have different reporting, methods, and data sources requirements, which have resulted in incomplete datasets, inconsistent water-use data, and uncertain data quality.

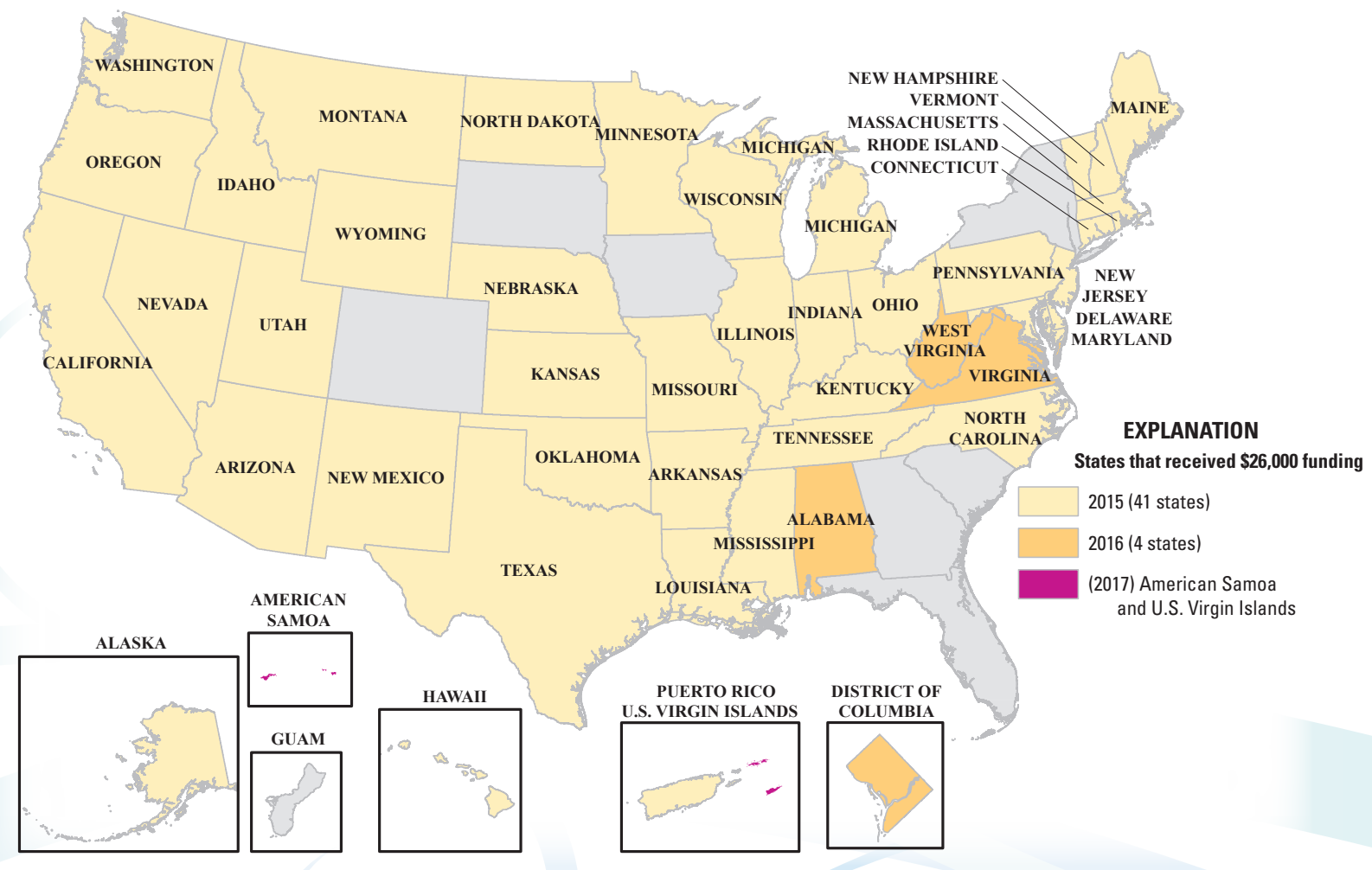

Figure 23. States that received funds $(\$ 26,000)$ from the Water Use Data and Research Program to describe current water use and identify priorities for improving water-use data in their state. 


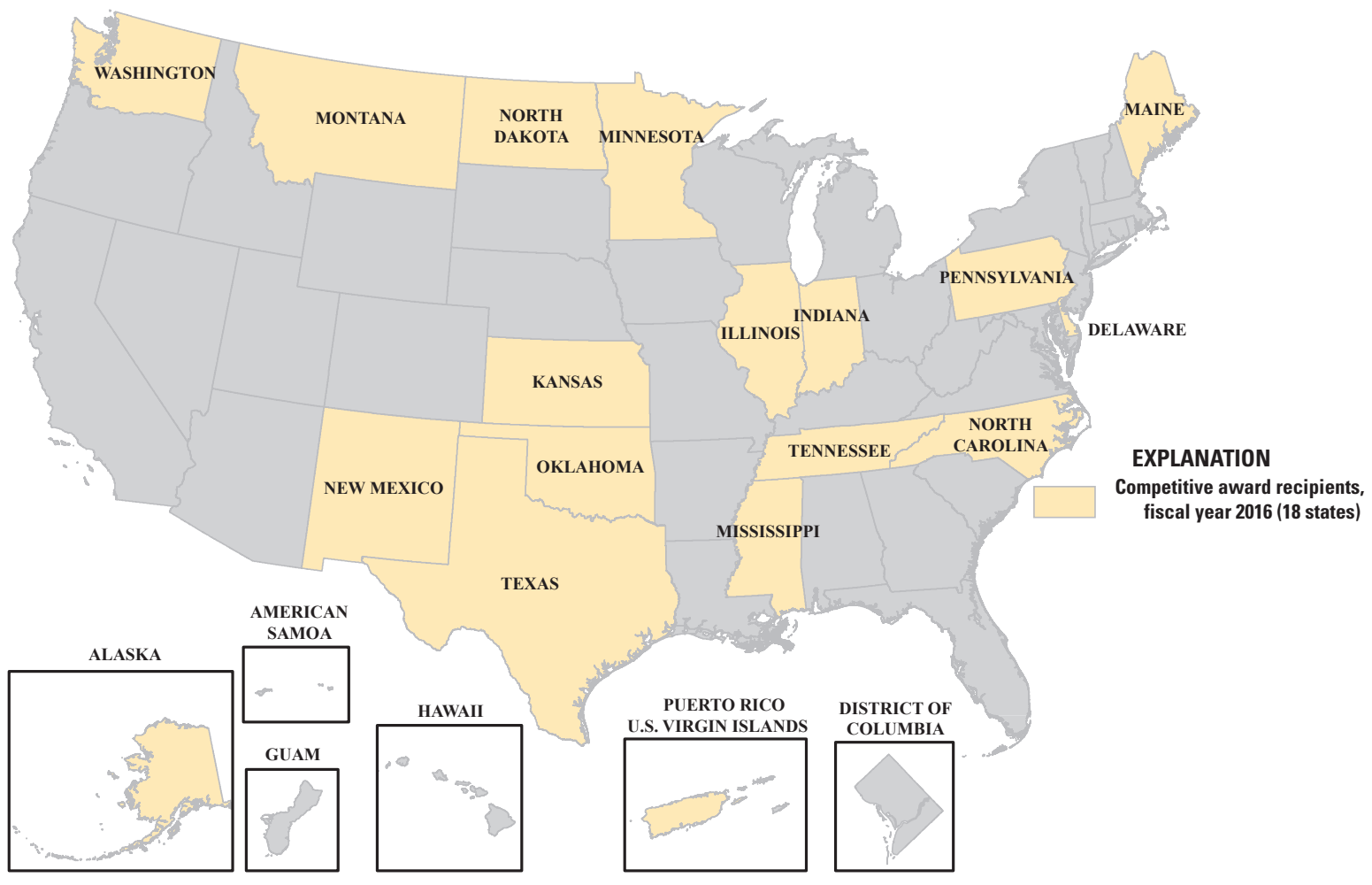

Figure 24. States that were awarded funds from the Water Use Data and Research 2016 Competitive Program to improve water-use data and research in their state.

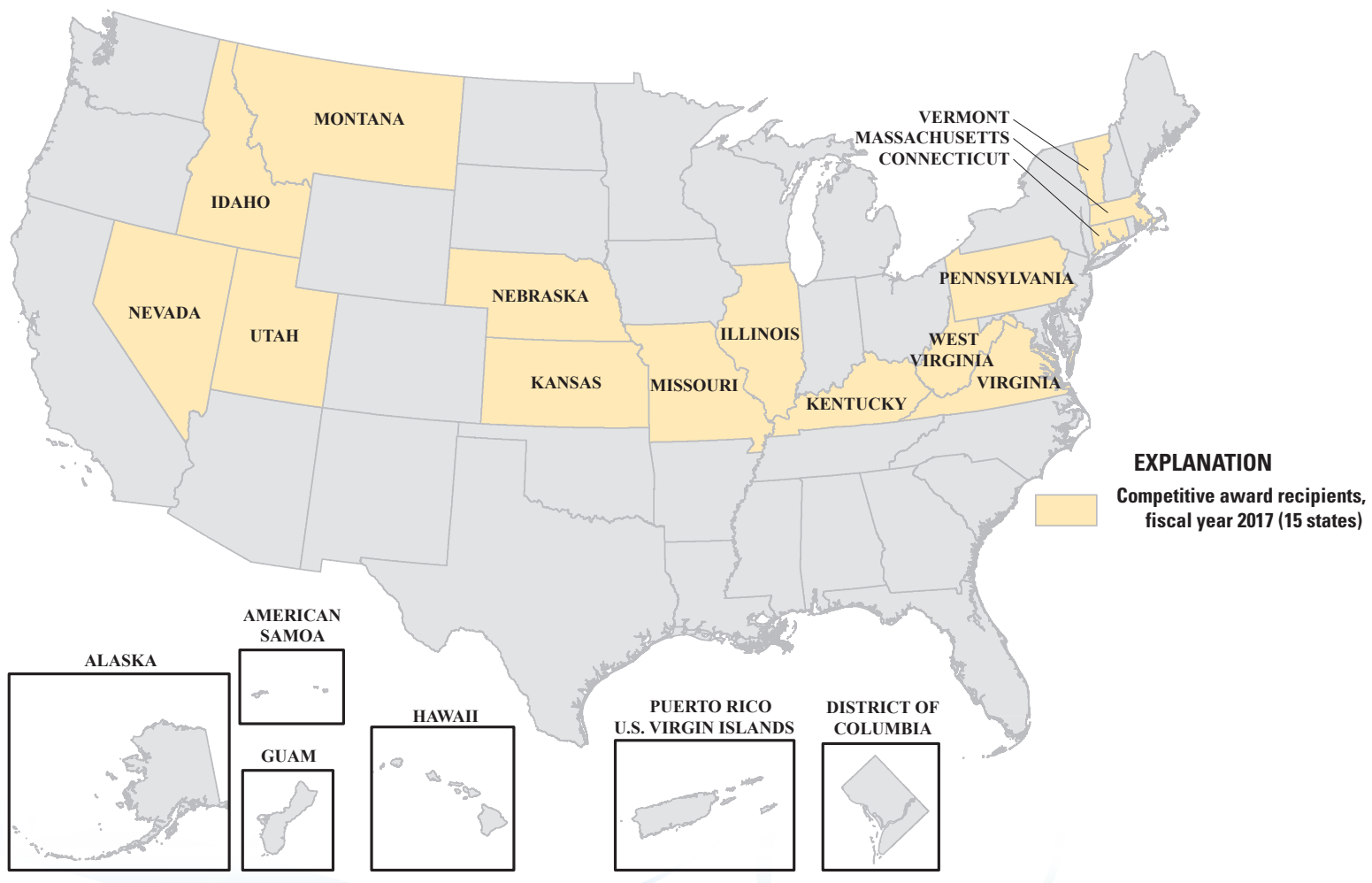

Figure 25. States that were awarded funds from the Water Use Data and Research 2017 Competitive Program to improve water-use data and research in their state. 
From FY 2011 to FY 2013 the USGS, in collaboration with the EIA, developed models for estimating thermoelectric water withdrawals that provide estimates that are independent from EIA plant-operator-reported data. The NWUSP, as part of the WAUSP, developed these models and has produced estimates of withdrawal and consumptive use for approximately 1,300 thermoelectric power plants in the United States to support the USGS 2010 and 2015 national water-use compilations. The models are based on linked heat-and-water budgets that are constrained by power-plant fuel consumption and electricity production, generation technologies, coolingsystem technologies, and environmental variables. The models provide a consistent method for estimating withdrawals and consumptive use across all plants in the United States. The methods for estimating thermoelectric consumptive use were published in Diehl and others (2013); the withdrawal methods plus the 2010 model estimates for withdrawals and consumptive use were published in Diehl and Harris (2014).

In addition to withdrawal and consumptive-use estimates, the models also provide thermodynamically plausible ranges of withdrawal and consumptive use for each plant, thereby providing a quality-assurance check for the EIA plant-operator-reported data, as well as for the USGS compilation data that may be obtained from State agencies and (or) plant operators. A journal article and associated data release product, which shows a three-way comparison among the 2010 USGS model estimates, the EIA-reported data, and the USGS compilation data, were published in Harris and Diehl (2017a,b).

USGS will continue to collaborate with EIA to improve reported data, which in turn improves the thermoelectric models. In 2016, EIA published a tool which allows users to relate boilers, generators, and cooling systems to one another at each plant. USGS requested this tool to enhance EIA data for the models. The tool greatly improved the models by more accurately mapping the heat path in a plant from fuel consumption to cooling system.

This research has resulted in continued collaboration among USGS, EIA, DOE, the national energy laboratories, and other Federal and State agencies on matters related to water and energy issues.

\section{Water Use by Principal Aquifer, 2015}

The Water Census has improved the understanding of groundwater resources with regional analysis of principal aquifers that collectively account for a majority of the Nation's total groundwater withdrawals (https://water.usgs. gov/ogw/gwrp/activities/gw-avail.html). However, groundwater studies continue to lack water-use data that satisfy needs at the regional and local levels. To fill these data needs, groundwater withdrawals reported for the USGS national compilation for 2015 will be used to estimate water use by principal aquifer for each county in the United States.
Sixty-six principal aquifers in the United States have been defined as regionally extensive aquifers, or aquifer systems, with the potential to be used as sources of water of suitable quality and quantity to meet various water needs (Maupin and Barber, 2005). In 2000, withdrawals from these principal aquifers were estimated for three major categories (public supply, self-supply industrial, and irrigation) that accounted for more than 98 percent of all groundwater withdrawals for all categories of use in the United States (Maupin and Barber, 2005). The 2000 estimates were reported as statewide totals by category and principal aquifer, which is a very broad and high-level scale assessment. For the new effort, a USGS team will use the 2015 county groundwater withdrawals by category, along with water-well records, aquifer maps, and other ancillary data, to estimate withdrawals by principal aquifer for each county for all major categories reported in the 2015 compilation. Along with the estimates, the team will develop and document a variety of methodologies and protocols for estimating withdrawals by principal aquifer that will cover a variety of situations related to data availability in a state. A long-term goal of the WAUSP is to report national groundwater use for all categories by principal aquifers at a high spatial and temporal resolution. This ongoing study is collaborating and coordinating data collection and reporting efforts for the regional aquifer assessment with the NWUSP.

\section{wateRuse R Programming Tools}

Using open-source programming software (R), the USGS has developed a package of quality-assurance/quality-control (QA/QC) and visualization tools designed specifically to work with NWUSP aggregate water-use data. This tool enables users, absent of first-hand knowledge of the NWUSP aggregated water-use data, to upload, plot, and visualize the data with multiple spatial, temporal, and categorical specifications. Data can be displayed using simple map plotting functions for multiple years, categories, and areas, such as counties. The $\mathrm{R}$ programming package (wateRuse) is available as an opensource package from the USGS (http://usgs-r.github.io/) and on github (https://github.com/USGS-R/wateRuse).

\section{Irrigation Consumptive Use}

One of the priorities of the Water Census for water-use science and data improvements is to develop scientifically sound and consistent methods for estimating consumptive use on irrigated lands. Irrigation consumptive-use estimates have not been provided nationally as part of NWUSP 5-year compilations since 1995. Irrigation is not the largest category with respect to withdrawals (thermoelectric use accounts for more water withdrawals than irrigation), but more water is used consumptively (evaporated, transpired, or locked up in crop or soil material and otherwise not available for immediate use) 
for irrigation than for all other water-use sectors combined. In 1995, irrigation consumptive use was estimated to be at least 20 times that of thermoelectric consumptive use (Solley and others, 1998). Beginning in 2015, the NWUSP worked collaboratively with other USGS scientists to develop irrigation consumptive-use estimates (expressed as actual evapotranspiration (ETa) and considered equivalent to consumptive use) by using remote-sensing technologies and geospatial applications.

Scientists from the USGS Earth Resources Observation and Science (EROS) Center have provided the NWUSP with 2015 estimates of ETa for the conterminous states plus Hawaii, based on 1-kilometer (0.621-mile) resolution MODIS satellite data analyzed by using the SSEBop model parameterized for operational applications (Senay and others, 2013).

These values represent the spatial and temporal variation of the consumptive use of water across the landscape, depicted as average depth (in inches).

The SSEBop method results in ETa estimates that incorporate the spatial and temporal variation that occurs naturally throughout the growing season. This national coverage of ETa is scientifically defensible, is consistently generated on the basis of remotely sensed data, and can be used as a foundation for the 2015 compilation of irrigation consumptive use. This analysis has shown the importance of the addition of both a detailed GIS layer of irrigated lands throughout the United States and implementation of the increased spatial resolution provided by the use of LANDSAT imagery (30-meter [98.4-ft] resolution) for future water-use compilation efforts.

\section{Water Use Research Funded by Cooperative Matching Funds}

As discussed earlier in the Coordination and Collaboration section of this report, the WAUSP is providing as much as \$2 million per year of Cooperative Matching Funds targeted at water use research projects. The following are two examples of projects with state agencies that are being jointly funded to advance this area of research.

In the State of Georgia, the USGS is working with the Georgia Environmental Protection Division to build on previous work related to the assessment and accounting of 2015 water use information. These assessments involve geospatial analyses, database tools, and comparisons with related published information for the purpose of (1) quantifying water withdrawals, deliveries, and returns by county, hydrologic unit, aquifer, and water planning region; (2) identifying categories of water use or regions of the state where refinements to water use source data are needed for improving accuracy of reported water use information; and (3) identifying sources of information that, if collected at a different spatial or temporal scale, would allow for a more complete and accurate water use accounting for Georgia. USGS will provide alternate technologies or methodologies for collecting or estimating withdrawals, water use deliveries, and returns of water use information with the expectation that improved water use accounting will be incorporated into the State of Georgia's water management strategies. This project is scheduled to end in FY 2018.

The Treasure Valley of southwestern Idaho is the agricultural area that stretches west from Boise, Idaho into Oregon and is commonly referred to as the lower Boise River hydrologic unit. It contains four of the largest cities in Idaho: Boise, Meridian, Nampa, and Caldwell, respectively. The population of the Treasure Valley is about 600,000 , but is projected to grow to 1.6 million by 2065 . The objective of the USGS cooperative water use research study is to work with Idaho Department of Water Resources (IDWR) to develop an updated transient numerical groundwater flow model of Treasure Valley and surrounding areas to be used for water-supply planning and management. As part of the groundwater-flow model development, monthly water use data are collected from water providers in Treasure Valley and entered into the USGS NWIS Site-Specific Water Use Database System (SWUDS). These data are crucial to the accuracy of the groundwater-flow model and is the water-use research component to this project. This project is scheduled to end in 2021.

\section{Improving the Scale of Water-Use Information}

USGS has completed a 6-year, $\$ 5$ million project to develop a site-specific database of public-water-supply systems and their groundwater and surface-water sources. This project is the first part of the effort to refine the scale of available water-use information from county and State totals to site-specific data, which can be used to analyze water use for watersheds at multiple scales.

The public-supply database effort was coordinated with the EPA and utilized a 2010 end-of-year dataset from the EPA Safe Drinking Water Information System national database (SDWIS/Fed), which contains public water system information as reported by states to the EPA (https://www.epa.gov/ ground-water-and-drinking-water/safe-drinking-water-information-system-sdwis-federal-reporting). SDWIS/Fed includes system and water-source information, but does not have water withdrawals. Under the agreement with the EPA, USGS treats all public-water-source information obtained from SDWIS/ Fed as proprietary.

The information on systems and water sources from SDWIS/Fed was first integrated into an interim database called Public Supply Database (PSDB), which also contains a 2010 extract of public supply sources from the USGS NWIS. The structure and development of PSDB is documented in Price and Maupin (2014). PSDB was then used to provide system and site information to USGS offices nationwide, where it was more extensively compared to USGS site information and, additionally, to public supply water-use information obtained by USGS from State and local agencies. This work was done to develop the final datasets for the NWIS Site-Specific WaterUse Data System (SWUDS). Water sources and systems not 
already in SWUDS were added, as was information on water movement or conveyances between the sources and systems, and water withdrawal information for the year 2010, the most recent available year at the start of this project. In cases where specific source withdrawals were not available, water volumes are aggregated and stored in SWUDS at the system level.

The SWUDS database provides a circa-2010 archive of the site-specific data underlying the national 5-year report, improving the consistency and quality of those estimates. The site-specific data will be used in water-budget reports to compare available water-use data for this sector to other waterbudget components.

\section{Release of Pre-1985 Data and Statewide Totals}

Beginning in 1985, the underlying data for the 5-year report "Estimated Use of Water in the United States" was developed at the county level (and at the hydrologic cataloging unit level HUC-8 for 1985 to 1995) and stored in the USGS Aggregate Water Use Data System (AWUDS), as part of the NWIS. Prior to the 2010 report, AWUDS was enhanced to support multiple datasets for a given year and state, allowing for one dataset that supports a publication and another that contains the "best available" data—that is, data that incorporate corrections and improved estimates made after publication. Publication datasets are linked to the reports they support, and best available county data are made available through NWISWeb (https://waterdata.usgs.gov/nwis/ wu/) and the Water Census portal (https://cida.usgs.gov/ nwc/\#! waterbudget).

With the additional capability of multiple datasets for counties and watersheds in AWUDS, revisions to this important set of water-use estimates can be tracked and documented. However, the data for the reports from 1950 to 1980 were not available in digital form, and information on revisions to the data since publication was limited. In 2017, AWUDS was enhanced to allow the storage of estimates at the State level for the set of data elements used in the 1960 to 1980 reports (http://water.usgs.gov/watuse/50years.html); data for the 1950 and 1955 reports were beyond the scope of this effort. Published data from the 1960 to 1980 reports were used to develop input data as the publication datasets, and available notes and worksheets on revisions to these data were used to develop "best available" datasets. AWUDS can now (2017) provide a digital data source and a means of tracking revisions for the 1960 to 1980 estimates of water use at the State level, similar to the functionality for 1985 to present county-level estimates.

\section{Water-Use Science Training}

Training needs for the water-use community in the NWUSP have increased with improved computer and database functionality, as well as the need for more accurate water-use data for USGS studies. The NWUSP conducted a project from 2016 through 2017 to develop 1-hour online training modules for all aspects of water-use science. These completed training modules are made available through the USGS Office of Organizational and Employee Development (OED) websites (https://www2.usgs.gov/humancapital/ecd/ecd_telavailcourses. $\mathrm{html})$. The target audience is USGS scientists who collect or use water-use data, but can include scientists from cooperating agencies. The training modules encompass sessions about the concepts of water-use science in USGS, as well as both the aggregated (AWUDS) and site-specific (SWUDS) database systems, and the categories of water use, which include public supply, domestic, industrial, commercial, irrigation, thermoelectric power, hydroelectric power, livestock, mining, aquaculture, and wastewater treatment. The modules provide user interaction with question and answer sessions, and links to glossaries, guidelines, coding forms, and other resources. The training modules are listed below.

- USGS Water Use-Introduction to the 5-Year WaterUse Compilation (DOILearn module USGS-H-17-127)

- USGS Water Use-Water-Use Concepts (DOILearn module USGS-H-17-126)

- USGS Water Use-Public Supply (DOILearn module USGS-H-17-094)

- USGS Water Use-Thermoelectric Power (DOILearn module USGS-H-17-129)

- USGS Water Use-Irrigation (DOILearn module USGS-H-17-128)

\section{Draft Water-Use Science Strategy}

The Water Availability and Use Science Program is producing a science strategy for the NWUSP in 2018. A Draft Science Strategy is planned to be comprehensive of the many aspects of the water-use project. The Draft Science Strategy addresses both new scientific and programmatic directions for the NWUSP, along with the resources necessary to address those efforts both for the WMA headquarters and for the USGS Water Science Centers (WSCs) which support and contribute to the NWUSP. The Draft Science Strategy was guided by a committee, with scientists from many programs across the USGS, along with a representative of Reclamation and of the Western States Water Council.

A Draft Science Strategy was developed around the central theme that water use is an integral component of the hydrologic cycle and, in order to understand that cycle, the USGS must connect water-use information with it-at all spatial scales. This objective means that, in both large and small watersheds and aquifers, the USGS must be able to provide fine-scale water-use information to describe the effects of water use on the hydrology of the watershed or aquifer. The Draft Science Strategy finds that, for most water-use sectors, only site-specific water-use information will fulfill this need.

The USGS has always worked closely with States and their agencies which deal with water use in the compilation 
and analysis of water use information and it will continue this close working relationship. A Draft Science Strategy purports the use of direct surveys of water users, along with the use of statistical models, to provide the needed site-specific wateruse information in areas where it is not readily available from other agencies. The USGS will work closely with its State agency partners to produce the best survey approaches and leverage and advance ongoing State activities to achieve these water-use compilation goals. In order to fully implement these measures, the USGS will have to comply with the requirements of the Paperwork Reduction Act (Pub. L. No. 96-511, 94 Stat. 2812, codified at 44 U.S.C. $\S \S 3501-3521$ ) and will have to invest substantial resources in the development of trained personnel and information technology infrastructure. Further, the Draft Science Strategy proposes relating wateruse information to socioeconomic information, a new area of endeavor for the USGS. This effort is proposed to help expand the National understanding of water use and the factors that influence, or are influenced by, water use.

\section{Environmental Water Science}

The SECURE Water Act, Section 9508 (a) (6) calls for the USGS “...to develop the basis for an improved ability to forecast the availability of water for future economic, energy production, and environmental uses." As further evidence of the interest in environmental uses of water by the U.S. Congress, Section 9508 (b) (1) (D) calls for “.... focus on the scientific integration of any data relating to water use, water flow, or water quality to generate relevant information relating to the impact of human activity on water and ecological resources." Finally, Section 9508 (b) (2) (C) calls for "...developing and applying predictive modeling tools that integrate groundwater, surface water, and ecological systems." Such information will allow water managers and planners to make more effective decisions in the future with regards to the environmental uses of water.

Environmental water science is the study of the quantity, timing, and quality of water flow and storage required to sustain freshwater and estuarine ecosystems and the human well-being and livelihoods that depend on them. Water flow and storage include streamflows as well as variations in water levels in lakes, rivers, streams, springs, wetlands, and aquifers. Environmental water science has advanced greatly over the past two decades, driven largely by a need to improve understanding of the relation between environmental water uses and the environmental flows required to maintain those uses, prevent degradation of freshwater ecosystems, and improve the balance between human and environmental water needs.

In support of environmental water science at the national scale, the USGS is developing innovative tools and web-available resources that provide stakeholders and environmental water science practitioners with the hydrologic and ecological information necessary for comparing natural and altered hydrologic regimes and determining the effects of streamflow alteration and water withdrawals on aquatic ecosystems. To support such comparisons, streamflow-simulation modeling tools for building a national foundation of baseline hydrographs (see Flow at Ungaged Locations) are being developed that will ultimately provide hydrologic data for all ungaged streams in the United States. A baseline hydrograph is a graph that reflects fluctuations in key elements of the natural flow regime (that is, duration, magnitude, timing, frequency, and rate of change in streamflow). The development of a national foundation of baseline hydrographs is an important step in environmental water assessment because it provides a hydrologic reference point with which hydrologic alterations can be considered (for example, comparing a current or modified hydrograph to an unimpaired hydrograph).

\section{Serving Hydrologic and Ecological Information}

Hydrologic and ecological information is being served nationally to stakeholders by means of the Water Census Data Portal (https://cida.usgs.gov/nwc/), which is a data platform and portal where stakeholders can access national estimates of water-budget components for local watersheds, waterwithdrawal data for counties, tools to calculate statistics of daily streamflow records, simulated daily streamflow at ungaged stations, and records of aquatic biology observations. Additionally, the Water Census Data Portal will enable connections to other large data compilations through interactive web services, including data collected by other Federal, State, and Tribal organizations. These Water Census efforts provide stakeholders, water purveyors, scientists, and environmental water practitioners with access to a broad range of data, information, and statistical tools that can be used to support hypothesis-driven experimentation; scientific advancement and innovation; and sustainable water-management practices, water-allocation plans, and water-governance policies.

\section{Calculation of Streamflow Metrics}

Estimates of daily streamflow as well as a suite of ecologically relevant hydrologic measurements are currently integrated with biological observations through the Water Census Data Portal. As part of this national effort, the Water Census has developed software that will calculate a broad suite of ecologically relevant streamflow statistics for any USGS gaging station within the National Water Information System (NWIS; available at https://waterdata.usgs.gov/nwis) by using the Streamflow Statistics Calculator. The Streamflow Statistics Calculator is an online tool that was created to simplify the process of generating hydrologic indicator statistics by using daily streamflow records. Essentially, this tool is an update of the USGS National Hydrologic Assessment Tool (Henriksen and others, 2006) that uses daily streamflow data from NWIS to calculate 183 ecologically relevant streamflow statistics that address multiple aspects of the hydrologic regime. This software tool is also available as a stand-alone open-source 
R package (available at https://github.com/USGS-R/EflowStats) and can be downloaded and used to calculate streamflow statistics on data that reside outside NWIS. Ecologically relevant streamflow statistics that characterize the magnitude, frequency, duration, timing, and predictability of streamflow and flow levels and account for the full range of hydrologic variability are critical for shaping riverine communities and ecosystem processes and for maintaining the biodiversity of aquatic, riparian, and wetland ecosystems. These ecologically relevant streamflow statistics are also important in understanding long-term trends in hydrology and climate and supporting investigations that are concerned with the restoration of flow characteristics that have been lost through flow regulation, water impoundment, or water extraction.

\section{National Classification of Streams}

In addition to the Streamflow Statistics Calculator, a national streamflow classification structure and a set of flexible tools are being developed and will be implemented in the Water Census Data Portal in the future. This classification structure, which will give stakeholders the capability to evaluate a region of interest at the scale necessary for sound management, is offered by the Water Census as one example of a means to classify streams for further environmental water work. The classification structure is designed to a predetermined set of stream classes derived from a subset of existing baseline hydrographs and, alternatively, to provide users with the option of deriving a set of stream classes based on user-specified input. Water managers and practitioners are also encouraged to explore their own classification systems in considering future work. Streamflow classification is one of the primary components of the Ecological Limits of Hydrologic Alteration (ELOHA; Poff and others, 2010), a scientific framework that outlines a multistep environmental water process of building a hydrologic foundation, developing streamflow classification, and constructing flow-ecology and flow-alteration ecological response relations for stream types. Components of the ELOHA framework have been adopted by the Water Census as well as by State and basin agencies that use it to assess hydroecological impairment and as a foundation for prioritization of streamflow restoration.

Streamflow classification is a process of subdividing reference streams by similar hydrologic responses into stream types and is considered to be one of the first steps toward developing environmental water goals. This process requires the aggregation of daily streamflow data, digital watershed boundaries, and datasets characterizing human activities and natural features. The Water Census study by Archfield and others (2013) classified 1,543 streamgages in the conterminous United States (fig. 26) whose catchments are considered to be minimally regulated. Each streamgage used in this study had

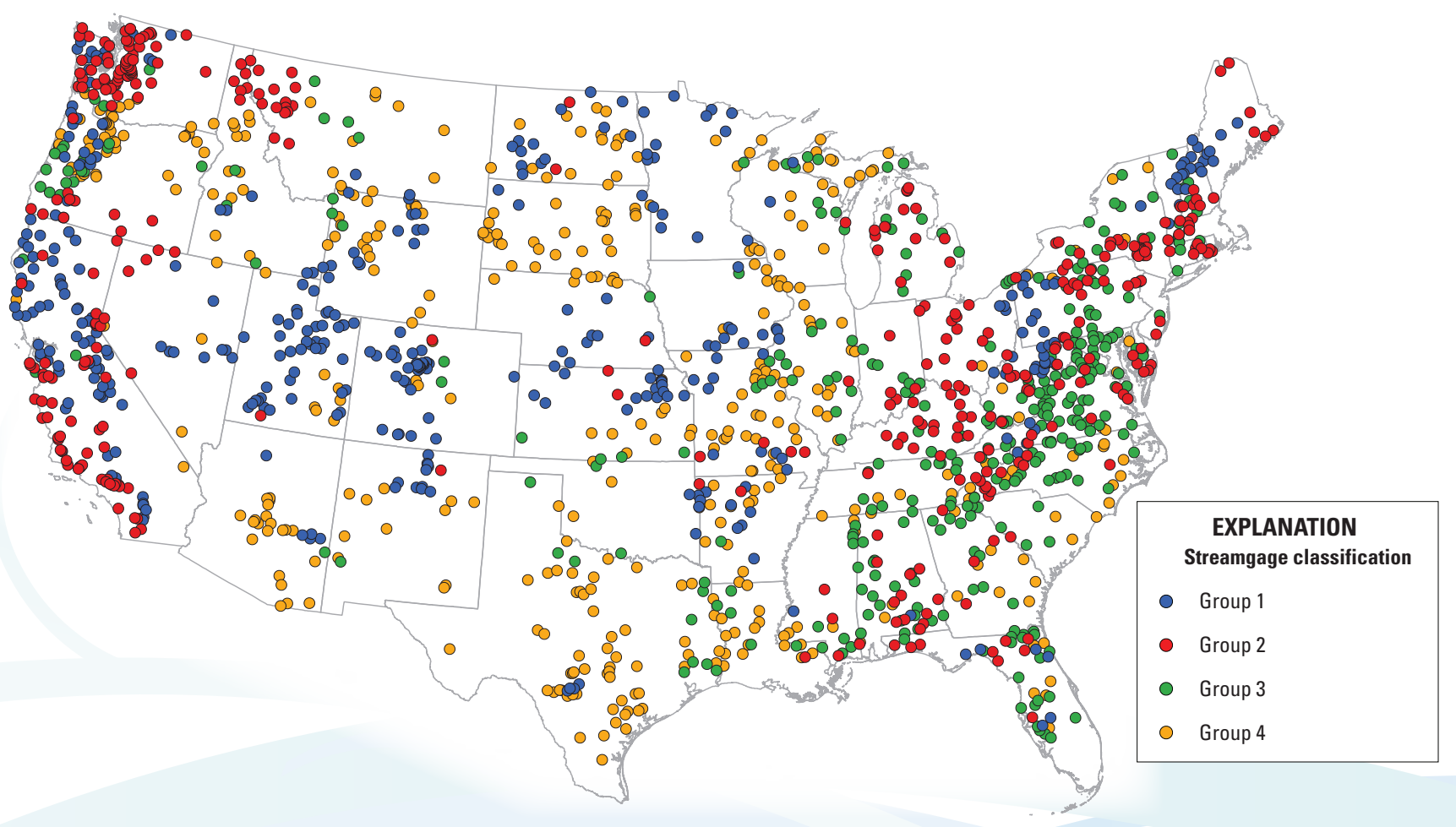

Figure 26. Hydroecological classification of 1,543 U.S. Geological Survey streamgages across the conterminous United States. Four of the eight streamflow classes identified in Archfield and others (2013) are shown. Group 1 (blue) is characterized by the lowest annual variability, fewer outliers, a high correlation with daily streamflow, and a large seasonal signal; group 4 (orange) is characterized by the highest variability, more outliers, a lower correlation with streamflow, and a small seasonal signal. 
a minimum 20-year period of daily streamflow record from 1950 to 2009.

This novel classification approach, the first since Poff (1996), uses seven fundamental properties of daily streamflow to represent the key elements of the natural flow regime. Findings of this study indicate that classification based on the seven fundamental properties of daily streamflow resulted in a high level of stability in streamflow class membership. Additionally, the use of the classification variables allows scientists to communicate results of hydroecological classifications to stakeholders and basin managers effectively and efficiently and provides a standardized classification structure across all regions in the conterminous United States.

\section{Aggregating Ecological Data from Multiple Agency Sources}

One of the fundamentals of environmental water science is the ability to compare hydrologic data with datasets of aquatic biota occurrence and abundance. It is the goal of the Water Census to provide stakeholders with access to the greatest extent of aquatic biological datasets by means of the Data Portal. However, this type of access necessitates an indepth exploration of the comparability of ecological datasets that extend across State, catchment, and regional boundaries. The increasing availability of web-based data-mining sites containing ecological data from multiple agency sources has great potential for furthering understanding of the effects of hydrologic alteration across broad spatial or temporal scales. However, as access to and availability of such data sources become more commonplace, there is a pressing need to understand the effects of the preparation and use of these data on comparability and applicability to environmental water assessments, especially those that may have management or regulatory implications. Inconsistencies in taxonomic data can arise when data from multiple sources are combined. Such inconsistencies can represent operational and management challenges to State agencies and basin stakeholders because they may affect the sensitivity of biotic indices and can reduce their effectiveness for assessing environmental change. Prior to the development of biotic indices, taxonomic data need to be harmonized - that is, resolved to a common taxonomic level across multiple data sources that may use similar collection protocols, but do not necessarily identify organisms to the same taxonomic level or use the same standard organism count.

The Water Census initiated an effort to examine the effects of important taxonomic data processing steps on aquatic invertebrate assemblage structure among nine city, State, interstate, and Federal agency sources within the Delaware River Basin (fig. 27), a Water Census Focus Area. This investigation by Cuffney and Kennen (2017) assesses how differences in data processing can affect numerical criteria for a common set of aquatic invertebrate assemblage metrics and presents how choices made during the data-processing steps can potentially alter the interpretation of relations with known landscape drivers (for example, urban land use, impervious surface cover, and streamflow).

Findings of this innovative Water Census study indicate that great care should be exercised when harmonizing taxa and subsample sizes prior to aggregating data across multiple agency sources. Failure to harmonize taxonomic data can overstate differences among assemblages, reduce the ability to detect environmental change, and introduce methodological discrepancies that can lead to erroneous interpretations of flow-ecology response relations. An important component of all State biomonitoring programs is the translation of an identified change in ecological condition into management goals or actions.

\section{Drought Science}

In 2016, the Congress provided the USGS with funding to improve water data and forecasting for drought. The USGS has worked to create science-based information and tools with the goal to make it easier to monitor, forecast, and provide early warnings for drought. More accurate information about the timing and duration of droughts can enable States, Tribes, counties, and cities to plan more effectively and reduce the effects of drought. The program is also looking to enhance monitoring activities and data-delivery systems to create a stronger link among the ground-based surface-water and groundwater monitoring networks of the USGS, groundwater networks of State agencies, and the soil moisture network of the Natural Resources Conservation Service. The following studies represent work conducted to date (2017) to achieve these objectives.

The first study investigated the behavior of soil moisture during droughts, as simulated in global circulation models (Berg and others, 2017). The study results indicate that analyzing soil-moisture changes on a layer-by-layer basis is important in order to avoid overestimating total soil-water availability. A second study (Dettinger, 2016; Albano and others, 2017) is considering the periodicity of atmospheric rivers and its role in producing humid (rainy) or arid (drought) conditions in the western coastal regions of the Nation. It is postulated that, if researchers can forecast the number of atmospheric rivers that will arrive on the West Coast in coming years, they will have the capability to forecast the majority of drought situations in the region months in advance. The third study focuses on the periodicity of very large storms and medium storms under future conditions and its role in drought occurrence. The research indicated that the future drought regime in California is likely to be one of longer precipitation deficits punctuated by a few very large storms, with the precipitation deficits arising mostly from a decrease in the number of medium-sized storms (Cayan and others, 2016; Dettinger and others, 2016; Harpold and others, 2017). 


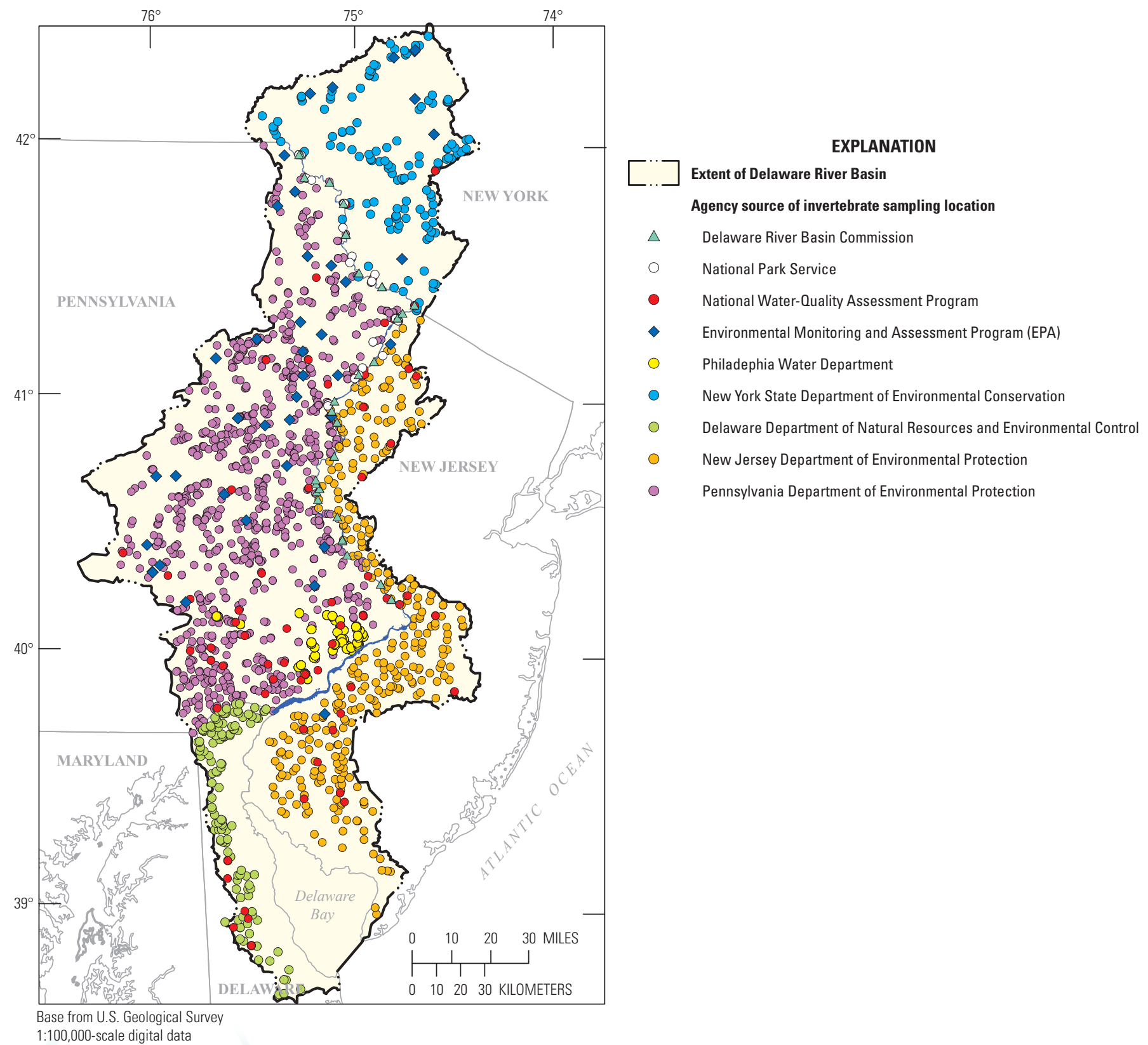

Figure 27. Aquatic invertebrate sampling locations aggregated from nine agency sources in the Delaware River Basin. (Modified from Cuffney and Kennen, 2017) 


\section{Delivering the Data}

To meet the objectives of the Water Census, data from multiple disciplines and sources must be assembled and integrated. Some of these data are obtained from existing sources within the USGS and partner agencies, whereas other data are developed directly as part of the Water Census activities. Many of the "data" developed by the Water Census are derived from models, statistical estimation, and other transformation processes.

A data-management plan has been developed to provide a framework that will guide and document these activities across the entire Water Census effort. The Water Census was one of the first major science efforts in the USGS to formally develop a data-management plan, and the process of data-management planning continues to evolve within the USGS. Data management spans the entire data life cycle to include data acquisition, documentation, processing, analysis, preservation, and delivery. The data-management plan emphasizes adoption of existing international and Federal standards for data elements, processing, preservation, and delivery to serve as unifying and integrating criteria to facilitate interoperability with partners.

The Water Census could not be accomplished without the solid framework of data and science that has been provided by the USGS water programs over the past 125 years. Most of the data used in water-availability analysis is stored in the USGS NWIS database and served to the Nation. The database provides hydrologic data on 1.5 million sites and contains records of surface water, groundwater, water use, and water quality. Additionally, the Water Census draws upon information provided by data portals maintained by other USGS programs, such as the EROS Data Center and the National Water Quality Assessment Water Quality Portal.

\section{Data Integration and Mapping}

Many of the objectives of the Water Census involve delivery of integrated data and information resources. Some of these data, such as precipitation and evapotranspiration (ET), are provided in a form that must be processed to watershed units to be considered in a water budget. Others, like streamflow at ungaged locations, are generated through a combination of data assimilation and modeling and are inherently generated on a per-watershed basis. In both cases, water-budget variables have been processed and cataloged, and are being distributed, on a per-watershed basis.

Precipitation and ET datasets used for the Water Census Data Portal (DP) are available as continuous gridded time series. In the case of ET, each grid cell represents the cumulative monthly ET for a 1-square-kilometer (0.39-square-mile) area. In order to use this ET data in a watershed-based water budget, the gridded time series must be attributed to watershed units by using spatial analysis to intersect grid cells and watershed polygons. For both the SSEBop and Daymet datasets, this attribution was accomplished by using the USGS
Geo Data Portal (GDP) processing system. The GDP's archive (https://cida.usgs.gov/thredds/) serves as the primary host of the SSEBop dataset. The project's processing services (https:// cida.usgs.gov/gdp/) are compatible with the web services provided from the GDP archives as well as those provided by Oak Ridge National Laboratory (Oak Ridge, Tennessee) for Daymet precipitation data.

The spatial analysis performed by the GDP requires a set of watershed polygons. For the Water Census DP, HUC-12 units derived from the Watershed Boundary Dataset were used for this purpose. HUC-12 units are "local-incremental" watershed units, averaging about 35 square miles in size across the Nation. Consequently, upstream HUC-12s must be joined together in order to be representative of an entire watershed. Data QA/QC of the connectivity between HUC$12 \mathrm{~s}$ was completed for the Water Census and published within the Watershed Boundary Dataset. Software that joins the HUC-12 units upstream from a given HUC-12 was developed and is available as an open-source R package at https:// github.com/USGS-R/HUCAgg. Aggregate watershed boundaries and water-budget variables are used to create Water Census DP "accumulated" water-budget data resource pages such as the one at https://cida.usgs.gov/nwc/\#!waterbudget/ achuc/070900020703 for a watershed in Wisconsin. The image in figure 28 depicts all of the area that is contributing flow above the watershed of interest.

For data and model output developed by the USGS, a WATER CENSUS data-management plan was developed that provides requirements and guidance for data management. It is used as a program-wide policy to ensure consistency in planning, execution, and delivery of data from all WATER CENSUS activities. By using the plan, projects have clear guidelines for the data and metadata that will need to be delivered and the repository that will be used if no enterprise repository, such as the USGS's NWIS, is available for the project's deliverables.

The USGS ScienceBase repository (https://www. sciencebase.gov/catalog/item/5151f07ee4b0f0b3d011a817) is being used as a catalog and data store to track projects and their deliverables including publications, models, and datasets. Many of the model and data outcomes of focus area and topical studies are available directly from ScienceBase, whereas reports and data stored elsewhere are available through links cataloged in ScienceBase. As mentioned above, SSEBop estimates of evapotranspiration have been deposited in the GDP model data archive, and water-use data are housed in NWIS.

\section{The National Data Platform}

As they are completed, WATER CENSUS data resources are published through a single portal, the DP (https://cida. usgs.gov/nwc/) that helps users discover information for 8and 12-digit HUC watersheds. The DP provides a map view of HUCs, allowing users to zoom to their area of interest and select one of the Water Census watershed units. Once the 


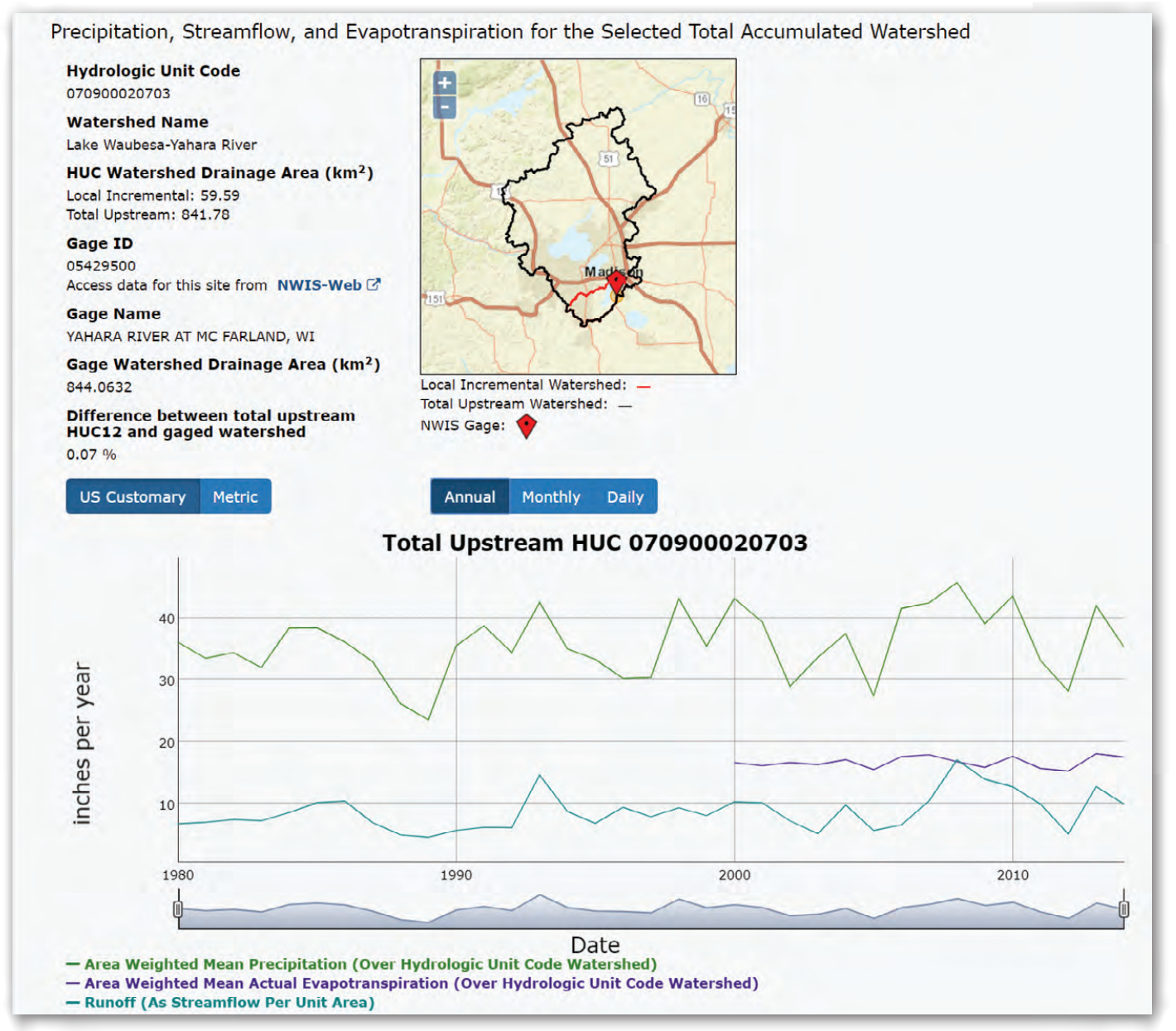

Figure 28. An accumulated water budget for a watershed in Wisconsin showing precipitation, streamflow, and evapotranspiration. (From U.S. Geological Survey, 2017f)

appropriate watershed has been selected, a user can explore the dominant water-budget components of the watershed in which they have an interest.

In the first 5 years of the WATER CENSUS, DP development has included building infrastructure to catalog and display completed nationally consistent water-budget data for any HUC-12 watershed in the country. In the next 5 years, this infrastructure will be leveraged to provide a complete, closed water budget as discussed previously in this report. As of 2017, the DP contains precipitation data from Daymet and ET data from SSEBop for every watershed in the lower 48 states, and area-aggregated water-use estimates for counties from the AWUDS database. Daymet data are available starting in 1980, SSEBop data are available starting in 2000, and AWUDS data are available starting in 1985. For watersheds that have an NWIS streamgage near their outlet and for watersheds in part of the southeastern United States, where modeling has been completed, runoff data (represented as streamflow per unit area) are also available. Streamflow data for the rest of the country will be added in 2018. In the next 5 years, as progress is made on modeling a complete, closed water budget, it is expected that other terms, such as storage, snow water equivalent, and site-specific water use, will be included.

The DP also includes pilot functionality to discover aquatic-biology data and utilities to calculate streamflow statistics for environmental water evaluation. As the DP progresses, this functionality will be maintained but may be combined into other data systems better suited to satisfying the needs of environmental water studies. A view of the resources in the ScienceBase project data inventory is also included in the DP. It is expected that this functionality will be migrated to the main WATER CENSUS web presence as the USGS webpage infrastructure is updated in the coming years.

In order to facilitate use of the portal and its data resources, a set of educational materials targeted at a college hydro-informatics classroom was developed. The materials, which are available at https://github.com/NWCEd/NWCEd, provide a set of classroom activities that guide students through the use of the portal and its data as well as introduce them to basic hydro-informatics scripting concepts. These materials are available publicly at https://github.com/USGS-R/ NWCEd and are documented in Nelson (2017). 
Each water-budget data resource can be accessed from a unique URL of the form:

https://cida.usgs.gov/nwc/\#!waterbudget/achuc/070900020703,

where

"https://cida.usgs.gov/nwc/\#!waterbudget/" is the portal entry to all

water-budget data resources and

“achuc/070900020703" specifies the total accumulated upstream watershed view of hydrologic unit 070900020703.

Building the system by using these referenceable URLs allows the waterbudget data resources to be included in other information products and will aid in future efforts to expose the system to search engines.

\section{Planning for the Future}

Progress toward a Water Census has been made by initiating new work and by integrating information from a number of programs and ongoing national-scale efforts, such as the USGS Groundwater and Streamflow Information Program and the USGS Regional Groundwater Evaluations. USGS efforts have also built upon the legacy provided by long-term monitoring and assessment programs funded under the previous USGS Cooperative Water Program and the National Streamflow Information Program. Over the next 5 years, progress will continue with the existing efforts and expand as funding allows. In addition to completing the ongoing work described in this report, priorities for future work are described below.

\section{Future Geographic Focus Area Studies}

The Water Census will complete the three ongoing FASs and will initiate new FASs in the future. The three ongoing studies are planned for completion by 2019 and the Water Census will initiate a process prior to their completion to select new locations for FASs. As stated earlier, the Water Census has learned a great deal from the six FASs that are either completed or ongoing. They (1) contribute to ongoing assessments of water availability in large watersheds with potential water-use conflicts, (2) provide high-resolution water-use databases that can be used for a multitude of purposes, (3) provide opportunities to test and improve approaches to water-availability assessment that can be transferred to other areas, and (4) inform and "ground truth" the Water Census with local information. The Water Census FASs also fulfill USGS reporting on two of the primary assessments that the U.S. Congress requested of the USGS in the SECURE Water Act: where are the significant water-use conflicts or shortages that have occurred, or are occurring, and what are the factors that have caused, or are causing, the conflict or shortage?

The Water Census has previously used a two-stage process for soliciting and selecting candidates for new FASs. The first stage involves soliciting USGS WSCs to nominate candidate river basins, through an efficient preproposal process, for the future studies. The second stage involves full proposals of candidates from the earlier stage. All proposals are reviewed by a panel of experts from across the USGS and a representative of the Bureau of Reclamation. The final candidate FASs are selected for project funding over a 3-year period.

Within the effort scoped for FASs, the emphasis will remain on fulfilling the water-use data needs at the HUC-8 level. Continuing to compile water-use data for the major categories (as reported since 2010), and potentially backfilling in other categories of use, such as waste-water return flows, would benefit the NWUSP as well as other Water Census project objectives, such as closing the water budget. Collecting as much site-specific data as possible for categories such as public supply and thermoelectric water withdrawals will be beneficial. These data will be stored in the appropriate USGS NWIS databases, either aggregated or site-specific. These data will help to improve the knowledge about water budgets and assess trends in water use.

\section{Modeling Approach}

Over the next 5 years, the Water Census will place a considerable effort on providing current and historical wateravailability information on a daily time step and at the scale of HUC-12 subbasins. For context, HUC-12 subbasins average approximately 35 square miles in area and there are approximately 88,500 of them in the conterminous United States. 
The Water Census strives to present a daily water budget for each of these subbasins within the conterminous United States within the next 5 years. The primary building blocks of the water budget are precipitation, streamflow, ET, water use, and change in storage. Today, the Water Census, through the WATER CENSUS DP, presents a continuous coverage for the conterminous United States of precipitation at a daily time step and ET at a monthly time step. Streamflow is presented at a daily time step only for the southeastern United States, and water use is presented only on a county scale and at 5-year time intervals for the conterminous United States. There is much work to be accomplished in the next 5 years.

The first set of priorities will be to provide daily streamflow estimates for the remainder of the conterminous United States and to increase estimation of ET from a monthly time step to a daily time step. These tasks will be accomplished through the application of a watershed model, which is calibrated to physical measurements of water-budget components at various locations across the United States and simulates those components where measurements do not exist. The watershed model will generate the daily estimates of streamflow and ET at the scale of HUC-12 subbasins and the estimates will be provided to the public through the WATER CENSUS DP at https://cida.usgs.gov/nwc/. The ET estimates from the model will incorporate information from ET estimation using remote-sensing data from LandSAT.

As stated previously in this report, water budgets provide the foundation for sound water-availability analysis. When all of the water-budget components for a watershed have been estimated, hydrologists work through a process to "close" the water budget. This process involves balancing all components of the water budget so that the sum of the supply terms equals the sum of the demand terms, taking into account changes in storage. During the next 5 years, the Water Census will use a selected modeling application to close the water budget for HUC-12 watersheds throughout the conterminous United States at a daily time step.

In the area of environmental water science, ongoing national classification work by the Water Census is leveraging the findings of the Archfield and others (2013) study to develop statistical models that will be used over the next 5 years to assign all ungaged rivers in the conterminous United States to one of the published stream classes on the basis of measured basin and climate characteristics within an established range of uncertainty. Once completed, this follow-up effort will provide a broad-based classification structure that can be overlain onto a national mapping framework, such as NHDPlus, and used as a basis for understanding the full scope of stream classes across the United States. Additionally, this study is evaluating the degree of model misclassification (that is, the level of uncertainty in stream-class assignment), which will provide stakeholders with the information necessary to make informed decisions about management actions that may affect all streams of a given stream class.

The science of environmental water continues to progress, in part as a result of frameworks such as ELOHA, which have provided a strong scientific foundation for stakeholders and environmental water practitioners that support a better understanding of the interdependencies between streamflow and ecological response. Future Water Census efforts will place a strong emphasis on the development of newer, more dynamic statistical and process modeling techniques capable of integrating components of the water cycle and accounting for ecosystem response. These dynamic models will leverage the availability of synthetic hydrographs developed by using simulation modeling and the broader access to biological data through web sources to support an improved understanding of the relations between streamflow change and ecological response. This type of approach is strongly needed and represents the fundamental underpinnings of environmental water science and management in the future.

\section{Future Databases Needed}

In the next 5 years, the Water Census will create a database of interbasin transfers of water in the United States. Interbasin transfers are the movement of water from one subregion (HUC-4) to another through manmade or artificial conduits (tunnels, canals, pipes) in most cases, but also possibly through natural conduits (rivers or reservoir connections). In all of these cases, the transfer of water is under human management and control. Interbasin transfers are necessary when water is moved to meet demands in regions outside the source watershed. Because it is difficult, if not impossible, to account for all of the individual categories and quantities of uses of the water in the receiving subregion, this effort will focus on accounting for the total quantities of water that are transferred, to the smallest temporal scale (seasonal, monthly) possible within the context of accuracy limitations. The USGS inventoried interbasin water transfers at the HUC-4 scale for calendar years 1973 to 1982 in the western states (Petsch, 1985) and the eastern states (Mooty and Jeffcoat, 1986). At the time of these reports, 256 interbasin water transfers were inventoried. Water transfers can have a substantial effect on the hydrology of and water availability in both the exporting and importing basins, and it is of great interest to the NWUSP to inventory and assess the characteristics of interbasin transfers. Transfers are also crucial to the understanding of water budgets in both the exporting and receiving river basins.

The NWUSP will begin regular reporting of interbasin transfers of water at the HUC-4 scale. Transfers of water that exceed 100,000 gallons per day averaged over a calendar month will be counted. This rate will be known as the volumetric threshold for interbasin transfers.

The NWUSP will identify the names and locations of all conveyances that transfer water in excess of the volumetric threshold between two HUC-4 basins on an annual basis. The location data will include the latitude and longitude of the point of origin of the conveyance and the initial point of delivery in the receiving HUC-4 basin. Storing the locations of these diversion sites as point locations in NWIS would enable the water-transfer data to be provided to other WAUSP project 
activities, such as mapping water depletions for use in waterbudget analyses at the HUC-4 basin scale

This work will be a multiagency effort, with collaboration and cooperation among the USGS, U.S. Army Corp of Engineers, Bureau of Reclamation, and State agencies that are responsible for the management and operation of interbasin transfers. This effort will begin with forming a multiagency committee to identify other agencies and organizations that have purview over water transfers and the operation of the infrastructure that enables the transfers. As part of an inventory, an informational survey will be shared with the committee to update and improve the listing of interbasin transfers, including assessing locational information and identifying geospatial nomenclature.

Through these ongoing and planned future activities, the USGS will add to the science of water availability and incrementally work toward the goal that Congress articulated in the SECURE Water Act - an ongoing national assessment of water availability and use.

\section{References Cited}

Ahlfeld, D.P., and Barlow, P.M., 2013, Use of multi-node wells in the Groundwater-Management Process of MODFLOW-2005 (GWM-2005): U.S. Geological Survey Techniques and Methods, book 6, chap. A47, 26 p. [Also available at $\mathrm{http}: / /$ pubs.usgs.gov/tm/06/a47/.]

Albano, C.M., Dettinger, Michael, and Soulard, C.E., 2017, Influence of atmospheric rivers on vegetation productivity and fire patterns in the southwestern U.S.: Journal of Geophysical Research-Biogeosciences, p. 308-323. [Also available at https://doi.org/10.1002/2016JG003608.]

Alley, W.M., Evenson, E.J., Barber, N.L., Bruce, B.W., Dennehy, K.F., Freeman, M.C., Freeman, W.O., Fischer, J.M., Hughes, W.B., Kennen, J.G., Kiang, J.E., Maloney, K.O., Musgrove, MaryLynn, Ralston, Barbara, Tessler, Steven, and Verdin, J.P., 2013, Progress toward establishing a national assessment of water availability and use: U.S. Geological Survey Circular 1384, 34 p. [Also available at https://pubs.usgs.gov/circ/1384.]

Anderson, M.P., Woessner, W.W., and Hunt, R.J., 2015, Applied groundwater modeling - Simulation of flow and advective transport ( $2 \mathrm{~d}$ ed.): Amsterdam, Elsevier, $564 \mathrm{p}$. [Also available at https://www.elsevier.com/books/appliedgroundwater-modeling/anderson/978-0-08-091638-5.]

Archfield, S.A., Kennen, J.G., Carlisle, D.M, and Wolock, D.M., 2013, An objective and parsimonious approach for classifying natural flow regimes at a continental scale: River Research and Applications, v. 30, no. 9, p. 1166-1183. [Also available at https://doi.org/10.1002/rra.2710.]
Archfield, S.A., Vogel, R.M., Steeves, P.A., Brandt, S.L., Weiskel, P.K., and Garabedian, S.P., 2010, The Massachusetts Sustainable-Yield Estimator-A decision-support tool to assess water availability at ungaged stream locations in Massachusetts: U.S. Geological Survey Scientific Investigations Report 2009-5227, 41 p. plus CD-ROM. [Also available at https://pubs.usgs.gov/sir/2009/5227/.]

Arnold, J.G., and Fohrer, Nicola, 2005, SWAT2000 - Current capabilities and research opportunities in applied watershed modelling: Hydrological Processes, v. 19 no. 3, p. 563-572. [Also available at https://doi.org/10.1002/hyp.5611.]

Bakker, Mark, Post, V.E.A., Langevin, C.D., Hughes, J.D., White, J.T., Starn, J.J., and Fienen, M.N., 2016, Scripting MODFLOW model development using Python and FloPy: Groundwater, v. 54, no. 5, p. 733-739. [Also available at https://doi.org/10.1111/gwat.12413.]

Barlow, P.M., Cunningham, W.L., Zhai, Tong, and Gray, Mark, 2015, U.S. Geological Survey Groundwater Toolbox, a graphical and mapping interface for analysis of hydrologic data (ver. 1.0) - User guide for estimation of base flow, runoff, and groundwater recharge from streamflow data: U.S. Geological Survey Techniques and Methods, book 3, chap. B10, 27 p. [Also available at https://doi.org/10.3133/ tm3B10.]

Bedekar, Vivek, Morway, E.D., Langevin, C.D., and Tonkin, M.J., 2016, MT3D-USGS (ver. 1)-A U.S. Geological Survey release of MT3DMS updated with new and expanded transport capabilities for use with MODFLOW: U.S. Geological Survey Techniques and Methods, book 6, chap. A53, 69 p. [Also available at https://doi.org/10.3133/tm6A53.]

Berg, Alexis, Sheffield, Justin, and Milly, P.C.D., 2017, Divergent surface and total soil moisture projections under global warming: Geophysical Research Letters, v. 44, no. 1, p. 236-244. [Also available at https://doi. org/10.1002/2016GL071921.]

Bock, A.R., Hay, L.E., McCabe, G.J., Markstrom, S.L., and Atkinson, R.D., 2016, Parameter regionalization of a monthly water balance model for the conterminous United States: Hydrology and Earth System Sciences, v. 20, p. 2861-2876. [Also available at https://doi.org/10.5194/hess20-2861-2016.]

Bourgin, Francois, Andréassian, Vazken, Perrin, Charles, and Oudin, Ludovic, 2015, Transferring global uncertainty estimates from gauged to ungauged catchments, Hydrology and Earth System Sciences, v. 19, no. 5, p. 2535-2546. [Also available at https://doi.org/10.5194/hess-19-2535-2015.] 
Cayan, D.R., Dettinger, M.D., Pierce, David, Das, Tapash, Knowles, Noah, Ralph, F.M., and Sumargo, Edwin, 2016, Natural variability, anthropogenic climate change, and impacts on water availability and flood extremes in the western United States, in Miller, K.A., Hamlet, A.F., Kenney, D.S., and Redmond, K.T., eds., Water policy and planning in a variable and changing climate: Boca Raton, Florida, CRC Press, chap. 2, p. 17-42. [Also available at http://tenaya.ucsd.edu/ dettinge/Cayan_Miller2016chap. pdf.]

Chen, Mingshi, Senay, G.B., Singh, R.K., and Verdin, J.P., 2016, Uncertainty analysis of the Operational Simplified Surface Energy Balance (SSEBop) model at multiple flux tower sites: Journal of Hydrology, v. 536, p. 384-399. [Also available at https://doi.org/10.1016/j.jhydrol.2016.02.026.]

Clow, D.W., 2010, Changes in the timing of snowmelt and streamflow in Colorado-A response to recent warming: Journal of Climate, v. 23, no. 9, p. 2293-2306. [Also available at https://doi.org/10.1175/2009jcli2951.1.]

Clow, D.W., Nanus, Leora, Verdin, K.L., and Schmidt, Jeffrey, 2012, Evaluation of SNODAS snow depth and snow water equivalent estimates for the Colorado Rocky Mountains, USA: Hydrological Processes, v. 26, no. 17, p. 2583-2591. [Also available at https://doi.org/10.1002/hyp.9385.]

Clow, D.W., Williams, M.W., and Schuster, P.F., 2016, Increasing aeolian dust deposition to snowpacks in the Rocky Mountains inferred from snowpack, wet deposition, and aerosol chemistry: Atmospheric Environment, v. 146, p. 183-194. [Also available at https://doi.org/10.1016/j. atmosenv.2016.06.076.]

Conrads, P.A., Roehl, E.A., Jr., Daamen, R.C., and Cook, J.B., 2013, Simulation of salinity intrusion along the Georgia and South Carolina coasts using climate-change scenarios: U.S. Geological Survey Scientific Investigations Report 2013-5036, 92 p., 5 app. [Also available at http://pubs.usgs. gov/sir/2013/5036/.]

Cuffney, T.F., and Kennen, J.G., 2017, Potential pitfalls of aggregating aquatic invertebrate data from multiple agency sources-Implications for detecting aquatic assemblage change across alteration gradients: Freshwater Biology, v. 00 (Special Issue), p. 1-14. [Also available at https://doi. org/10.1111/fwb.13031.]

Dennehy, K.F., Reilly, T.E., and Cunningham, W.L., 2015, Groundwater availability in the United States-The value of quantitative regional assessments: Hydrogeology Journal, v. 23, no. 8, p. 1629-1632. [Also available at https://doi. org/10.1007/s10040-015-1307-5.]
Dettinger, Michael, 2016, Historical and future relations between large storms and droughts in California: San Francisco Estuary and Watershed Science, v. 14, no. 2, p. 1-21. [Also available at https://doi.org/10.15447/ sfews.2016v14iss2art1.]

Dettinger, Michael, Anderson, Jamie, Anderson, M.L., Brown, L.R., Cayan, Daniel, and Maurer, E.P., 2016, Climate change and the Delta: San Francisco Estuary and Watershed Science, v. 14, no. 3, 26 p. [Also available at https://doi. org/10.15447/sfews.2016v14iss3art5.]

Diehl, T.H., and Harris, M.A., 2014, Withdrawal and consumption of water by thermoelectric power plants in the United States, 2010: U.S. Geological Survey Scientific Investigations Report 2014-5184, 28 p. [Also available at https://doi.org/10.3133/sir20145184.]

Diehl, T.H., Harris, M.A., Murphy, J.C., Hutson, S.S., and Ladd, D.E., 2013, Methods for estimating water consumption for thermoelectric power plants in the United States: U.S. Geological Survey Scientific Investigations Report 2013-5188, 78 p. [Also available at https://doi.org/10.3133/ sir20135188.]

Dieter, C.A., Linsey, K.S., Caldwell, R.R., Harris, M.A., Ivahnenko, T.I., Lovelace, J.K., Maupin, M.A., and Barber, N.L., 2017, Estimated use of water in the United States county-level data for 2015: U.S. Geological Survey data release, accessed February 1, 2018, at https://doi. org/10.5066/F7TB15V5.

Dieter, C.A., and Maupin, M.A., 2017, Public supply and domestic water use in the United States, 2015: U.S. Geological Survey Open-File Report 2017-1131, 6 p.. [Also available at https://doi.org/10.3133/ofr20171131.]

Driscoll, J.M., Markstrom, S.L., Regan, R.S., Hay, L.E., and Viger, R.J., 2017, National Hydrologic Model Parameter Database-2017-05-08 download: U.S. Geological Survey data release, accessed February 1, 2018, at https://doi. org/10.5066/F7NS0SCW.

Dudley, R.W., Hodgkins, G.A., McHale, M.R., Kolian, M.J., and Renard, Benjamin, 2016, Winter-spring streamflow volume and timing data for 75 Hydroclimatic Data Network-2009 basins in the conterminous United States 1920-2014: U.S. Geological Survey data release, accessed September 29, 2017, at https://doi.org/10.5066/F7R78CBX.

Falcone, James, 2011, GAGES-II-Geospatial attributes of gages for evaluating streamflow: U.S. Geological Survey metadata, accessed July 27, 2017, at https://water.usgs.gov/ GIS/metadata/usgswrd/XML/gagesII_Sept2011.xml. 
Farmer, W.H., Archfield, S.A., Over, T.M., Hay, L.E., LaFontaine, J.H., and Kiang, J.E., 2014, A comparison of methods to predict historical daily streamflow time series in the southeastern United States: U.S. Geological Survey Scientific Investigations Report 2014-5231, 34 p. [Also available at https://doi.org/10.3133/sir20145231.]

Farmer, W.H., Knight, R.R., Eash, D.A., Hutchinson, K.J., Linhart, S.M., Christiansen, D.E., Archfield, S.A., Over, T.M., and Kiang, J.E., 2015, Evaluation of statistical and rainfall-runoff models for predicting historical daily streamflow time series in the Des Moines and Iowa River watersheds: U.S. Geological Survey Scientific Investigations Report 2015-5089, 34 p.. [Also available at https:// doi.org/10.3133/sir20155089.]

Farmer, W.H., and Levin, Sara, 2017, Characterizing uncertainty in daily streamflow estimates at ungauged locations for the Massachusetts Sustainable Yield Estimator: Journal of the American Water Resources Association, v. 54, no. 1, p, 198-210. [Also available at https://doi.org/10.1111/17521688.12603.]

Farmer, W.H., and Vogel, R.M., 2016, On the deterministic and stochastic use of hydrologic models: Water Resources Research, v. 52, no. 7, p. 5619-5633. [Also available at https://doi.org/10.1002/2016WR019129.]

Feth, J.H.F., 1965, Preliminary map of the conterminous United States showing depth to and quality of shallowest ground water containing more than 1,000 parts per million dissolved solids: U.S. Geological Survey Hydrologic Atlas 199, 31 p., 2 pl., 1:3,000,000. [Also available at https:// pubs.er.usgs.gov/publication/ha199.]

Fitts, C.R., 2013, Groundwater science (2d ed.): Amsterdam, Academic Press, 672 p. [Also available at https://www. sciencedirect.com/science/book/9780123847058.]

Freeman, M.C., Buell, G.R., Hay, L.E., Hughes, W.B., Jacobson, R.B., Jones, J.W., Jones, S.A., LaFontaine, J.H., Odom, K.R., Peterson, J.T., Riley, J.W., Schindler, J.S., Shea, C.P., and Weaver, J.D., 2013, Linking river management to species conservation using dynamic landscape-scale models: River Research and Applications, v. 29, no. 7, p. 906-918. [Also available at https://doi.org/10.1002/rra.2575.]

Gordon, D.W., Peck, M.F., and Painter, J.A., 2012, Hydrologic and water-quality conditions in the lower ApalachicolaChattahoochee-Flint and parts of the Aucilla-SuwaneeOchlockonee River basins in Georgia and adjacent parts of Florida and Alabama during drought conditions, July 2011: U.S. Geological Survey Scientific Investigations Report 2012-5179, 69 p., 1 sheet. [Also available at http://pubs. usgs.gov/sir/2012/5179/.]
Harpold, A.A., Dettinger, Michael, and Rajagopal, Seshadri, 2017, Defining snow drought and why it matters: EOS, Earth and Space Science News, v. 98, no. 5, p. 15-17. [Also available at https://eos.org/wp-content/uploads/2017/04/ May-17_magazine.pdf?x35494.]

Harris, M.A., and Diehl, T.H., 2017a, A comparison of three Federal datasets for thermoelectric water withdrawals in the United States for 2010: Journal of the American Water Resources Association, v. 53, no. 5, p. 1062-1080. [Also available at https://doi.org/10.1111/1752-1688.12551.]

Harris, M.A., and Diehl, T.H., 2017b, Thermoelectric power plant water withdrawals and associated attributes for three Federal datasets in the United States, 2010: U.S. Geological Survey data release, accessed February 1, 2018, at https:// doi.org/10.5066/F7HX19VW.

Healy, R.W., Winter, T.C., LaBaugh, J.W., and Franke, O.L., 2007, Water budgets - Foundations for effective waterresources and environmental management: U.S. Geological Survey Circular 1308, 90 p. [Also available at https://pubs. usgs.gov/circ/2007/1308/.]

Henriksen, J.A, Heasley, John, Kennen, J.G., and Nieswand, Steven, 2006, Users' manual for the Hydroecological Integrity Assessment Process software (including the New Jersey Assessment Tools): U.S. Geological Survey OpenFile Report 2006-1093, 71 p. [Also available at https:// www.fort.usgs.gov/sites/default/files/products/publications/21598/21598.pdf.]

Hirsch, R.M., and Archfield, S.A., 2015, Flood trends-Not higher but more often: Nature Climate Change, v. 5, no. 3, p. 198-199. [Also available at https://doi.org/10.1038/nclimate2551.]

Hirsch, R.M., and Ryberg, K.R., 2012, Has the magnitude of floods across the USA changed with global CO2 levels?: Hydrological Sciences Journal, v. 57 no. 1, p. 1-9. [Also available at http://dx.doi.org/10.1080/02626667.2011.6218 95.]

Hodgkins, G.A., and Dudley, R.W., 2006, Changes in the timing of winter-spring streamflows in eastern North America, 1913-2002: Geophysical Research Letters, v. 33, no. 6, 5 p. [Also available at https://doi.org/10.1029/2005GL025593.]

Hodgkins, G.A., Dudley, R.W., Nielsen, M.G., Renard, Benjamin, and Qi, S.L., 2017a, Groundwater-level trends in the U.S. glacial aquifer system, 1965-2013: Journal of Hydrology, v. 553, p. 289-303. [Also available at https:// doi.org/10.1016/j.jhydrol.2017.07.055.] 
Hodgkins, G.A., Whitfield, P.H., Burn, D.H., Hannaford, Jamie, Renard, Benjamin, Stahl, Kerstin, Fleig, A.K., Madsen, Henrik, Mediero, Luis, Korhonen, Johanna, Murphy, Conor, and Wilson, Donna, 2017b, Climatedriven variability in the occurrence of major floods across North America and Europe: Journal of Hydrology, v. 552, p. 704-717. [Also available at https://doi.org/10.1016/j. jhydrol.2017.07.027.]

Hughes, J.D., Langevin, C.D., and Banta, E.R., 2017, Documentation for the MODFLOW 6 framework: U.S. Geological Survey Techniques and Methods, book 6, chap. A57, 36 p. [Also available at https://doi.org/10.3133/tm6A57.]

Hutson, S.S., Linsey, K.S., Ludlow, R.A., Reyes, Betzaida, and Shourds, J.L., 2016a, Estimated use of water by subbasin (HUC8) and subwatershed (HUC12) in the Delaware River Basin, 2010: U.S. Geological Survey data release, accessed September 29, 2017, at http://dx.doi.org/10.5066/ F7TM787C

Hutson, S.S., Linsey, K.S., Ludlow, R.A., Reyes, Betzaida, and Shourds, J.L., 2016b, Estimated use of water in the Delaware River Basin in Delaware, New Jersey, New York, and Pennsylvania, 2010: U.S. Geological Survey Scientific Investigations Report 2015-5142, 76 p. [Also available at https://doi.org/10.3133/sir20155142.]

Johnston, R.H., 1999, Hydrologic budgets of regional aquifer systems of the United States for predevelopment and development conditions: U.S. Geological Survey Professional Paper 1425, 34 p. [Also available at https://pubs.er.usgs. gov/publication/pp1425.]

Jones, L.E., Painter, Jaime, LaFontaine, Jacob, Sepulveda, Nicasio, and Sifuentes, D.F., 2017, Groundwater-flow budget for the lower Apalachicola-Chattahoochee-Flint River Basin in southwestern Georgia and parts of Florida and Alabama, 2008-12: U.S. Geological Survey Scientific Investigations Report 2017-5141, 76 p. [Also available at https://doi.org/10.3133/sir20175141.]

Kasmarek, M.C., and Johnson, M.R., 2013, Groundwater withdrawals 1976, 1990, and 2000-10 and land-surfaceelevation changes 2000-10 in Harris, Galveston, Fort Bend, Montgomery, and Brazoria Counties, Texas: U.S. Geological Survey Scientific Investigations Report 2013-5034, 17 p. [Also available at https://pubs.usgs.gov/ $\operatorname{sir} / 2013 / 5034 /$.

Kiang, J.E., Mason, R.R., Jr., and Cohn, T.A., 2016, A survey of the uncertainty in stage-discharge rating curves and streamflow records in the United States, in Constantinescu, George, Garcia, Marcelo, and Hanes, Dan, eds., River Flow 2016-Proceedings of the International Conference on Fluvial Hydraulics, St. Louis, USA, July 11-14, 2016: Leiden, The Netherlands, CRC Press, p. 724-728. [Also available at https://doi.org/10.1201/9781315644479-114.]
Kiang, J.E., Stewart, D.W., Archfield, S.A., Osborne, E.B., and Eng, Ken, 2013, A national streamflow network gap analysis: U.S. Geological Survey Scientific Investigations Report 2013-5013, 79 p. plus appendix. [Also available at http:// pubs.usgs.gov/sir/2013/5013/.]

LaFontaine, J.H., Jones, L.E., and Painter, J.A., 2017, Simulations of hydrologic response in the Apalachicola-Chattahoochee-Flint River Basin, Southeastern United States: U.S. Geological Survey Scientific Investigations Report 20175133, 112 p. [Also available at https://doi.org/10.3133/ sir20175133.]

Langevin, C.D., Hughes, J.D., Banta, E.R., Niswonger, R.G., Panday, Sorab, and Provost, A.M., 2017, Documentation for the MODFLOW 6 Groundwater Flow Model: U.S. Geological Survey Techniques and Methods, book 6, chap. A55, variously paged. [Also available at https://doi.org/10.3133/ tm6A55.]

Langevin, C.D., Thorne, D.T., Jr., Dausman, A.M., Sukop, M.C., and Guo, Weixing, 2008, SEAWAT (ver. 4)-A computer program for simulation of multi-species solute and heat transport: U.S. Geological Survey Techniques and Methods, book 6, chap. A22, 39 p. [Also available at https:// pubs.usgs.gov/tm/tm6a22/.]

Lawrence, S.J., 2016, Water use in the Apalachicola-Chattahoochee-Flint River Basin, Alabama, Florida, and Georgia, 2010, and water-use trends, 1985-2010: U.S. Geological Survey Scientific Investigations Report 2016-5007, 72 p. [Also available at https://doi.org/10.3133/sir20165007.]

Lins, H.F., 2012, USGS Hydro-Climatic Data Network 2009 (HCDN-2009): U.S. Geological Survey Fact Sheet 2012-3047, 4 p. [Also available at https://pubs.usgs.gov/ fs $/ 2012 / 3047 /$.

Liston, G.E., and Elder, Kelly, 2006, A distribution snow-evolution modeling system (SnowModel): Journal of Hydrometeorology, v. 7, p. 1259-1276 [Also available at https://doi. org/10.1175/JHM548.1.]

Maloney, K.O., Cole, J.C., and Schmid, Matthias, 2016, Predicting thermally stressful events in rivers with a strategy to evaluate management alternatives: River Research and Applications, v. 32, no. 7, p. 1428-1437. [Also available at https://doi.org/10.1002/rra.2998.]

Maloney, K.O., Talbert, C.B., Cole, J.C., Galbraith, H.S., Blakeslee, C.J., Hanson, Leanne, and Holmquist-Johnson, C.L., 2015, An integrated Riverine Environmental Flow Decision Support System (REFDSS) to evaluate the ecological effects of alternative flow scenarios on river ecosystems.: Fundamental and Applied Limnology/Archiv für Hydrobiologie, v. 186, no. 1-2, p. 171192. [Also available at https://doi.org/10.1127/fal/2015/0611.] 
Markstrom, S.L., Hay, L.E., and Clark, M.P., 2016, Towards simplification of hydrologic modeling-Identification of dominant processes: Hydrology and Earth System Sciences, v. 20, p. 4655-4671. [Also available at https://doi. org/10.5194/hess-20-4655-2016.]

Markstrom, S.L., Regan, R.S., Hay, L.E., Viger, R.J., Webb, R.M.T., Payn, R.A., and LaFontaine, J.H., 2015, PRMSIV, the Precipitation-Runoff Modeling System (ver. 4): U.S. Geological Survey Techniques and Methods, book 6, chap. B7, 158 p. [Also available at https://doi.org/10.3133/ tm6B7.]

Masterson, J.P., and Pope, J.P., 2016, Sustainability of groundwater supplies in the northern Atlantic Coastal Plain aquifer system: U.S. Geological Survey Fact Sheet 2016-3046, 6 p. [Also available at https://doi.org/10.3133/fs20163046.]

Masterson, J.P., Pope, J.P., Fienen, M.N., Monti, Jack, Jr., Nardi, M.R., and Finkelstein, J.S., 2016, Assessment of groundwater availability in the Northern Atlantic Coastal Plain aquifer system from Long Island, New York, to North Carolina: U.S. Geological Survey Professional Paper 1829, 76 p. [Also available at https://doi.org/10.3133/pp1829.]

Maupin, M.A., and Barber, N.L., 2005, Estimated withdrawals from principal aquifers in the United States, 2000: U.S. Geological Survey Circular 1279, 46 p. [Also available at https://pubs.usgs.gov/circ/2005/1279/.]

Maupin, M.A., Kenny, J.F., Hutson, S.S., Lovelace, J.K., Barber, N.L., and Linsey, K.S., 2014, Estimated use of water in the United States in 2010: U.S. Geological Survey Circular 1405, 56 p. [Also available at https://doi.org/10.3133/ cir1405.]

McCoy, K.J., Yager, R.M., Nelms, D.L., Ladd, D.E., Monti, Jack, Jr., and Kozar, M.D., 2015, Hydrologic budget and conditions of Permian, Pennsylvanian, and Mississippian aquifers in the Appalachian Plateaus Physiographic Province: U.S. Geological Survey Scientific Investigations Report 2015-5106, 77 p. [Also available at https://doi. org/10.3133/sir20155106.]

McGuinness, C.L., 1951, The water situation in the United States with special reference to ground water: U.S. Geological Survey Circular 114, 127 p. [Also available at https:// pubs.er.usgs.gov/publication/cir114.]

McGuinness, C.L., 1963, The role of ground water in the national water situation: U.S. Geological Survey WaterSupply Paper 1800, 1121 p., 4 pl. [Also available at https:// pubs.er.usgs.gov/publication/wsp1800.]

Meinzer, O.E., 1923, Outline of ground-water hydrology: U.S. Geological Survey Water-Supply Paper 494, 71 p. [Also available at https://pubs.er.usgs.gov/publication/wsp494.]
Miller, M.P., Buto, S.G., Susong, D.D., and Rumsey, C.A., 2016, The importance of base flow in sustaining surface water flow in the Upper Colorado River Basin: Water Resources Research, v. 52, no. 5, p. 3547-3562. [Also available at https://doi.org/10.1002/2015WR017963.]

Miller, M.P., Johnson, H.M., Susong, D.D., and Wolock, D.M., 2015, A new approach for continuous estimation of baseflow using discrete water quality data-Method description and comparison with baseflow estimates from two existing approaches: Journal of Hydrology, v. 522, p. 203-210. [Also available at https://water.usgs.gov/watercensus/file/ Miller-et-al-2015.pdf.]

Miller, M.P, Susong, D.D., Shope, C.L., Heilweil, V.M., and Stolp, B.J., 2014, Continuous estimation of baseflow in snowmelt-dominated streams and rivers in the Upper Colorado River Basin-A chemical hydrograph separation approach: Water Resources Research, v. 50, no. 8, p. 6986-6999. [Also available at https://doi. org/10.1002/2013WR014939.]

Milly, P.C.D., Betancourt, Julio, Falkenmark, Malin, Hirsch, R.M., Kundzewicz, Z.W., Lettenmaier, D.P., and Stouffer, R.J., 2008, Climate change-Stationarity is dead-Whither water management?: Science, v. 319, no. 5863, p. 573-574. [Also available at https://doi.org/10.1126/science.1151915.]

Mooty, W.S., and Jeffcoat, H.H., 1986, Inventory of interbasin transfer of water in the Eastern United States: U.S. Geological Survey Open-File Report 86-148, 47 p. [Also available at https://pubs.er.usgs.gov/publication/ofr86148.]

Morway, E.D., Niswonger, R.G., and Triana, Enrique, 2016, Toward improved simulation of river operations through integration with a hydrologic model: Environmental Modelling \& Software, v. 82, p. 255-274. [Also available at https://doi.org/10.1016/j.envsoft.2016.04.018.]

National Oceanic and Atmospheric Administration, National Centers for Environmental Information, 2017, Climate at a glance - Time series, U.S., Palmer Drought Severity Index (PDSI): accessed September 22, 2017, at http://www.ncdc. noaa.gov/cag/.

National Science and Technology Council, Committee on Environment and Natural Resources, Subcommittee on Water Availability and Quality, 2007, A strategy for Federal science and technology to support water availability and quality in the United States: National Science and Technology Council, Committee on Environment and Natural Resources, Subcommittee on Water Availability and Quality, 35 p. [Also available at http://niwr.info/application/ files/2914/7204/0871/Fed_ST_Strategy_for_Water_907_FINAL.pdf.] 
Nelms, D.L., Messinger, Terrence, and McCoy, K.J., 2015, Annual and average estimates of water-budget components based on hydrograph separation and PRISM precipitation for gaged basins in the Appalachian Plateaus Region, 1900-2011: U.S. Geological Survey Data Series 944, 10 p. [Also available at https://doi.org/10.3133/ds944.]

Nelson, Jake, Blodgett, David, and Ames, Daniel, 2017, Open hydrology courseware using the United States Geological Survey's National Water Census Data Portal: Open Water Journal, v. 5, no. 1, accessed February 1, 2018, at https:// scholarsarchive.byu.edu/openwater/.

Niswonger, R.G., Morway, E.D., Triana, Enrique, and Huntington, J.L., 2017, Managed aquifer recharge through offseason irrigation in agricultural regions: Water Resources Research, v. 53, no. 8, p. 6970-6992. [Also available at https://doi.org/10.1002/2017WR020458.]

Painter, J.A., Torak, L.J., and Jones, J.W., 2015, Evaluation and comparison of methods to estimate irrigation withdrawal for the National Water Census Focus Area Study of the Apalachicola-Chattahoochee-Flint River Basin in southwestern Georgia: U.S. Geological Survey Scientific Investigations Report 2015-5118, 32 p. [Also available at https://doi.org/10.3133/sir20155118.]

Peterson, J.T., and Freeman, M.C., 2016, Integrating modeling, monitoring, and management to reduce critical uncertainties in water resource decision making: Journal of Environmental Management, v. 183, part 2, p. 361-370. [Also available at https://doi.org/10.1016/j.jenvman.2016.03.015.]

Petsch, H.E., Jr., 1985, Inventory of interbasin transfers of water in the western conterminous United States: U.S. Geological Survey Open-File Report 85-166, 45 p. [Also available at https://pubs.er.usgs.gov/publication/ofr85166.]

Poff, N.L., 1996, A hydrogeography of unregulated streams in the United States and an examination of scale-dependence in some hydrological descriptors: Freshwater Biology, v. 36, no. 1, p. 71-91. [Also available at https://doi.org/10.1046/ j.1365-2427.1996.00073.x.]

Poff, N.L., Richter, B.D., Arthington, A.H., Bunn, S.E., Naiman, R.J., Kendy, Eloise, Acreman, Mike, Apse, Colin, Bledsoe, B.P., Freeman, M.C., Henriksen, James, Jacobson, R.B., Kennen, J.G., Meritt, D.M., O'Keeffe, J.H., Olden, J.D., Rogers, Kevin, Tharme, R.E., and Warner, Andrew, 2010, The Ecological Limits of Hydrologic Alteration (ELOHA) - A new framework for developing regional environmental flow standards: Freshwater Biology, v. 55, no. 1, p. 147-170. [Also available at https://doi.org/10.1111/ j.1365-2427.2009.02204.x.]
Price, C.V., and Maupin, M.A., 2014, Documentation for the U.S. Geological Survey Public-Supply Database (PSDB) A database of permitted public-supply wells, surface-water intakes, and systems in the United States: U.S. Geological Survey Open-File Report 2014-1212, 22 p. [Also available at https://doi.org/10.3133/ofr20141212.]

Regan, R.S., and LaFontaine, J.H., 2017, Documentation of the dynamic parameter, water-use, stream and lake flow routing, and two summary output modules and updates to surface-depression storage simulation and initial conditions specification options with the Precipitation-Runoff Modeling System (PRMS): U.S. Geological Survey Techniques and Methods, book 6, chap. B8, 60 p. [Also available at https://doi.org/10.3133/tm6B8.]

Regan, R.S., Markstrom, S.L., Hay, L.E., Viger, R.J., Norton, P.A., Driscoll, J.M., and LaFontaine, J.H., 2018, Description of the National Hydrologic Model for use with the Precipitation-Runoff Modeling System (PRMS): U.S. Geological Survey Techniques and Methods, book 6, chap B9, 38 p. [Also available at https://doi.org/10.3133/tm6B9.]

Reilly, T.E., Dennehy, K.F., Alley, W.M., and Cunningham, W.L., 2008, Ground-water availability in the United States: U.S. Geological Survey Circular 1323, 70 p. [Also available at https://pubs.usgs.gov/circ/1323/.]

Rumsey, C.A., Miller, M.P., Susong, D.D., Tillman, F.D., and Anning, D.W., 2015, Regional scale estimates of baseflow and factors influencing baseflow in the Upper Colorado River Basin: Journal of Hydrology — Regional Studies, v. 4, part B, p. 91-107 [Also available at https://doi. org/10.1016/j.ejrh.2015.04.008.]

Savoca, M.E., Senay, G.B., Maupin, M.A., Kenny, J.F., and Perry, C.A., 2013, Actual evapotranspiration modeling using the operational Simplified Surface Energy Balance (SSEBop) approach: U.S. Geological Survey Scientific Investigations Report 2013-5126, 16 p. [Also available at https://pubs.usgs.gov/sir/2013/5126.]

Senay, G.B., Bohms, Stefanie, Singh, R.K., Gowda, P.H., Velpuri, N.M., Alemu, Henok, and Verdin, J.P., 2013, Operational evapotranspiration mapping using remote sensing and weather datasets - A new parameterization for the SSEB approach: Journal of the American Water Resources Association, v. 49, no. 3, p. 577-591. [Also available at https:// doi.org/10.1111/jawr.12057.]

Senay, G.B., Friedrichs, M.O., Singh, R.K., and Velpuri, N.M., 2016. Evaluating Landsat 8 evapotranspiration for water use mapping in the Colorado River Basin: Remote Sensing of Environment, v. 185, p. 171-185. [Also available at https:// doi.org/10.1016/j.rse.2015.12.043.] 
Sexstone, G.A., Clow, D.W., Stannard, D.I., and Fassnacht, S.R., 2016, Comparison of methods for quantifying surface sublimation over seasonally snow-covered terrain: Hydrological Processes, v. 30, no. 19, p. 3373-3389. [Also available at https://doi.org/10.1002/hyp.10864.]

Slack, J.R., and Landwehr, J.M., 1992, Hydro-Climatic Data Network-A U.S. Geological Survey streamflow data set for the United States for the study of climate variations, 1874-1988: U.S. Geological Survey Open-File Report 92-129, accessed September 29, 2017, at https://pubs.usgs. gov/of/1992/ofr92-129/.

Solder, J.E., Stolp, B.J., Heilweil, V.M., and Susong, D.D., 2016, Characterization of mean transit time at large springs in the Upper Colorado River Basin, USA-A tool for assessing groundwater discharge vulnerability: Hydrogeology Journal, v. 24, p. 2017-2033. [Also available at https:// doi.org/10.1007/s10040-016-1440-9.]

Solley, W.B., Pierce, R.R., and Perlman, H.A., 1998, Estimated use of water in the United States in 1995: U.S. Geological Survey Circular 1200, 71 p. [Also available at https://pubs.er.usgs.gov/publication/cir1200.]

Stanton, J.S., Anning, D.W., Brown, C.J., Moore, R.B., McGuire, V.L., Qi, S.L., Harris, A.C., Dennehy, K.F., McMahon, P.B., Degnan, J.R., and Böhlke, J.K., 2017, Brackish groundwater in the United States: U.S. Geological Survey Professional Paper 1833, 185 p. [Also available at https://doi.org/10.3133/pp1833.]

Stanton, J.S., Qi, S.L., Ryter, D.W., Falk, S.E., Houston, N.A., Peterson, S.M., Westenbroek, S.M., and Christenson, S.C., 2011, Selected approaches to estimate water-budget components of the High Plains, 1940 through 1949 and 2000 through 2009: U.S. Geological Survey Scientific Investigations Report 2011-5183, 79 p. [Also available at https:// pubs.usgs.gov/sir/2011/5183/.]

Stanton, J.S., Ryter, D.W., and Peterson, S.M., 2013, Effects of linking a soil-water-balance model with a groundwater-flow model: Groundwater, v. 51, no. 4, p. 613-622. [Also available at https://doi.org/10.1111/j.1745-6584.2012.01000.x.]

Stewart, I.T., Cayan, D.R., and Dettinger, M.D., 2005, Changes toward earlier streamflow timing across western North America: Journal of Climate, v. 18, p. 1136-1155. [Also available at https://doi.org/10.1175/JCLI3321.1.]

Stuckey, M.H., 2016, Estimation of daily mean streamflow for ungaged stream locations in the Delaware River Basin, water years 1960-2010: U.S. Geological Survey Scientific Investigations Report 2015-5157, 42 p. [Also available at https://doi.org/10.3133/sir20155157.]
Stuckey, M.H.., and Ulrich, J.E., 2016, User's guide for the Delaware River Basin Streamflow Estimator Tool (DRB-SET): U.S. Geological Survey Open-File Report 2015-1192, 6 p. [Also available at https://doi.org/10.3133/ ofr20151192.]

Sun, R.J., and Johnston, R.H., 1994, Regional Aquifer-System Analysis Program of the U.S. Geological Survey, 19781992: U.S. Geological Survey Circular 1099, 126 p. [Also available at https://pubs.er.usgs.gov/publication/cir1099.]

Taggart, B.E., 2004, Cooperative Water Program-A partnership in the Nation's Water-Resources Program: U.S. Geological Survey Fact Sheet 2004-3068, 2 p. [Also available at https://pubs.usgs.gov/fs/2004/3068/.]

Talbert, Colin, Maloney, K.O., Holmquist-Johnson, C.L., and Hanson, Leanne, 2014, User's manual for the Upper Delaware River Riverine Environmental Flow Decision Support System (REFDSS) (ver. 1.1.2): U.S. Geological Survey Open-File Report 2014-1183, 23 p. [Also available at https://doi.org/10.3133/ofr20141183.]

U.S. Geological Survey, 2007, Facing tomorrow's challenges - U.S. Geological Survey science in the decade 2007-2017: U.S. Geological Survey Circular 1309, 70 p. [Also available at https://pubs.usgs.gov/circ/2007/1309/.]

U.S. Geological Survey, 2016, Public access to results of federally funded research at the U.S. Geological SurveyScholarly publications and digital data: U.S. Geological Survey, 22 p., accessed January 8, 2016, at https://www2. usgs.gov/quality_integrity/open_access/downloads/USGSPublicAccessPlan-APPROVED-v1.03.pdf.

U.S. Geological Survey, 2017a, Coastal Carolinas Focus Area Study: accessed April 27, 2018, at https://webapps.usgs. gov/watercensus/coastalcarolinas_fas/.

U.S. Geological Survey, 2017b, Red River Basin Focus Area Study: accessed April 27, 2018, at https://webapps.usgs. gov/watercensus/redriver_fas/.

U.S. Geological Survey, 2017c, Upper Rio Grande River Basin Focus Area Study: accessed April 27, 2018, at https:// webapps.usgs.gov/watercensus/riogrande_fas/.

U.S. Geological Survey, 2017d, U.S. Energy Balance Model Output: U.S. Geological Survey web page, accessed September 29, 2017, at https://earlywarning.usgs.gov/useta/ etaseasonal.php.

U.S. Geological Survey, 2017e, USGS GeoLog Locator: accessed April 10, 2018, at https://webapps.usgs.gov/ GeoLogLocator/\#!/.

U.S. Geological Survey, 2017f, Water Census Data Portal: U.S. Geological Survey web page, accessed April 10, 2018, at https://cida.usgs.gov/nwc/\#!waterbudget/ achuc/070900020703. 
Van Beusekom, A.E., and Viger, R.J., 2016, A glacier runoff extension to the Precipitation Runoff Modeling System: Journal of Geophysical Research-Earth Surface, v. 121, no. 11, p. 2001-2021. [Also available at https://doi. org/10.1002/2015JF003789.]

Velpuri, N.M., Senay, G.B., Singh, R.K., Bohms, Stefanie, and Verdin, J.P., 2013, A comprehensive evaluation of two MODIS evapotranspiration products over the conterminous United States-Using point and gridded FLUXNET and water balance ET: Remote Sensing of Environment, v. 139, p. 35-49. [Also available at https://doi.org/10.1016/j. rse.2013.07.013.]

Viger, R.J., 2014, Preliminary spatial parameters for PRMS based on the Geospatial Fabric, NLCD2001 and SSURGO: U.S. Geological Survey data release, accessed February 1, 2018, at https://doi.org/doi:10.5066/F7WM1BF7.

Viger, R.J., and Bock, Andrew, 2014, GIS Features of the Geospatial Fabric for National Hydrologic Modeling: U.S. Geological Survey data release, accessed February 1, 2018, at https://doi.org/doi:10.5066/F7542KMD.

Wallace, C.S.A., Thenkabail, Prasad, Rodriguez, J.R., and Brown, M.K., 2017, Fallow-land Algorithm based on Neighborhood and Temporal Anomalies (FANTA) to map planted versus fallowed croplands using MODIS data to assist in drought studies leading to water and food security assessments: GIScience \& Remote Sensing, v. 54, no. 2, p. 258-282. [Also available at https://doi.org/10.1080/1548 1603.2017.1290913.]

Welter, D.E., White, J.T., Hunt, R.J., and Doherty, J.E., 2015, Approaches in highly parameterized inversion-PEST++ (ver. 3), a Parameter ESTimation and uncertainty analysis software suite optimized for large environmental models: U.S. Geological Survey Techniques and Methods, book 7, chap. C12, 54 p. [Also available at https://doi.org/10.3133/ tm7C12.]

Westenbroek, S.M., Kelson, V.A., Dripps, W.R., Hunt, R.J., and Bradbury, K.R., 2010, SWB-A modified Thornthwaite-Mather Soil-Water-Balance code for estimating groundwater recharge: U.S. Geological Survey Techniques and Methods, book 6, chap. A31, 60 p. [Also available at https://pubs.usgs.gov/tm/tm6-a31/.]

Wheeler, Kit, Wenger, S.J., and Freeman, M.C., 2017, States and rates: Complementary approaches to developing flowecology relationships: Freshwater Biology, v. 00 (Special Issue), p. 1-11. [Also available at https://doi.org/10.1111/ fwb.13001.]
Wheeler, Kit, Wenger, S.J., Walsh, S.J., Martin, Z.P., Jelks, H.L., and Freeman, M.C., 2018, Stream fish colonization but not persistence varies regionally across a large North American river basin: Biological Conservation, v. 223, p. 1-10, [Also available at https://doi.org/10.1016/j.biocon.2018.04.023.]

White, J.T., Fienen, M.N., Barlow, P.M., and Welter, D.E., 2018, A tool for efficient, model-independent management optimization under uncertainty: Environmental Modelling \& Software, v. 100, p. 213-221. [Also available at https:// doi.org/10.1016/j.envsoft.2017.11.019.]

White, J.T., Fienen, M.N., and Doherty, J.E., 2016, A python framework for environmental model uncertainty analysis: Environmental Modelling \& Software, v. 85, p. 217-228. [Also available at https://doi.org/10.1016/j. envsoft.2016.08.017.]

Williamson, T.N., and Lant, J.G., 2015, User manuals for the Delaware River Basin Water Availability Tool for Environmental Resources (DRB-WATER) and associated WATER application utilities: U.S. Geological Survey Open-File Report 2015-1196, 32 p. [Also available at https://doi. org/10.3133/ofr20151196.]

Williamson, T.N., Lant, J.G., Claggett, Peter, Nystrom, E.A., Milly, P.C.D., Nelson, H.L., Hoffman, S.A., Colarullo, S.J., and Fischer, J.M., 2015, Summary of hydrologic modeling for the Delaware River Basin using the Water Availability Tool for Environmental Resources (WATER): U.S. Geological Survey Scientific Investigations Report 2015-5143, 68 p. [Also available at https://doi.org/10.3133/ sir20155143.] 


\section{Appendix 1. Geographic Focus Area Study Publications}

\section{Apalachicola-Chattahoochee-Flint River Basin}

Clarke, J.S., and Painter, J.A., 2014, Influence of septic systems on stream base flow in the Apalachicola-Chattahoochee-Flint River Basin near Metropolitan Atlanta, Georgia, 2012: U.S. Geological Survey Scientific Investigations Report 2014-5144, 68 p. [Also available at https:/doi. org/10.3133/sir20145144.]

Freeman, M.C., Buell, G.R., Hay, L.E., Hughes, W.B., Jacobson, R.B., Jones, J.W., Jones, S.A., LaFontaine, J.H., Odom, K.R., Peterson, J.T., Riley, J.W., Schindler, J.S., Shea, Colin, and Weaver, J.D., 2013, Linking river management to species conservation using dynamic landscapescale models: River Research and Applications, v. 29, p. 906-918. [Also available at http://onlinelibrary.wiley. com/doi/10.1002/rra.2575/full.]

Gordon, D.W., Peck, M.F., and Painter, J.A., 2012, Hydrologic and water-quality conditions in the lower ApalachicolaChattahoochee-Flint and parts of the Aucilla-SuwaneeOchlockonee River basins in Georgia and adjacent parts of Florida and Alabama during drought conditions, July 2011: U.S. Geological Survey Scientific Investigations Report 2012-5179, 69 p., 1 sheet. [Also available at http://pubs. usgs.gov/sir/2012/5179/.]

Jones, L.E., Painter, Jaime, LaFontaine, Jacob, Sepulveda, Nicasio, and Sifuentes, D.F., 2017, Groundwater-flow budget for the lower Apalachicola-Chattahoochee-Flint River Basin in southwestern Georgia and parts of Florida and Alabama, 2008-12: U.S. Geological Survey Scientific Investigations Report 2017-5141, 76 p. [Also available at https://doi.org/10.3133/sir20175141.]

LaFontaine, J.H., Jones, L.E., and Painter, J.A., 2017, Simulations of hydrologic response in the Apalachicola-Chattahoochee-Flint River Basin, Southeastern United States: U.S. Geological Survey Scientific Investigations Report 20175133, 112 p. [Also available at https://doi.org/10.3133/ sir20175133.]

Lawrence, S.J., 2016, Water use in the Apalachicola-Chattahoochee-Flint River Basin, Alabama, Florida, and Georgia, 2010, and water-use trends, 1985-2010: U.S. Geological Survey Scientific Investigations Report 2016-5007, 72 p. [Also available at https://doi.org/10.3133/sir20165007.]
Painter, J.A., Torak, L.J., and Jones, J.W., 2015, Evaluation and comparison of methods to estimate irrigation withdrawal for the National Water Census Focus Area Study of the Apalachicola-Chattahoochee-Flint River Basin in southwestern Georgia: U.S. Geological Survey Scientific Investigations Report 2015-5118, 32 p. [Also available at https://doi.org/10.3133/sir20155118.]

Peterson, J.T., and Freeman, M.C., 2016, Integrating modeling, monitoring, and management to reduce critical uncertainties in water resource decision making: Journal of Environmental Management, v. 183, p. 361-370. [Also available at https://doi.org/10.1016/j.jenvman.2016.03.015.]

Regan, R.S., and LaFontaine, J.H., 2017, Documentation of the dynamic parameter, water-use, stream and lake flow routing, and two summary output modules and updates to surface-depression storage simulation and initial conditions specification options with the Precipitation-Runoff Modeling System (PRMS): U.S. Geological Survey Techniques and Methods, book 6, chap. B8, 60 p. [Also available at https://doi.org/10.3133/tm6B8.]

\section{Colorado River Basin}

Clow, D.W., 2010, Changes in the timing of snowmelt and streamflow in Colorado-A response to recent warming: Journal of Climate, v. 23, no. 9, p. 2293-2306. [Also available at https://doi.org/10.1175/2009jcli2951.1.]

Clow, D.W., Nanus, Leora, Verdin, K.L., and Schmidt, Jeffrey, 2012, Evaluation of SNODAS snow depth and snow water equivalent estimates for the Colorado Rocky Mountains, USA: Hydrological Processes, v. 26, no. 17, p. 2583-2591. [Also available at https://doi.org/10.1002/hyp.9385.]

Clow, D.W., Williams, M.W., and Schuster, P.F., 2016, Increasing aeolian dust deposition to snowpacks in the Rocky Mountains inferred from snowpack, wet deposition, and aerosol chemistry: Atmospheric Environment, v. 146, p. 183-194. [Also available at https://doi.org/10.1016/j. atmosenv.2016.06.076.]

Liston, G.E., and Elder, Kelly, 2006, A distribution snow-evolution modeling system (SnowModel): Journal of Hydrometeorology, v. 7, p. 1259-1276. [Also available at https://doi. org/10.1175/JHM548.1.] 
Miller, M.P., Buto, S.G., Susong, D.D., and Rumsey, C.A., 2016, The importance of base flow in sustaining surface water flow in the Upper Colorado River Basin: Water Resources Research, v. 52, p. 3547-3562. [Also available at http://onlinelibrary.wiley.com/doi/10.1002/2015WR017963/ full.]

Miller, M.P., Johnson, H.M., Susong, D.D., and Wolock, D.M., 2015, A new approach for continuous estimation of baseflow using discrete water quality data-Method description and comparison with baseflow estimates from two existing approaches: Journal of Hydrology, v. 522, p. 203-210. [Also available at http://dx.doi.org/10.1016/j. jhydrol.2014.12.039.]

Miller, M.P, Susong, D.D., Shope, C.L., Heilweil, V.M., and Stolp, B.J., 2014, Continuous estimation of baseflow in snowmelt-dominated streams and rivers in the Upper Colorado River Basin - A chemical hydrograph separation approach: Water Resources Research, v. 50, p. 6986-6999. [Also available at http://onlinelibrary.wiley.com/ doi/10.1002/2013WR014939/full.]

Rumsey, C.A., Miller, M.P., Susong, D.D., Tillman, F.D., and Anning, D.W., 2015, Regional scale estimates of baseflow and factors influencing baseflow in the Upper Colorado River Basin: Journal of Hydrology—Regional Studies, v. 4, p. 91-107. [Also available at https://doi.org/10.1016/j. ejrh.2015.04.008.]

Sexstone, G.A., Clow, D.W., Stannard, D.I., and Fassnacht, S.R., 2016, Comparison of methods for quantifying surface sublimation over seasonally snow-covered terrain: Hydrological Processes, v. 30, no. 19, p. 3373-3389. [Also available at https://doi.org/10.1002/hyp.10864.]

Solder, J.E., Stolp, B.J., Heilweil, V.M., and Susong, D.D., 2016, Characterization of mean transit time at large springs in the Upper Colorado River Basin, USA-A tool for assessing groundwater discharge vulnerability: Hydrogeology Journal, v. 24, p. 2017-2033. [Also available at https:// doi.org/10.1007/s10040-016-1440-9.]

\section{Delaware River Basin}

Cole, J.C., Maloney, K.O., Schmid, Matthias, and McKenna, J.E., 2014. Developing and testing temperature models for regulated systems - A case study on the upper Delaware River: Journal of Hydrology, v. 519, p. 588-598. [Also available at https://doi.org/10.1016/j.jhydrol.2014.07.058.]

Hutson, S.S., Linsey, K.S., Ludlow, R.A., Reyes, Betzaida, and Shourds, J.L., 2015, Estimated use of water in the Delaware River Basin in Delaware, New Jersey, New York, and Pennsylvania, 2010: U.S. Geological Survey Scientific Investigations Report 2015-5142, 76 p. [Also available at https://dx.doi.org/10.3133/sir20155142.]
Maloney, K.O., Cole, J.C., and Schmid, Matthias, 2016, Predicting thermally stressful events in rivers with a strategy to evaluate management alternatives: River Research and Applications, v. 32, no. 7, p. 1428-1437. [Also available at https://doi.org/10.1002/rra.2998.]

Maloney, K.O., Talbert, C.B., Cole, J.C., Galbraith, H.S., Blakeslee, C.J., Hanson, Leanne, and Holmquist-Johnson, C.L., 2015. An integrated riverine environmental flow decision support system (REFDSS) to evaluate the ecological effects of alternative flow scenarios on river ecosystems: Fundamental and Applied Limnology/Archiv für Hydrobiologie, v. 186, p. 171-192. [Also available at https://doi. org $/ 10.1127 /$ fal $/ 2015 / 0611$.

Stuckey, M.H., 2016, Estimation of daily mean streamflow for ungaged stream locations in the Delaware River Basin, water years 1960-2010: U.S. Geological Survey Scientific Investigations Report 2015-5157, 42 p. [Also available at https://doi.org/10.3133/sir20155157.]

Stuckey, M.H., and Ulrich, J.E., 2016, User's guide for the Delaware River Basin Streamflow Estimator Tool (DRB-SET): U.S. Geological Survey Open-File Report 2015-1192, 6 p. [Also available at https://doi.org/10.3133/ ofr20151192.]

Talbert, Colin, Maloney, K.O., Holmquist-Johnson, C.L., and Hanson, Leanne, 2014, User's manual for the upper Delaware River riverine environmental flow decision support system (REFDSS) (ver. 1.1.2): U.S. Geological Survey Open-File Report 2014-1183, 23 p. [Also available at https://doi.org/10.3133/ofr20141183.]

Williamson, T.N., Lant, J.G., Claggett, P.R., Nystrom, E.A., Milly, P.C.D., Nelson, H.L., Hoffman, S.A., Colarullo, S.J., and Fischer, J.M., 2015, Summary of hydrologic modeling for the Delaware River Basin using the Water Availability Tool for Environmental Resources (WATER): U.S. Geological Survey Scientific Investigations Report 2015-5143, 68 p. [Also available at https://doi.org/10.3133/ sir20155143.]

Williamson, T.N., Nystrom, E.A., and Milly, P.C.D., 2016, Sensitivity of the projected hydroclimatic environment of the Delaware River basin to formulation of potential evapotranspiration: Climatic Change, v. 139, p. 215-228. [Also available at https://doi.org/10.1007/s10584-016-1782-2.] 


\section{Appendix 2. Regional Groundwater Availability Study Publications}

\section{Columbia Plateau Regional Aquifer System}

Ely, D.M., Burns, E.R., Morgan, D.S., and Vaccaro, J.J., 2014, Numerical simulation of groundwater flow in the Columbia Plateau regional aquifer system, Idaho, Oregon, and Washington (ver. 1.1, January 2015): U.S. Geological Survey Scientific Investigations Report 2014-5127, 90 p. [Also available at https://doi.org/10.3133/sir20145127.]

Kahle, S.C., and Vaccaro, J.J., 2015, Groundwater resources of the Columbia Plateau regional aquifer system: U.S. Geological Survey Fact Sheet 2015-3063, 6 p. [Also available at https://doi.org/10.3133/fs20153063.]

Vaccaro, J.J., Kahle, S.C., Ely, D.M., Burns, E.R., Snyder, D.T, Haynes, J.V., Olsen, T.D., Welch, W.B., and Morgan, D.S., 2015, Groundwater availability of the Columbia Plateau regional aquifer system, Washington, Oregon, and Idaho: U.S. Geological Survey Professional Paper 1817, 87 p. [Also available at https://doi.org/10.3133/pp1817.]

\section{High Plains Aquifers}

Houston, N.A., Gonzales-Bradford, S.L., Flynn, A.T., Qi, S.L., Peterson, S.M., Stanton, J.S., Ryter, D.W., Sohl, T.L., and Senay, G.B., 2013, Geodatabase compilation of hydrogeologic, remote sensing, and water-budget-component data for the High Plains aquifer, 2011: U.S. Geological Survey Data Series 777, 12 p. [Also available at https://pubs.usgs.gov/ ds/777/.]

Peterson, Steven, 2016, Base of aquifer contours for the Northern High Plains aquifer: U.S. Geological Survey data release, accessed September 29, 2017, at https://doi. org/10.5066/F7K072C9.

Peterson, S.M., Flynn, A.T., and Traylor, J.P., 2016a, Groundwater-flow model of the Northern High Plains aquifer in Colorado, Kansas, Nebraska, South Dakota, and Wyoming: U.S. Geological Survey Scientific Investigations Report 2016-5153, 88 p. [Also available at https://doi.org/10.3133/ sir20165153.]

Peterson, S.M., Flynn, A.T., and Traylor, J.P., 2016b, MODFLOW-NWT groundwater flow model used to evaluate conditions in the Northern High Plains aquifer in Colorado, Kansas, Nebraska, South Dakota, and Wyoming: U.S. Geological Survey data release, accessed September 29, 2017 , at https://doi.org/10.5066/F7JS9NKD.

\section{Floridan Aquifer System}

Kuniansky, E.L., 2016, Simulating groundwater flow in karst aquifers with distributed parameter models - Comparison of porous-equivalent media and hybrid flow approaches: U.S. Geological Survey Scientific Investigations Report 2016-5116, 14 p. [Also available at https://doi.org/10.3133/ sir20165116.]

Reyes, Betzaida, 2017, Daily weather data (precipitation, minimum and maximum air temperatures) of Florida, parts of Georgia, Alabama, and South Carolina, 1895-1915: U.S. Geological Survey data release, accessed February 1, 2018, at https://doi.org/10.5066/F7639MT4.

Williams, L.J., and Dixon, J.F., 2015, Digital surfaces and thicknesses of selected hydrogeologic units of the Floridan aquifer system in Florida and parts of Georgia, Alabama, and South Carolina: U.S. Geological Survey Data Series 926, 24 p. [Also available at https://doi.org/10.3133/ds926.]

Williams, L.J., and Kuniansky, E.L., 2015, Revised hydrogeologic framework of the Floridan aquifer system in Florida and parts of Georgia, Alabama, and South Carolina: U.S. Geological Survey Professional Paper 1807, 140 p., 23 pl. [Also available at https://doi.org/10.3133/pp1807.]

Williams, L.J., Raines, J.E., and Lanning, A.E., 2013, Geophysical log database for the Floridan aquifer system and southeastern Coastal Plain aquifer system in Florida and parts of Georgia, Alabama, and South Carolina: U.S. Geological Survey Data Series 760, 11 p. [Also available at http://pubs.usgs.gov/ds/760.]

\section{Northern Atlantic Coastal Plain Aquifer System}

Charles, E.G., 2016, Regional chloride distribution in the Northern Atlantic Coastal Plain aquifer system from Long Island, New York, to North Carolina: U.S. Geological Survey Scientific Investigations Report 2016-5034, 37 p., 2 app. [Also available at https://doi.org/10.3133/ $\operatorname{sir} 20165034$.

Eggleston, Jack, and Pope, Jason, 2013, Land subsidence and relative sea-level rise in the southern Chesapeake Bay region: U.S. Geological Survey Circular 1392, 30 p. [Also available at https://doi.org/10.3133/cir1392.] 
Finkelstein, J.S., and Nardi, M.R., 2015, Geospatial compilation and digital map of center-pivot irrigated areas in the mid-Atlantic region, United States: U.S. Geological Survey Data Series 932, accessed May 25, 2016, at https://doi. org/10.3133/ds932.

Masterson, J.P., and Pope, J.P., 2016, Sustainability of groundwater supplies in the Northern Atlantic Coastal Plain aquifer system: U.S. Geological Survey Fact Sheet 2016-3046, 6 p. [Also available at https://doi.org/10.3133/fs20163046.]

Masterson, J.P., Pope, J.P., Fienen, M.N., Monti, Jack, Jr., Nardi, M.R., and Finkelstein, J.S., 2016a, Assessment of groundwater availability in the Northern Atlantic Coastal Plain aquifer system from Long Island, New York, to North Carolina: U.S. Geological Survey Professional Paper 1829, 76 p. [Also available at https://doi.org/10.3133/pp1829.]

Masterson, J.P., Pope, J.P., Fienen, M.N., Monti, Jack, Jr., Nardi, M.R., and Finkelstein, J.S., 2016b, Documentation of a groundwater flow model developed to assess groundwater availability in the Northern Atlantic Coastal Plain aquifer system from Long Island, New York, to North Carolina: U.S. Geological Survey Scientific Investigations Report 2016-5076, 70 p. [Also available at https://doi.org/10.3133/ sir20165076.]

Masterson, J.P., Pope, J.P., Monti, Jack, Jr., Nardi, M.R., Finkelstein, J.S., and McCoy, K.J., 2013, Hydrogeology and hydrologic conditions of the Northern Atlantic Coastal Plain aquifer system from Long Island, New York, to North Carolina: U.S. Geological Survey Scientific Investigations Report 2013-5133, 76 p. [Also available at https://doi. org/10.3133/sir20135133.]

Pope, J.P., Andreasen, D.C., McFarland, E.R., and Watt, M.K., 2016, Digital elevations and extents of regional hydrogeologic units in the Northern Atlantic Coastal Plain aquifer system from Long Island, New York, to North Carolina: U.S. Geological Survey Data Series 996, 28 p. [Also available at https://doi.org/10.3133/ds996.]

\section{Glacial Aquifer System}

Bayless, E.R., Arihood, L.D., Reeves, H.W., Sperl, B.J.S., Qi, S.L., Stipe, V.E., and Bunch. A.R., 2017, Maps and grids of hydrogeologic information created from standardized water-well drillers' records of the glaciated United States: U.S. Geological Survey Scientific Investigations Report 2015-5105, 34 p. [Also available at https://doi.org/10.3133/ sir20155105.]

Callegary, J.B., Kikuchi, C.P., Koch, J.C., Lilly, M.R., and Leake, S.L., 2013, Review-Groundwater in Alaska (USA): Hydrogeology Journal, v. 21, no. 1, p. 25 (abstract). [Also available at https://doi.org/10.1007/s10040-012-0940-5.]
Feinstein, D.T., Fienen, M.N., Reeves, H.W., and Langevin, C.D., 2016, A semi-structured MODFLOW-USG model to evaluate local water sources to wells for decision support: Groundwater, v. 54, no. 4, p. 532-544. [Also available at https://doi.org/10.1111/gwat.12389.]

Fienen, M.N., Nolan, B.T., and Feinstein, D.T., 2016, Evaluating the sources of water to wells-Three techniques for metamodeling of a groundwater flow model: Environmental Modelling \& Software, v. 77, p. 95-107. [Also available at https://doi.org/10.1016/j.envsoft.2015.11.023.]

Fienen, M.N., Nolan, B.T., Feinstein, D.T., and Starn, J.J., 2015, Metamodels to bridge the gap between modeling and decision support: Groundwater, v. 53, no. 4, p. 511-512. [Also available at https://doi.org/10.1111/gwat.12339.]

Fienen, M.N., and Plant, Nathaniel, 2014, A cross-validation package driving Netica with Python: Environmental Modelling \& Software, v. 63, p. 14-23. [Also available at https:// doi.org/10.1016/j.envsoft.2014.09.007.]

McMahon, P.B., Böhlke, J.K., Dahm, K.G., Parkhurst, D.L., Anning, D.W., and Stanton, J.S., 2015, Chemical considerations for an updated national assessment of brackish groundwater resources: Groundwater, v. 54, no. 4, p. 464-475. [Also available at https://doi.org/10.1111/ gwat.12367.]

\section{Williston and Powder River Aquifer System}

Long, A.J., Aurand, K.R., Bednar, J.M., Davis, K.W., Mckaskey, J.D.R.G., and Thamke, J.N., 2014, Conceptual model of the uppermost principal aquifer systems in the Williston and Powder River structural basins, United States and Canada: U.S. Geological Survey Scientific Investigations Report 2014-5055, 41 p., 1 app. [Also available at https:// doi.org/10.3133/sir20145055.]

Thamke, J.N., LeCain, G.D., Ryter, D.W., Sando, Roy, and Long, A.J., 2014, Hydrogeologic framework of the uppermost principal aquifer systems in the Williston and Powder River structural basins, United States and Canada: U.S. Geological Survey Scientific Investigations Report 2014-5047, 38 p. [Also available at https://doi.org/10.3133/ sir20145047.] 


\section{Hawaii Volcanic-Rock Aquifer System}

Engott, J.A., Johnson, A.G., Bassiouni, Maoya, Izuka, S.K., and Rotzoll, Kolja, 2017, Spatially distributed groundwater recharge for 2010 land cover estimated using a water-budget model for the Island of O'ahu, Hawai'i (ver. 2.0, December 2017): U.S. Geological Survey Scientific Investigations Report 2015-5010, 49 p. [Also available at https://doi. org/10.3133/sir20155010.]

Izuka, S.K., Engott, J.A., Rotzoll, Kolja, Bassiouni, Maoya, Johnson, A.G., Miller, L.D., and Mair, Alan, 2018, Volcanic aquifers of Hawai' $\mathrm{i}$ - Hydrogeology, water budgets, and conceptual models (ver. 2.0, March 2018): U.S. Geological Survey Scientific Investigations Report 2015-5164, 158 p. [Also available at https://doi.org/10.3133/sir20155164.]

Johnson, A.G., Engott, J.A., Bassiouni, Maoya, and Rotzoll, Kolja, 2018, Spatially distributed groundwater recharge estimated using a water-budget model for the Island of Maui, Hawai i, 1978-2007 (ver. 2.0, February 2018): U.S. Geological Survey Scientific Investigations Report 2014-5168, 53 p. [Also available at https://doi.org/10.3133/ sir20145168.]

\section{Ozarks Plateaus Aquifer System}

Hays, P.D., Knierim, K.J., Breaker, B.K., Westerman, D.A., and Clark, B.R., 2016, Hydrogeology and hydrologic conditions of the Ozark Plateaus aquifer system: U.S. Geological Survey Scientific Investigations Report 2016-5137, 61 p., 2 app. [Also available at https://doi.org/10.3133/ sir20165137.]

Knierim, K.J., Nottmeier, A.M., Worland, Scott, Westerman, D.A., and Clark, B.R., 2016, Groundwater withdrawal rates from the Ozark Plateaus aquifer system, 1900 to 2010: U.S. Geological Survey data release, accessed September 29, 2017, at https://doi.org/10.5066/F7GQ6VV1.

Knierim, K.J., Nottmeier, A.M., Worland, Scott, Westerman, D.A., and Clark, B.R., 2017, Challenges for creating a site-specific groundwater-use record for the Ozark Plateaus aquifer system (central USA) from 1900 to 2010: Hydrogeology Journal, v. 25, no. 6, p. 1779-1793. [Also available at https://doi.org/10.1007/s10040-017-1593-1.]

Knierim, K.J., Wagner, D.M., Roland, V.L., and Nottmeier, A.M., 2015, Ozark Plateaus seepage run dataset, southern Missouri and northern Arkansas, 1982-2006: U.S. Geological Survey data release, accessed September 29, 2017, at https://doi.org/10.5066/F7W9577Q.
Nottmeier, A.M., 2015, Regional potentiometric surface of the Ozark aquifer in Arkansas, Kansas, Missouri, and Oklahoma, November 2014-January 2015: U.S. Geological Survey Scientific Investigations Map 3348, 1 sheet. [Also available at https://doi.org/10.3133/sim3348.]

Nottmeier, A.M., 2016, Regional potentiometric surface dataset of the Ozark aquifer in Arkansas, Kansas, Missouri, and Oklahoma, November 2014-January 2015: U.S. Geological Survey data release, accessed September 29, 2017, at https://doi.org/10.5066/F74747XS.

Turner, N.L., Knierim, K.J., and Kresse, Timothy, 2016, Sinkholes and springs of the Ozark Physiographic Province, northern Arkansas, from topographic maps: U.S. Geological Survey data release, accessed September 29, 2017, at https://doi.org/10.5066/F7XK8CNZ.

U.S. Geological Survey, 2015, Groundwater, a source to streams in the Ozark Plateaus: U.S. Geological Survey video, accessed November 9, 2017, at https:/www.youtube. com/watch?v=CTw4cfZyTMw.

Westerman, D.A., Gillip, J.A., Richards, J.M., Hays, P.D., and Clark, B.R., 2016a, Altitudes and thicknesses of hydrogeologic units of the Ozark Plateaus aquifer system in Arkansas, Kansas, Missouri, and Oklahoma: U.S. Geological Survey data release, accessed September 29, 2017, at https://doi.org/10.5066/F7HQ3X0T.

Westerman, D.A., Gillip, J.A., Richards, J.M., Hays, P.D., and Clark, B.R., 2016b, Altitudes and thicknesses of hydrogeologic units of the Ozark Plateaus aquifer system in Arkansas, Kansas, Missouri, and Oklahoma: U.S. Geological Survey Scientific Investigations Report 2016-5130, 32 p. [Also available at https://doi.org/10.3133/sir20165130.]

\section{Pennsylvanian and Mississippian Aquifer System of the Appalachian Plateaus}

Ladd, D.E., 2016, Mean-annual and mean-seasonal waterbudget estimates from a Soil-Water-Balance model of the Appalachian Plateaus, 1980 through 2011: U.S. Geological Survey data release, accessed September 29, 2017, at https://doi.org/10.5066/F7X06544.

McCoy, K.J., Yager, R.M., Nelms, D.L., Ladd, D.E., Monti, Jack, Jr., and Kozar, M.D., 2015, Hydrologic budget and conditions of Permian, Pennsylvanian, and Mississippian aquifers in the Appalachian Plateaus Physiographic Province (ver. 1.1, October 2015): U.S. Geological Survey Scientific Investigations Report 2015-5106, 77 p. [Also available at https://doi.org/10.3133/sir20155106.] 
Nelms, D.L., Messinger, Terence, and McCoy, K.J., 2015, Annual and average estimates of water-budget components based on hydrograph separation and PRISM precipitation for gaged basins in the Appalachian Plateaus region, 1900-2011: U.S. Geological Survey Data Series 944, 10 p. [Also available at https://doi.org/10.3133/ds944.]

Yager, R.M., McCoy, K.J., Voss, C.I., Sanford, W.E., and Winston, R.B., 2017, The role of uplift and erosion in the persistence of saline groundwater in the shallow subsurface: Geophysical. Research Letters, v. 44, no. 8, p. 3672-3681. [Also available at https://doi.org/10.1002/2017GL072980.]

\section{Northwest Volcanic Aquifer Study}

Burns, E.R., Gannett, M.W., Sherrod, D.R., Keith, M.K., Curtis, J.A., Bartolino, J.R., Engott, J.A., Scandella, B.P., Stern, M.A., and Flint, A.L., 2017, Geothermal implications of a refined composition-age geologic map for the volcanic terranes of southeast Oregon, northeast California, and southwest Idaho, USA: Geothermal Resources Council Transactions, v. 41. [Also available at https://pubs.er.usgs. gov/publication/70191365.]

Burns, E.R., Zhu, Yonghui, Zhan, Hongbin, Manga, Michael, Williams, C.F., Ingebritsen, S.E., and Dunham, J.B., 2017, Thermal effect of climate change on groundwater-fed ecosystems: Water Resources Research, v. 53, no. 4, p. 3341-3351. [Also available at https://doi. org/10.1002/2016WR020007.] 
For additional information, contact:

Melinda S. Dalton

Coordinator-Water Availability and Use Science Program U.S. Geological Survey 12201 Sunrise Valley Drive Reston, VA 20192

or visit our website at: https://water.usgs.gov/wausp/ 


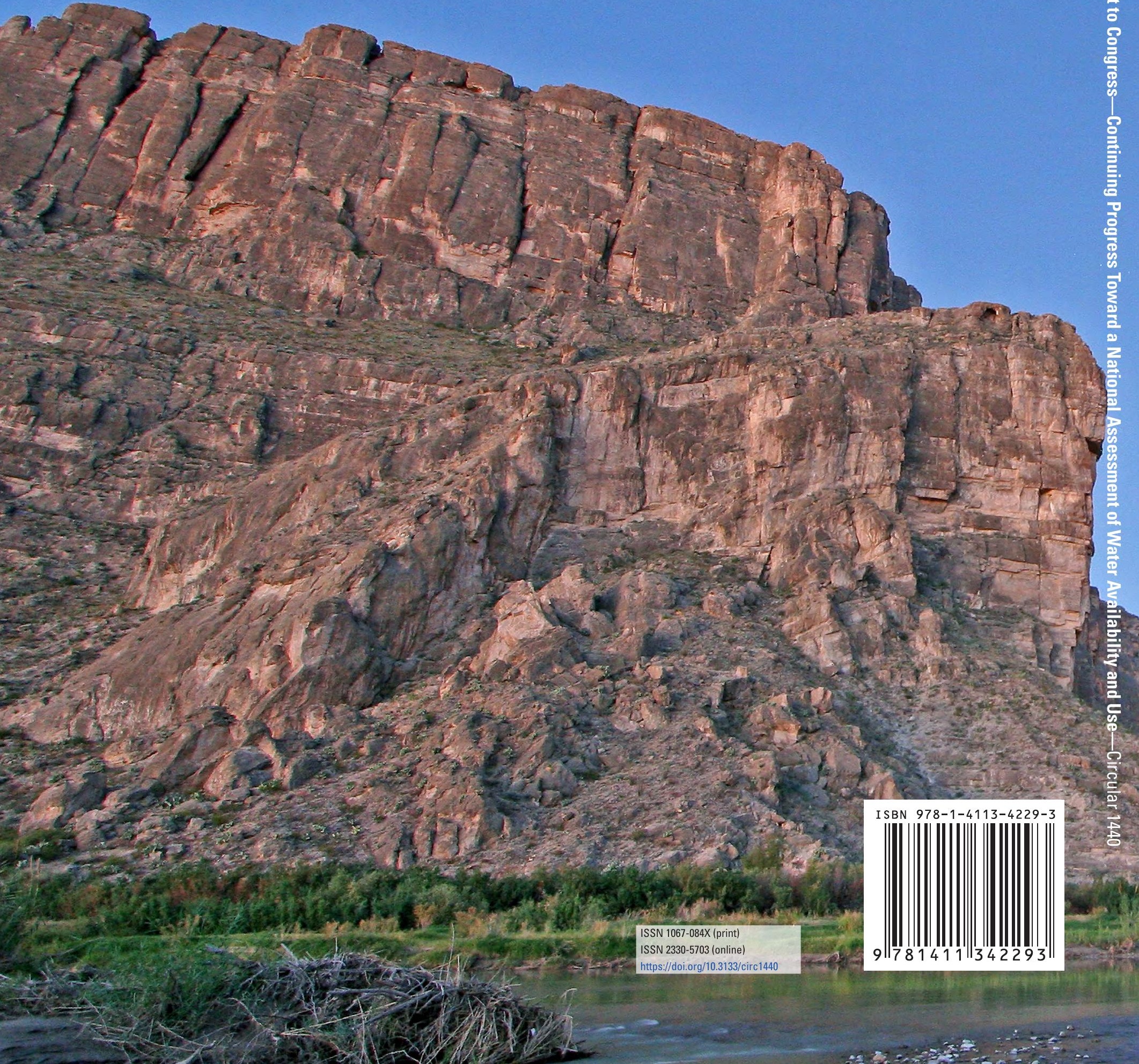

